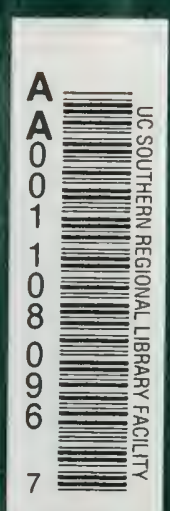




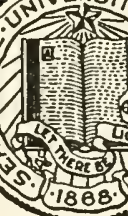

THE LIBRARY

OF

THE UNIVERSITY

OF CALIFORNIA

LOS ANGELES 


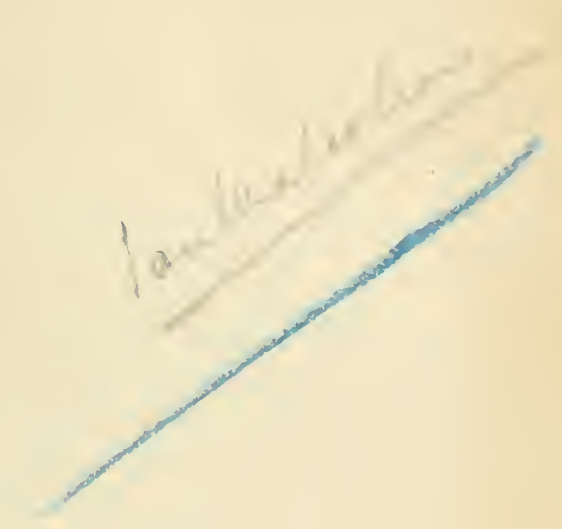





\section{MODERN IRELAND AND \\ HER AGRARIAN PROBLEM.}

BY MORITZ J. BONN.

TRANSLATED FROM THE GERMAN

BY T. W. ROLLESTON.

\section{DUBLIN :}

HODGES, FIGGIS, \& CO., LTD.

LONDON: JOHN MURRAY, ALBEMTARLE ST.

I906. 
DUBLIN :

PRINTED AT THE UNIVERSITY PRESS, BY PONSONBY \& GIBBS. 


\section{CONTENTS.}

PAGE

PREFACE

CHAPTEK

PART I.-THE IREIAND OF TO-IOAY.

os I. ExGLani's Failuke in Ireland, $(a)$ Political 7

as II. ENGLAND'S FAILURE IN IRELAND, (b) ECONOMIC i;

oc III. SOCIAL Conditions of THE PEOple 19

IV. OCCUPATIONS OF THE PEOPLE . • . 26

V. Tendencies of IRISH AgRicultukf a 32

VI. THE IRISH TENANT AND HIS HOLDING • 44

VII. THE IRISH I.ANDLORD ANI HIS ESTATE * 59

PART II.-IRISH AGRARIAN TENURE.

I. LEgislation FOR THE REFORM OF JANDLORDISM: THE LAND ACTS . . . 66

II. JEgISLATION FOR THE ABOLITION OF LANDLORDisM: ThE LAND PURChase ACTS • 92

PART III.-THE AGRARIAN REFORM OF 1903.

I. INSUFFICIENCY OF THE LAND ACTS • • 105

II. Insufficiency of THE LAND PURChase ACts 117 III. A NEW DeparturE . . . . 122

IV. The IVyndhan Land ACT: ITs Provisions 1.36

V. The IVyndhan Land ACt in Operation . 147

VI. A Peasant Proprietary, and After • 157 



\section{PREFACE.}

THE following pages are the first-fruits of studies in Irish history and Irish economics made by a Continental observer, Dr. Moritz J. Bonn. Dr. Bonn qualified himself for his task by a more or less continuous residence of several years in Ireland. He made acquaintance with its leading men of all parties; he laid the foundation of his knowledge of the conditions of modern Ireland by a thorough study of the history of the country from the Norman conquest downwards; he made himself familiar with the laws and institutions of the country by the close observation of their operation in contemporary iife, as well as by the study of official publications. His attitude is that of a foreigner, quite removed from the influences of party politics. He has wished to see things as they are-to regard Ireland (or as much of Ireland as he here deals with) from the standpoint of general European culture. Much has been written about Ireland in attack 
or in defence, in furtherance of reforms or in resistance to them; but very little has been written, as Dr. Bonn writes, from the point of view of pure sociology. He gives us dry light on Ireland. No Irishman, no Englishman, could do that; and in this lies the special quality and value of his worls. We are not accustomed to this objective method of.treatment, and it is hardly to be expected that we shall altogether enjoy it. But Dr. Bonn did not write to please us, or even to teach us, but simply to give the fruit of his observations to the readers of the German scientific publication in which this essay first appeared.* He did not then contemplate its appearance in an English translation. But it seemed worth making known to English readers for two reasons : first, because it brings together in small compass and in systematic order a multitude of facts gleaned from very extensive studies in the central economic question of modern Ireland; secondly, because it contains much critical comment on

*Archiv für Sozialwissenschaft und Sozialpolitik, Verlag von J. C. B. Mohr in Tübingen, xix Band, I Heft, u. xx Band, 3 Heft. "Die irische Agrarfrage," von Dr. oec. publ. Moritz Julius Bonn. Thanks are due to the Editors of the "Archiv" for permission to publish this translation. 
these facts as they appear to a highly trained and competent foreign observer.

The root idea, as it appears to me, of Dr. Bonn's work is as follows:-After a careful diagnosis of the existing situation, he exposes in masterly fashion the absolute fatuity of the Gladstonian land legislation, regarded as a settlement of the Irish land question. The Land Purchase Acts are, of course, recognised by Dr. Bonn as a considerable advance, in point of statesmanship; still there are two serious drawbacks to them-they are irregular in their application, and thus often work extreme injustice, especially to the better class of tenant-farmers; and - a more serious and fundamental vicethey have placed the idea of property before the Irish tenant as something which he has to be bribed into acquiring, not as the goal and reward of self-denial and of strenuous industrial effort. It, therefore, behoves those who can look a little ahead of the difficulties and entanglements of the present day to consider how best to avert the danger that property gained in such a way may produce not a bracing but a slackening of industrial energy and ambition. Dr. Bonn finds the one sure hope of the nation in the strengthening and extension, in the widest 
and most varied way, of the co-operative movement. What the individual will never do of himself he will often do eagerly and successfully as a unit in an organization, where the aims to be sought by all are defined by a few exceptional minds, which, it is possible, may sweep the whole body along with them in the current of their energy and will. An organized body must move as a mass or fall to pieces. Hence the peculiar social and economic value of co-operation, particularly in countries where the traditions of industrial enterprise are not strongly established. The Wyndham Land Act, therefore, cannot in any real sense be regarded as a settlement of the Irish agrarian problem. But if it removes that problem, at least as regards a great part of the island, from the sphere of politics and places it in that of voluntary social effort, it will have accomplished a great task and opened the way to a new era.

Such is the conclusion which Dr. Bonn has drawn from his study of this country. It amply confirms the views which have been long entertained and put into practice by the pioneers of reform in Ireland. But the extension of their practical work is a matter of imminent concern to the country, for the forces of new life have 
not yet begun to gain upon the forces of decay. If the Irish question, as Dr. Bonn concisely puts it, is a "turnip question," then the latest reports, which have come to hand as I write, give little encouragement to those who would fain believe that the economic decline of Ireland has touched bottom. The nation's life is still ebbing, and the mind of the nation, as a whole, is not yet alive to the danger and to its source.

\section{T. W. ROLLESTON.}

\section{Glenealy,}

Co. IVICKLOW. 



\section{MODERN IRELAND AND HER AGRARIAN PROBLEM.}

\section{PART I.-THE IRELAND OF TO-DAY.}

\section{CHAPTER I.}

ENGLAND'S FAILURE IN IRELAND, (a) POLITICAL.

Seven hundred and thirty-six years have passed to-day ${ }^{1}$ since the commencement of England's colonising activity in Ireland. Whilst the English colonization policy has, on the whole, been successful in every quarter of the globe, every reader of the newspapers is aware that, even at the present day, Ireland is not content with its results. With the exception of the north-eastern portion of Ulster, Ireland has not yet reconciled itself to English rule. Ulster is essentially a colonial settlement. If we assume, as in a certain sense is justifiable, that the colonist population belongs to the Protestant religion and the native population to the Catholic, we find in Ulster a slight predominance of Protestantism and consequently of the colonist element, since there are only 442 Catholics to every $\mathrm{I}, 000$ inhabitants in that

${ }^{1}$ [The standpoint in time of this work may be taken as the year 1905 , for though a portion of it appeared at an earlier period, the statistics have, where necessary, been brought up to date in the notes. Transl.] 
province. Protestant Ulster must, on the whole, be considered separately from the Ireland of the Irish problem. With its dour, hard-headed, industrious population, which gravitates principally to Belfast, it is a land of modern industrial and social structure. To no one who has ever seen it, with the intensive economic life which appears both in its agriculture and its industry, will it seem an earthly paradise. One finds much more resemblance to such a paradise in the famine mountains of Connaught, where a race of lotus-eaters is slowly dying out because in those regions the lotus thrives but poorly. But Ulster is a modern land with modern problems which do not greatly differ from those of other WestEuropean countries.

With the exception of Ulster, Ireland is to-day still anti-English. Out of IO3 members whom it sends to London to the Imperial Parliament there are always over 80 Nationalists, who regard it as their mission to create difficulties for every English Government, who judge all English questions only from the standpoint of Irish interests, without regard to their intrinsic merits, and who attach themselves to English parties only when tangible advantages for Ireland are thereby to be obtained. They systematically sympathise with and applaud every foreign enemy of England, not excepting even the horde of fanatics who latelyoverran the Soudan and threatened Egypt; and they seek from time to time to render the English Parliament powerless and to discredit 
it in the eyes of the world, by evoking cleverly arranged scenes of tumult. All these things are not so serious as they sometimes appear; for there is a good tincture of theatrical display in such demonstrations. When the enemies with whom Ireland's representatives exult are finally conquered, it is probably by means of regiments whose ranks were recruited in the Green Isle. These violent scenes in Parliament are called for in order to furnish a proof to the irreconcilable elements of Irish Nationalism of the vitality of the Parliamentary section, and also to evole from time to time fresh contributions from the Irish in America. If a British Sovereign comes to Ireland, and treats with consideration the religious and national sentiments of the people, he may, in spite of the outcry of the irreconcilables, count upon a very gratifying reception; he will not, however, secure thereby a solution of the Irish question.

The political methods by which England usually governs such of its territories as are inhabited by a white population have only been partially applied in Ireland. Not only does Ireland not possess its own legislature, but the democratic local government which alone ensures the sympathy of the populace was only introduced by the Act of 1898 . At the same time the part played by the central Government in Ireland-it is seated in Dublin Castle, and is therefore called "The Castle"-is infinitely more important than is the case in 
Scotland or England. The cost for the administration of justice, for police, and for internal administration was found in 1895 to amount to:-

In England and Wales, with $30,000,000$ inhabitants
… $£ \mathrm{r}, 400,000$
In Scotland, with 4, 100,000 inhabitants $2 \mathrm{~T} 9,000$
In Ireland, with 4,600,000 inhabitants
$2,025,000^{1}$

The administration of Ireland lies to a large extent in the hands of the Royal Irish Constabulary, an excellently organized little army, subject to the central Government. The numbers of the Royal Irish Constabulary from I876 to I895 averaged about I2,000 men; the yearly expenses were $f I, 400,000 .^{2}$ The strength and organization of this constabulary and also the costliness of the Irish Government prove that to English administration in Ireland, the feeling of perfect security is unknown. It rules through the police, and in point of fact only makes itself noticeable in other respects by travelling inspectors from the different departments. A number of institutions of traditionally English type pursue their functions not very brilliantly. 'The judge, whose impartiality in England is raised above every doubt, is in Ireland nominated, as a rule, from the political adherents of the Government, and seldom

${ }^{3}$ Financial Relations Commission I., p. 4I3. The police of course are an Imperial charge in Ireland, not in Great Britain.

${ }^{2}$ Financial Relations Commission II., p. 237. 
enjoys-whether rightly or wrongly, I will not decide-the reputation of strict impartiality. As a set-off to this, the juries, who are chosen from the people, almost systematically delight in acquitting political or ostensibly political prisoners whose guilt is unquestionable, whence it comes the Government has often been obliged to influence the composition of the juries. A number of crimes, which, for any protracted period, are as good as unknown in the civilized states of western Europe, occur every year in Ireland. These are agrarian crimes ranging from threatening letters and intimidation, from cattle-maiming and arson, to boycotting and assassinations of downright bestial savagery. Of such crimes there were, from I844 to I890, no fewer than 35,534 . In 1894 there were 276 ; in $1893,26 \mathrm{I}$; and in $1902,253 .{ }^{1}$ The danger of an organized Irish revolution which is to take place at a moment when England is involved in political complications may, however, be estimated as very slight. The Transvaal war seemed at last to have furnished the opportunity so long and so ardently desired by Irish patriots; but on that occasion the contrast between word and deed among the intransigeant party in Ireland and America was conspicuously great. On the other hand, isolated outbreaks are not impossible, though the last few years have passed quietly. In every Irish town there is a certain sediment of irreconcilable Nationalist revolution-

1 Thom's Official Directory. 
aries, to whom dynamite may seem applicable to the service of the idea of Nationality. A certain inclination to acts of lavlessness because they are acts of lawlessness dwells in the Irish mind and plainly shows the political failure which England has achieved in Ireland. It is illustrated by nothing better than by the fact that England does not venture to extend the English Volunteer system to Ireland. I should have to write a history of English colonization in Ireland if I wished to raise the question here as to why it has failed. The fact of the failure is clear from other considerations as well. 


\section{CHAPTER II.}

ENGLAND'S FAILURE IN IRELAND, (b) ECONOMIC.

DURING the colonization period it was one of England's principal objects to win Ireland over to Protestantism. A glance at statistics shows how unsuccessful this attempt was. The population of Ireland to-day amounts to $4,458,775$. Of these I, I 50, I 4 belong to the various non-Romanist religions, such as the Episcopalian Protestant Church, the Presbyterians, the Methodists, \&c. 3,308,66I are Roman Catholics, that is a proportion of $74^{\circ}$. I per cent. Since the middle of the last century the proportion between Roman Catholics and all others has altered somewhat in favour of the latter. The Roman Catholics numbered

\begin{tabular}{|c|c|c|c|}
\hline 8 & & & $77^{.6} 9$ per cent. \\
\hline 80 & .. & .. & $76 \cdot 54$ \\
\hline 01 & $\ldots$ & $\ldots$ & $74^{\circ} 21$ \\
\hline
\end{tabular}

of the population. This slow reduction has not arisen from any increase of the other religions; it has rather resulted from the still larger reduction of Roman Catholics, not, however, by conversions but by emigration. The hope that a considerable proportion of the Irish population 
would be won over to Protestantism through colonization has been totally frustrated. We may say, without much exaggeration, that the non-Romanists, with ferv exceptions, are descended from colonists.

The English Government has been somewhat more successful in the abolition of Irish customs and usages, and above all in the extermination of the Irish language. The number of persons who understood Irish were :-

\begin{tabular}{|c|c|c|c|}
\hline Year. & Individuals. & $\begin{array}{l}\text { Percentage } \\
\text { of } \\
\text { Population. }\end{array}$ & $\begin{array}{l}\text { Persuns } \\
\text { understanding } \\
\text { only Irish. }\end{array}$ \\
\hline I 88 I & 949,932 & I $8 \cdot 2$ & 64,167 \\
\hline IS9I & 680,245 & 145 & 38,192 \\
\hline I 901 & 641,142 & $14^{\circ} 4$ & 20,953 \\
\hline
\end{tabular}

Here we have therefore a considerable retrogression in the Irish language. Within the past few years a movement, under the direction of the "Gaelic League," has been set on foot, with the object of resuscitating the ancient Celtic habits and customs and above all the language and literature. The English Government has offered no resistance to this, and has even subsidized the teaching of Gaelic in the schools. It has probably seen that the mere external assimilation of a population of foreign stock has no great value, and that, so long as the Irishman does not feel that he coalesces politically with the British Empire, the use of 
the English language offers no guarantee for him. Imperialism, as it is now understood by the best minds in England, is in keeping with this procedure. It does not mean a Chauvinistic accentuation of English feeling; it rather sets before it the goal of furthering and developing in their own particular fashion, a number of races politically linked together and forming a great Empire, who, while they strive for one public end, shall supplement and complete each other.

But England never desired the mere external Anglicization of Ireland; it wanted to create conditions there which should render possible a healthy economic development. As far as concerns the general education which England bestowed upon Ireland, the results are not brilliant, though substantial advances may be noted. If we inquire what percentage of the population of Ireland over five years of age can neither read nor write, we find this to be in the following years:

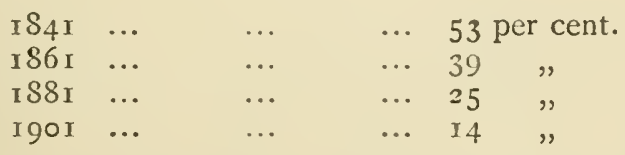

In particular parts of the country and in individual groups of the population things in IgOI were still worse. In Connaught 2 I per cent. were illiterate. The entire Roman Catholic population of Ireland showed a percentage of 
I6.4, and the Roman Catholic population of county Donegal a percentage of actually $3 \mathrm{I} .{ }^{1}$

The picture of Irish development grows still darker when we look at the population statistics. In I84I the census fixed the population of Ireland at $8,175,124$ souls. The census of Igo I shows a population of $4,458,775$; a diminution in the population of $3,716,349$ has therefore occurred. I will not here go into the history of Irish emigration, nor into its causes. Let it be sufficient to mention that from I85I to IgOI $3,735,725$ individuals emigrated. In spite of such a decline in population, in spite of the fact that Ireland with its 97 heads per square mile is to-day anything but a thickly populated land, emigration still continues. It amounted to-

$$
\begin{array}{llll}
\text { I } 900 & \ldots & \ldots & 45,228 \text { persons. } \\
\text { I } 901 & \ldots & \ldots & 39,6 \text { I } 3 \quad, \quad
\end{array}
$$

56.4 per cent. of these emigrants were between the ages of 15 and $25 ; 24$. I per cent. between the ages of 25 and 35 . Of 16,927 persons

"As the Census from which all these figures are taken very rightly remarks, no conclusions as to the quality of the population belonging to the different confessions can be deduced from them. The simple fact that the Roman Catholics form the majority of the country, and also the greater proportion of the poor population, explains these figures completely.

$\begin{array}{rlllc}2[1902 & \ldots & \ldots & 40,190 & \text { persons. } \\ 1903 & \ldots & \ldots & 39,789 & , \\ 1904 & \ldots & \ldots & 36,902 & , "\end{array}$


between the ages of 20 and 25 , only 44 men and 201 women were married. It is the effcient and enterprising youth of the country who are emigrating, in order to obtain opportunities for bettering themselves in the greater Ireland which they find in the United States. The majority go out as unskilled labourers. Of I8,343 men, 658 were farmers, and 13,359 labourers; of 21,527 women, I5,638 are described as servants. ${ }^{1}$

Nor does the composition of the population remaining in the old country show any feature of economic youth and strength. To every I 00,000 the number of those under 20 years of age is 40,952; of those from 20 to 55 years of age, 44,789 , and of those over 55 years of age, I4,259. This division of ages is not unlike that of the French population: it shows a small proportion of the youthful classes ( 303 under I 5 years per I, ooo in Ireland, 262 in France, but 35 I in Germany), and a large proportion of persons over 60 years of age (Ireland I05 per I,000, France I25, but Germany only 80).

If we look at the births and deaths we find the births figure set down at $23^{\circ} \mathrm{O}$ per I, ooo of the population, as against 18.2 for the deaths. During the Census year (IgOI) there occurred I00,976 births and 79,II9 deaths. But this apparently not unfavourable circumstance

${ }^{1}$ Emigration Statistics, I90I. Irish Enigration is discussed in detail by Karl Rathgen, "Englische Auswanderung and Auswanderungspolitik." 
loses in importance when we look at the number of marriages. In IgoI there were I, 049,4I3 women of child-bearing age (I5-45) in Ireland, of whom only 34I,254 were married, altogether 32.5 per cent. The number of married women is continuously diminishing in proportion to the number of marriageable women. ${ }^{1}$ It is only in the backward districts of Connaught that marriage frequency is greater. In every Ioo women of over 20 years of age in Mayo, there are only 33.3 unmarried, whilst in County Dublin there are about $52 \cdot 2$-that is, more than half. As illegitimate births, especially in the Catholic portions of Ireland, play no part, we perceive from these figures the slow natural increase of the population.

" Estimated by the number of married women of the child-bearing age, the natural increase of population in Ireland is at present very small," says the Census. The picture of Ireland which we used to conjure up, as a land of early marriages, resulting in numberless children, has long been incorrect. We may say without much exaggeration that a large part of the population which is marriageable, and which desires to marry, leaves Ireland every year to establish a home beyond the ocean. Far truer than the notion of a race multiplying like rabbits is the saying of George Moore: "Nothing thrives in Ireland, but the celibate."

${ }^{1}$ Census, 22. 


\section{CHAPTER IIl.}

SOCIAL CONDITIONS OF THE PEOPLE.

IRELAND is a poor country. Anyone who has wandered through the endless mountain wastes of Connaught, who has seen the dirty slums of an Irish town, inhabited by a modern proletariat without modern industrial development, will scarcely need to look out figures for his impressions. At the same time statistics confirm his conceptions. According to a calculation of Sir Robert Giffen, which was laid before the Commission on Financial Relations, for the work of which it was, in a certain sense, taken as a basis, the income of Ireland may be calculated at from 63 to 76 million pounds. ${ }^{1}$ This estimate, with a population of $4 \frac{1}{2}$ millions, would give an average income of from $\ell^{15}$ to $\ell^{16}$. Small as this average income appears (and it must be considerably lower in the west), it is the result of a growth, though certainly a slow one. The

1 Final Report of the Royal Commission on the Financial Relations between Great Britain and Ireland, p. 1 74, et seq. 
assessments for income tax (" net assessments") amounted to :-

$\begin{array}{rlllr}\text { I } 854 & \ldots & \ldots & \ldots & t, 21,330,000 \\ \mathrm{I} 864 & \ldots & \ldots & \ldots & 23,000,000 \\ \mathrm{I} 874 & \ldots & \ldots & \ldots & 27,080,000 \\ \mathrm{I} 884 & \ldots & \ldots & \ldots & 27,062,000 \\ \mathrm{I} 894 & \ldots & \ldots & \ldots & 27,351,000^{1}\end{array}$

The income tax is a somewhat deceptive standard, as it only falls upon incomes of more than $f 160$, and the majority of incomes in Ireland are, undoubtedly, below this figure. But other statistics, such as the increase in cattle, lodgments in banks and savings banks, and perhaps railway traffic, show a certain progress. The lodgments in savings banks amounted to:-

$$
\begin{array}{llllr}
\mathbf{I} 870 & \ldots & \ldots & \ldots & £ 2,700,000 \\
\mathrm{I} 880 & \ldots & \ldots & \ldots & 3,700,000 \\
\mathrm{I} 890 & \ldots & \ldots & \ldots & 5,700,000 \\
\mathrm{I} 894 & \ldots & \ldots & \ldots & 6,970,000^{2}
\end{array}
$$

From this we can scarcely derive any farreaching conclusions, except that the poverty of Ireland is somewhat less to-day than it was a few decades ago. A certain progressive activity is showing itself in certain quarters. For

${ }^{1}$ Financial Relations Report, p. 58. [The subsequent returns, however, show a marked decrease. Transl.]

${ }^{2}$ Financial Relations Report, p. 207. [In 1905 the returns show a balance of $\mathcal{E}_{12,496,000}$ in Post Office Savings Banks and Trustees Savings Banks. Transl.] 
example, the capital in limited liability companies amounted to :-

$\begin{array}{llllc}\text { I } 880 & \ldots & \ldots & \ldots & £ \mathrm{I} \mathrm{I}, 500,000 \\ \mathrm{I} 890 & \ldots & \ldots & \ldots & \mathrm{I} 9,000,000 \\ \text { I } 894-95 & \ldots & \ldots & 25,480,000^{1}\end{array}$

Such figures show the direction in which Irish political economy is moving; they tell us little of its present condition.

A detailed account of housing conditions is given in the Irish Census. The houses are divided into four classes. The lowest (fourth) class are mud cabins with one window and one room; the third class consists of cottages having from one to four rooms and the same number of windows; the second class are decent farmhouses with from 4 to 9 rooms and windows; the highest class are really good houses. If we accept this classification, we obtain the following figures. There were in the-

\begin{tabular}{|c|c|c|c|}
\hline & $\begin{array}{l}\text { Number of } \\
\text { Houses } \\
\text { in Towns. }\end{array}$ & $\begin{array}{l}\text { Number of } \\
\text { Houses } \\
\text { in Country. }\end{array}$ & $\begin{array}{l}\text { Total } \\
\text { Number of } \\
\text { Houses. }\end{array}$ \\
\hline $\begin{array}{l}4^{\text {th }} \text { Class } \\
3^{\text {rd }},\end{array}$ & $\begin{array}{r}527 \\
22,268\end{array}$ & $\begin{array}{r}9,346 \\
229,33^{8}\end{array}$ & $\begin{array}{r}9,873 \\
251,606\end{array}$ \\
\hline 2nd & I 7 1, 792 & 349,662 & $5^{2} \mathrm{I}, 454$ \\
\hline I St & 36,525 & $3^{8,700}$ & 75,225 \\
\hline
\end{tabular}

If we take into consideration the fact that in many cases more than one family inhabits the

${ }^{1}$ Financial Relations Report, p. 207. [For 1904-5 the figure is $£ 42,409,899$. Transl.] 
same house, and if we classify not the houses but the dwellings, we get the following picture :-

\begin{tabular}{|c|c|c|}
\hline $\begin{array}{l}\text { In dwellings } \\
\text { of the }\end{array}$ & $\begin{array}{c}\text { Rural } \\
\text { Districts. }\end{array}$ & $\begin{array}{l}\text { Urban } \\
\text { Districts. }\end{array}$ \\
\hline $4^{\text {th }}$ Class & I I ,869 & 29,354 \\
\hline $3^{\text {rd }}$, & 234,380 & 53,6 I 8 \\
\hline 2nd $"$, & $34^{8}, 7^{6} 3$ & 164,322 \\
\hline Ist & 37,733 & 30,217 \\
\hline
\end{tabular}

The Irish mud cabin with its hump-backed straw roof which in place of a chimney has a hole, whose windows, if indeed any there are, cannot be opened, whose floor is the bare ground, whose furniture is a couple of planks which serve as a bed and a couple of other planks which claim the title of cupboard, is the most primitive dwelling-place that can be imagined. It has frequently no proper fireplace; against one of the walls and on the bare ground the turf is set alight. The only ventilation effected is through the door or the hole in the thatch. A couple of little stools and a dresser upon which stand broken cups complete the furniture. Frequently cow and calf, pig and hens, share the dwelling with the owners. Of such houses there are Io,000 in Ireland. But the houses also of the third class, often built of loose stones, sub-divided by partitions into several rooms and generally having two doors which can be closed according to the direction of the wind, exhibit, for the greater part, such a low degree of comfort as is 
probably not to be found among any other WestEuropean people. The bare earthen floor will probably be found in most of them. The Irish standard of life is extraordinarily low, and therefore all these outward signs of poverty are in a certain sense misleading. The Irishman is frequently not so poor as one might conclude from his manner of living. The power of existing under miserable conditions of life, of eking out an existence and of propagating his species on soil where a Central European goat would die of hunger, has doubtless preserved the Irish people during the long period of scorn and oppression. But it is this also which nowadays makes economic progress and development so infinitely difficult. A people which is contented with a little milk and potatoes, with tobacco, a little whiskey and strong but bad tea, does not produce the elements which the modern industrial world requires.

About one-third of the Irish population, altogether I,384,929, lives in the towns; of these 892,463 live in nine boroughs, that is towns which elect members of Parliament. Whilst the total population since I8g I has decreased by some thousands, the population of the towns has grown by 139,670 . If we examine the town population with regard to religious conditions, we find that there are in the boroughs 59.5 per cent. of Roman Catholics, and in the remaining towns 62.6 per cent. Thus the proportion of Catholics to Protestants is less favourable in the 
towns than in the open country, for the average for all Ireland is 74 per cent. In a certain sense, therefore, the aim of the old English policy, to keep the towns Protestant, has been attained. Outside Dublin and Belfast, only some half-dozen places really give one the impression of towns. The rest consist, except in Ulster, of villagelike agglomerations of houses, market centres, Government centres and-not to forget the most important point-drinking centres, of the agrarian districts. Many of these small Irish towns are the most depressing sight that one could see in Western Europe. The misery of the open country is at least softened by the impression of distance. Here the dirty cabins, planted close against each other, line neglected streets to which a few houses of several stories seek in vain to impart an urban character. There is scarcely any urban society with cultivated interests. The clergy of the different denominations, a couple of officials, a land-agent or two, the manager of the local branch bank, a doctor, a lawyer; that is all the culture-bringing element which is to be found; there is perhaps a convent in the neighbourhood, and one or two grammar schools not calculated to advance the mind in any excessive degree. Justice however demands the admission that the poor quarters of a large town with their windowless, neglected houses, on the front steps of which the whole body of inhabitants are accustomed to sit, not exactly in silence, are at least the match of the smaller 
towns in decay and revolting dirt. The rest of the population live partly in village-like settlements only distinguished from the towns by the absence of self-government, partly in scattered hamlets and in lonely cabins on the bogs or the mountain slopes. The thinner the population becomes, the lonelier will Ireland be; the emptier and stiller the life of this joyous people. 


\section{CHAPTER IV.}

OCCUPATIONS OF THE PEOPLE.

THE occupation statistics divide the Irish population into six classes. The first class comprises the liberal professions, \&c., and contains I3I,035 individuals. To it belong doctors, lawyers, officials, \&c. The second class contains household employees, servants, \&c.; it comprises 2 I9,4I 8 persons. The third class contains the commercial callings, with 97,889 individuals; agriculture forms the fourth, with 876,062 individuals, and industry the fifth class with 639,4I3. Finally, the sixth class, containing $2,494,95^{8}$ persons, is composed of those following occupations not more fully specified, and chiefly the great masses of people who have no calling whatever. From the Irish Census we cannot learn much that is valuable from the point of view of political economy; it supplies a collection of individual economic facts rather than an entire and systematically thoughtout view of Irish economic life. At the first glance, the commercial and. industrial classes seem to have almostas much weight as the farming class. But to this latter must also be reckoned some II 5,540 more persons generally described 
as "labourers." Moreover, the Irish industries in question are mostly minor industries with small capital, or such as supply local needs-for instance, building firms, clothing factories, \&c. The most important industry is perhaps the traffic business, which employs altogether 58,566 persons.

${ }^{1}$ In the first rank are the railways. Ireland is a land of private lines; there are about thirty private companies, the network of which is about 3,2I4 English miles in length. Their working capital amounted in 1902 to about forty millions. The excess of the receipts over the expenses was I. 58 millions, producing an interest therefore of exactly 4 per cent. The Irish railways are in the main passenger lines. Of the gross receipts two millions were brought in by the passenger traffic, and the rest of the receipts is divided as follows :-

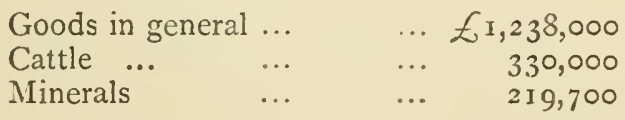

Whilst in England an income of fifty-seven millions from goods transport is balanced by an income of 33.4 millions from passenger traffic, the relation between the two in Ireland is as

"For the following, see "Ireland, Agricultural and Industrial," edited by IV. P. Coyne, pp. 73 et seq., and Railway Statistics; the Census Report has been also used here, as in other places. 
28 THE IRISH AGRARIAN PROBLEM.

I,787 to 2,098 millions. ${ }^{1} \quad$ Transport rates in Ireland are high, much higher than in England. Whilst in I890 transport per ton was $22^{\circ} 75$ per cent. dearer than in England, it had risen in Igoo to $37^{\circ}$ I4 per cent.

Land transport by road, \&c., occupies I8,985 persons, and shipping in its different branches I 5,252 .

The greatest Irish industry is the textile industry, in particular the linen industry of Ulster which is, in point of fact, one of worldrenown. In IgOI there existed 5 I spinning factories or spinning companies with 835 , IOO spindles. The number of mechanical looms was $3 I, 484$. The export of all kinds of linen from the United Kingdom was estimated at five million pounds for the year IgoI (Sir R. Lloyd Patterson, at the Cork Industrial Conference, pp. 38, 47, 48). The number of employees was $77,46_{5}$, of whom 809 were engaged in the cotton indurstry. In addition to these, some 30,000 were employed in bleaching establishments. The woollen industry, on the other hand, has essentially the character of a local industry. A great deal of spinning is done in the cabins; but there are about II4 rather small weaving concerns employing 3,323 workers. ${ }^{2} \quad$ Altogether the woollen industry gives employment to 5,348

${ }^{1}$ In the English figures no receipts whatever from luggage or letter transport are included.

2 "Ireland, Agric. and Ind.," p. 40I. 
persons. The total number of those engaged in the textile industry is 109,588 . Apart from this, the clothing industry, including tailors, bootmakers, and hatters, gives the largest amount of work to industrial employees. With the exception of some boot factories, the underlinen industry about Londonderry, which employs about 80,000 hands, ${ }^{1}$ is the only industry of this group which comprises big factories. It is however still organised to a large extent as a domestic industry.

Mining is unimportant. The coal mines send out little more than IOO,000 tons. The value of all mine products amounts to about $£ 250,000$; the number of persons engaged in mining is about 6,386. Fisheries employ I I, ooo individuals.

In addition to these, three Irish industries of world-wide reputation must be mentioned; beerbrewing, whiskey-distilling, and the great shipbuilding yards of Belfast. The 39 beer breweries in Ireland produced in Igor over three million barrels, of which about two million were consumed at home. ${ }^{2}$ All other firms are overshadowed by Guinness's Brewery, whose annual profit of late years has been about $f 800,000$. The 30 whiskey distilleries produced in I9O I $\mathrm{I}^{.} \cdot 2$ million gallons, of which about $4 \frac{1}{2}$ millions were consumed at home. ${ }^{3}$ Besides these large

\footnotetext{
1 " Ireland, Agric. and Ind.," p. 4 8.

2 "Ireland, Agric. and Ind.," pp. 459 et seq.

3 "Ireland, Agric. and Ind.," p. 499.
} 
concerns, illegal distillation is secretly carried on in many peasants' cottages in the West, where the so-called "poteen" is manufactured, which is especially dear to the Irish whiskey drinker, by reason of the difficulty of obtaining it and the danger and illegality of its production. No fewer than I, 404 of the stills used in this connection were seized in I9O2 by the police.

The alcohol industry, though only employing 5,400 persons, affords a great number of dealers and publicans lucrative opportunities for gain. It is estimated that there are in Ireland 30,572 general shopkeepers whose economic success would often be doubtful without a publican's license. In IgO2 25,206 licenses were issued. ${ }^{1}$ The battle for licenses is a moment in Irish life which is much weightier and more important than the battles in the political arena which fill the columns of the newspapers. The power of the publican in the political life of Ireland is making itself felt more and more. In this impoverished country they are the capitalist class, and as such exert a powerful influence.

The last great industry-and it has a worldwide reputation-are the great shipbuilding yards in Belfast, especially those of Harland \& Wolff, which employ about 9,000 hands. In Igoo their production amounted to 93,3 I6 tons gross. The importance of this industry for Belfast lies, apart from every other considera-

1 Thom's Official Directory. 
tion, in the fact that it supplements the textile industry; the female population works in the spinning factories, the men in the yards.

When we consider all these figures we can scarcely say that Ireland gives the impression of an industrial country; in the main it is an agrarian country, and, so far as we can see, it will remain an agrarian country with the exception of the east coast. 


\section{CHAPTER V.}

TENDENCIES OF IRISH AGRICULTURE.

THE area of Ireland amounts to $20,350,000$ acres. These are utilized as follows :-

Acres.

Corn, roots, potatoes, etc. $\quad \ldots \quad \ldots \quad$ 2,373,000

Meadows, and temporary meadows, hay from permanent pasture $\quad \ldots \quad 2,260,000$

Fallow and fruit $\quad \ldots \quad \quad \ldots \quad \quad \ldots \quad r, 500$

IVoods, \&c. $\quad \ldots . \quad \ldots \quad \ldots \quad \ldots \quad 303,000$

Bog, waste, barren mountain, water, \&c. 4, SI 7,600

These figures already show us that Ireland is a pasture country. The area devoted to meadow is $2,260,160$ acres ; to these are added Io, 586,639 acres of permanent pasture, making a total of $12,846,799$ acres, or more than two-thirds of all the arable land. Ireland is accordingly a cattle-rearing country. The cattle are estimated as follows :-

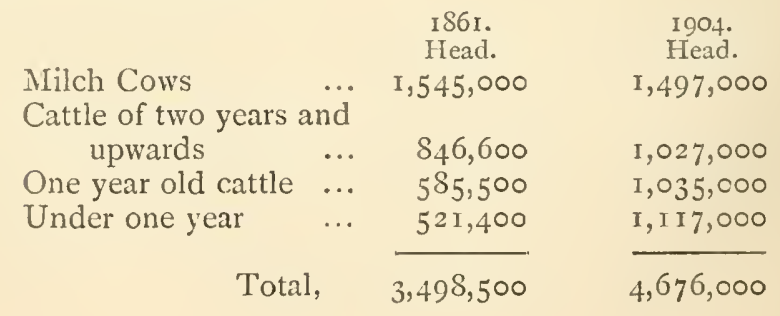


If we compare these figures, we find a decrease in milch cows of nearly 3 per cent.; an increase in cattle under a year old of II4 per cent. ; an increase in the total stock of cattle, excepting the cows, of 62.7 per cent., and including cows of $33^{\circ} 6$. These figures prove that Ireland is developing more and more from a milk-producing country into a meat-producing country.' Other live stock amount to-

Sheep (which are diminishing in number) $4,200,000$

$\begin{array}{llllrr}\text { Pigs } & \ldots & \ldots & \ldots & \ldots & \mathrm{r}, 350,000 \\ \text { Horses } & \ldots & \ldots & \ldots & \ldots & 565,000 \\ \text { Asses } & \ldots & \ldots & \ldots & \ldots & 239,000 \\ \text { Goats } & \ldots & \ldots & \ldots & \ldots & 5 \mathrm{I} 2,000 \\ \text { Poultry } & \ldots & \ldots & \ldots & \text { about } & \mathrm{I} 8,000,000\end{array}$

The exports of live stock to England for an average of three years (I900-I9O2) amounted to-

$\begin{array}{llllll}\text { Cattle } & \ldots & \ldots & \ldots & \ldots & \begin{array}{c}\text { Head. } \\ 782,466\end{array}\end{array}$

or 13.8 per cent. of the total live-stock; excluding the cows, some 25 per cent.

Sheep … 920,000, or 19.3 per cent.;

Pigs ... 650,000 , or 48.9 per cent. of the total.

The value of these live stock exports amounted to-

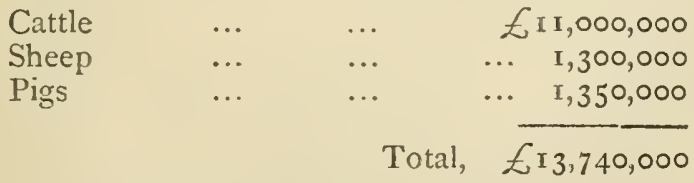

${ }^{1}$ Agricultural Statistics, $1904 . \quad{ }^{2}$ Thon, 1903, p. 639. 
The total value of live stock is estimated at between 42 millions and 7 I millions; that of the horses at I $2 \frac{1}{2}$ millions. ${ }^{1}$

Irish agriculture shows us another picture. There are planted with

Cereals and flax Root Crops Meadow ...

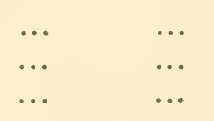

altogether, 4,634, I 25 acres. ${ }^{2}$

The value of the harvest amounts on the average to 33 millions. ${ }^{3}$ Of this, there come to :-

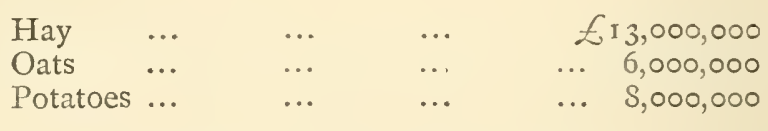

These three most important harvests yield 27 millions sterling (according to the Agricultural Statistics of I902). ${ }^{4}$ These figures also show that Ireland is a pastoral land with little agricul-

Thom, 1903, pp. 738 and 746. [The estimate of 42 millions is on the basis of the prices of $184 \mathrm{I}-7 \mathrm{r}$ millions is the more correct figure. Transl.]

${ }^{2}$ [For 1905 the returns are-

$\begin{array}{lllll}\text { Cereals and flax } & \ldots & \ldots & \ldots & 1,317,348\end{array}$

$\begin{array}{lllll}\text { Root crops } & \ldots & \ldots & \ldots & 1,317,348 \\ & & & \ldots & \end{array}$

$\begin{array}{lllll}\text { Meadow } \ldots & \ldots & \ldots & \ldots & 2,294,506\end{array}$

${ }_{4}^{3}[30$ millions in $1904 . \quad$ Transl. $]$. 
ture, and with 'extensive' technical methods.' Altogether 876,000 persons were engaged in agriculture, of whom about 140,000 (men and women) are designated as labourers and cottagers; 85,000 as indoor servants, and in addition to these we must also add to the agricultural population some of the I8I,000 individuals generally described as labourers.

Ireland is a land of permanent pasture. Even the fact that out of I5 million acres of arable land only 350,000 acres are allotted to turnips, shows how little an intensive system of crop rotation is followed in Ireland. As a denser population is impossible without agriculture, and intensive agriculture can scarcely be pursued without turnips, the Irish question is ultimately a 'turnip question.' Two-thirds of the country

1 Thanks to the extraordinary fruitfulness of the soil taken into cultivation, the yields from the various crops are substantially greater than in England. The average yield in the years $1893-1902$ amounted to :-

\section{England.}

Wheat per acre $\quad \ldots \quad 30^{\circ} 5^{2}$ bhls. Oats Barley Hay from permanent pasture But Potatoes

$\begin{array}{lll}\ldots & 40.36, \\ \ldots & 32.62,\end{array}$
$32 \cdot 62$, $22 \cdot 62$ cwt. 5.96 tons.
Ireland. 32.2 I bhls. $44 \% 47$, $39^{\circ} 23$ 46.5 I cwt. $3 \cdot 87$ tons.

The potato is the poor man's crop, and is therefore wrung from poor soils (Agricultural Statistics, 1903). [Considerable doubt exists as to the accuracy of the estimated yield of crops in Ireland, and in the returns for 1905 (cd. 2854) the question is stated to be under investigation. Transl.] 


\section{6 THE IRISH AGRARIAN PROBLEM.}

is never touched by plough or spade. Many parts of the country, especially in the counties of Kildare, Meath and Dublin, are nothing but grassy deserts covered with a dense growth of shimmering, almost blue-green, grass and subdivided into fields by hedges and ditches. There is scarcely a human being to be seen, for the cattle graze without a herdsman in the hedgedin fields, in the centre of which a solitary post or stone against which the animals can rub themselves is almost the only mark of human effort. Hundreds and thousands of ruined cot. tages are scattered about, dwellings in which human beings formerly dwelt. The number of inhabited houses fell, since $\mathrm{I}_{85} \mathrm{I}$ from I, I46,223 to 858,158 in Igor, a diminution of 188,065 houses. It is these wide "grazing ranches" which have made Ireland into a land of a great silence.

Both climate and soil favour pasture farming. The soils have, for example, been classified into

I. Fattening land.

2. Lowland pasture for dairy farming.

3. Lowland pasture, second quality.

4. Mountain pasture.

5. Bogs and waste lands. ${ }^{1}$

Coyne, "Ireland, Agric. and Ind.," pp. 29 et seq. Many statements in this essay are extracted from this excellent book, the author of which was till a short time ago head of the Statistical Branch of the Irish Department of Agriculture. An early death has snatched him from a valuable activity. Under 
With the exception of the coarsest soils in Ulster, the land, as soon as it is withdrawn from cultivation, covers itself with grass. The climate, with its regular moisture and slight cold in winter, favours grass farming and is not the most beneficial to tillage farming. Besides these physical reasons a host of other causes have co-operated to make Ireland a pastoral land. It is asserted that the abolition of the Corn Tax (1846) changed Ireland from an agricultural to a pastoral country. It is not my intention to discuss this question here, but it can be said with tolerable precision that no corn duties of fairly bearable dimensions would have been able to stay the great fall in the price of corn during the eighties. Up to that time it was not so much the fall in corn prices as the rise in meat prices which had caused the prevalence of cattle breeding in Ireland. Moreover, the Irish have always been a cattle rearing people, understanding little of agriculture and turning their attention exclusively to cattle breeding. The dense popu-

his supervision the statistical publications of the Department of Agriculture became a scientifically thought-out and practically useful source of information. Coyne was one of the few Irishmen who have brought a scientific training to the treatment of practical questions. The statistics which have issued from his department are among the few which try to answer questions in a scientific manner, and do not merely contain a collection of figures which may just as well serve to mislead as to illuminate public opinion. Very many difficult points in my Irish studies would never have been solvable without his help and advice. 
lation in the first half of the Igth century drove them to tillage, which was facilitated by high corn prices, but their agricultural methods were so primitive that they were in many ways detrimental to the fruitfulness of the soil. On small holdings the burning method mostly prevailed, and was carried on in an exaggerated and improper manner, impoverishing the ground for years to come. Even at the present day we see in the poorer meadows traces of former tillage in the remnants of ridges about a yard broad and known by the name of "lazy beds;" the poor growth of grass which here springs up shows how fertility has been destroyed.

Ireland is not only a land of cattle-breeding; it is a land of 'extensive' farming. Out of I2 million acres standing under grass, only from 2 million will the hay be cut. The planting of fodder crops, clover, roots, \&c., is very scanty. The cattle are generally both summer and winter in the open, although they often lose weight during the winter from the cold. Young cattle which in autumn are worth about $f 6$ or $£ 7$ a head are sometimes only worth from 20 to 30 shillings more in the following spring. ${ }^{2}$ The cows alone are stabled. In the west they are often to be found in the cottages of their owners. "The cow keeps the house warm " is an old Irish saying. Irish grass farming mainly consists in this, that

1 "Ireland, Agric. and Ind.", pp. 29 et seq.

${ }^{2}$ Journal of the Department of Agriculture, September, I903, p. I6. 
Heaven causes the sun to shine and the rain to fall, and that Man sends the cattle to the pasture and gives himself no further trouble about them. Even soils which would yield four times the profit with fodder crops are simply left under grass.

The following varieties of farming may be distinguished :

I. Dairying. The principal product sold, after the local sale of milk, is butter. Dairying is principally carried on in the pasture counties of Munster, namely in Cork, Limerick and Tipperary, but also in Ulster. Butter-making is nowadays carried on to a large extent in steam factories, the number of which is 609 and the production 479,000 civt. Amongst them there were in Igoo 236 co-operative dairies, with 26,477 members. These produced I $3 \frac{1}{2}$ million lb. of butter to the value of $£ 703,826$ sterling. ${ }^{1}$ The dairy system has prospered greatly through the co-operative movement. As, however, stall-feeding, and the growing of fodder requisite thereto, are only carried on to a slight extent, the winter production of butter, when the prices are highest, is not nearly as large as should be possible.

The farms which devote themselves to meatproduction may be divided into three classes:

1 "Ireland, Agric. and Ind.," pp. 220 et seq. [In 1904, according to the Report of the I.A. O. Soc. for that year, there were 328 co-operative creameries, producing over 20 million lb. of butter. Transl.] 
2. Farms which rear calves and either sell them soon or feed them until they can be sent out as young cattle. These farms sometimes produce not inconsiderable quantities of butter as well; they are to a large extent western farms, the small owners of which follow this occupation.

3. Farmers of this class buy young cattle and allow them to graze until they are nearly fit for market. These are called store cattle. These also are raised largely in the western counties. A large number of beasts so fattened are sent to England and Scotland to be finished for the market by rational feeding within a short time. In Igor 344,954 head of store cattle were exported. ${ }^{1}$

4. The next class is that of the rearers of fat cattle, who are settled in the rich grass counties of Meath, Dublin and Kildare, and who buy store cattle and within a comparatively short time finish them for market on their great 'ranches,' and send them to Dublin and to the English markets as fat cattle. In Igor 26I,6go head of fat cattle were exported. ${ }^{2}$

There is an intimate economic connection between these three forms of cattle-breeding. If the wide cattle ranches of Meath were ploughed

${ }^{1}$ Journal, Dept. of Agric., September, I903, p. I 7. "Ireland, Agric. and Ind.," p. 322. [On March S, I 906, Mr. Lloyd George stated in the House of Commons that the figure for the past five years was, on an average, 476,000 a year. Transl.]

2 "Ireland," etc., p. 322. [The figure for the year ending Sept. 30 , I 905 , is 229,967 . Transl.] 
up and given over to agriculture, an economic crisis would probably result in the West, for breeders of young cattle and unfinished cattle would necessarily lose their market. Cattle rearing is in a certain sense the national industry of Ireland. It is, with the exception of calf rearing, essentially a business of speculation. A man buys a beast cheap, lets it graze for a certain time, and sells it off at a higher price in as short a time as possible. It is not only the professional cattle breeder and the professional farmer who follow this business; in Meath servants often invest their wages in cattle, which their employer allows to graze in his pastures for a small payment; they thus make a little extra profit from this cattle speculation. The good meadows of the West are often set for I I months to the village shopkeeper, the solicitor, or the doctor-even the clergyman himself does not scorn sometimes to increase his scanty income by this means. A good proportion of these transactions are carried on by credit. It is more than likely that the majority of deposits lodged in Irish banks, in so far as they are not sent to England or employed by parties who have interests in the town, are used for speculation in cattle. When the Irish people are spoken of as a race of agriculturalists, what is really meant is cattle-dealers. The mere fact that to 545,202 occupiers of farms there are 6I 5,933 cattle-owners, points to this conclusion. ${ }^{1}$

${ }^{1}$ Agricultural Statistics, 1904, pp. 28, 95. 
5. The fifth type are the agricultural farms which occur principally in King's County, Queen's County, Wexford, Carlow, and are specially frequent in Ulster, with the exception of the Counties of Fermanagh and Cavan. ${ }^{1}$ Ulster, in fact, has a more severe climate than the rest of the country, but it also has much less fruitful pastures, which will not clothe themselves with grass, and on which man must do his part if he wants to ripen a harvest. It is, moreover, inhabited by a capable, energetic population, partly of Scottish origin, who brought from their homes in Scotland a knowledge of agriculture, and thus were spared the slow development from the nomadic condition. Here, in addition to flax, oats is the principal crop. Barley, the raw material for the national industries of whiskey and stout, is cultivated to a considerable extent in Tipperary and Wexford; but constant importation of barley is necessary, for the brewers have cause for complaint as to the uneven quality of the Irish barley.

The five types of farm which have been mentioned do not often occur as pure examples of their class. According as grass farming is combined with dry feeding its type becomes more modified in the direction of the agricultural farm. In County Roscommon and other places sheep pastures take the place of the cattle pastures. The breeding of swine and sucking

1 "Ireland, Agric. and Ind.," p. 307. 
pigs is also prosecuted almost everywhere. The West produces numerous though not often excellent fowl. There is everywhere a potato - field which in crop rotation often interchanges with oats and is intended for the sustenance of the owner. The importance of the potato in the food of the people is much less than in former times, but even to-day it takes a very prominent place. A good year not only renders possible a comparatively luxurious style of living but it also permits the rearing and sale of pigs, whilst a bad year in many cases means famine. Next to potatoes, cow's milk plays a great part in the people's diet.

6. As a sixth class we may perhaps mention certain farms, particularly in the West, which may be designated as household farms. A household farm in the strictest sense of the word is not possible in a country where the people have to pay rent. There the farmer must produce for the market. On many farms in the West however the occupants only produce oats, potatoes, milk, \&c., for their own use. The wool of the mountain sheep is spun and transformed into clothing. Any scanty surpluses achieved in this manner are sold, but are not sufficient to pay the rent. The rent, therefore, is in many cases paid out of some secondary source of profit, by fishing, tramping abroad for work, industrial activity, \&c., so that we may say in a certain sense that only the household needs of the family are supplied by the farm. 


\section{CHAPTER VI.}

THE IRISH TENANT AND HIS HOLDING.

IRELAND is a country of 'extensive' agriculture, and at the same time a country of small farms. The area of the holdings in 1902 amounted to :-

\begin{tabular}{|c|c|c|c|}
\hline $\begin{array}{l}\text { Area. } \\
\text { Acres. }\end{array}$ & $\begin{array}{l}\text { No. of } \\
\text { Occupiers. }\end{array}$ & $\begin{array}{l}\text { No. of } \\
\text { Holdings. }\end{array}$ & $\begin{array}{c}\text { Total Area. }{ }^{1} \\
\text { Acres. }\end{array}$ \\
\hline Under I & 73,352 & $\begin{array}{l}74,607 \\
62,864\end{array}$ & $\begin{array}{r}37,304 \\
88,502\end{array}$ \\
\hline $\begin{array}{r}I-5 \\
5-15\end{array}$ & $\begin{array}{r}56,233 \\
137,365\end{array}$ & $\begin{array}{r}62,864 \\
\text { I } 54,437\end{array}$ & I 88,592 \\
\hline $\begin{array}{r}5-15 \\
x-30\end{array}$ & $\begin{array}{l}137,365 \\
120,740\end{array}$ & 133,984 & $\begin{array}{l}1,544,370 \\
3,014,640\end{array}$ \\
\hline $30-50$ & 67,722 & 74,240 & $2,966,600$ \\
\hline $50-100$ & 54,3 I 4 & 57,568 & $4,317,600$ \\
\hline $100-200$ & 22,867 & 23,04 I & $3,456,150$ \\
\hline $200-500$ & 8,856 & S, I 47 & $2,815,450$ \\
\hline $500 \&$ upwards & 2,200 & $1,52 \mathrm{I}$ & $1,917,019$ \\
\hline Total & 543,649 & 590,409 & $20,350,725^{2}$ \\
\hline
\end{tabular}

From these figures it follows that 543,649 farmers are in possession of 590,409 holdings;

${ }^{1}$ The statements as to total area are based on calculations.

${ }^{2}$ Agricultural Statistics, I902, pp. I 8, 22. 
consequently almost 50,000 farmers have double holdings. ${ }^{1}$

A certain number of the holdings under one acre are potato plots held by town labourers, \&c.; there may even be a number of these included among the five-acre farms. From 5 to 30 acres we have 258 , I05 proprietors, who constitute $47^{\circ} 5$ per cent. of all the farmers; from I to 30 acres, 3I0,000 farmers, or $57^{\circ} 8$ per cent. The total area held by these $47^{\circ} 5$ per cent. is $22^{\circ} 4$ per cent. of the land of Ireland; $57^{\circ} 8$ per cent. hold only $23^{\circ} 3$ per cent. of the superficial area of Ireland ; that is to say more than 75 per cent. of the superficial area of Ireland is in the hands of the larger farmers, men working over 30 acres. If we consider that the small farms are to a great extent on bad soil, we shall easily perceive that the small farmer in Ireland does not lie upon a bed of roses. Matters are comparatively prosperous in the North. There the holdings are certainly small. In Armagh almost 70 per cent. of them are between five and ten acres; but the more advanced technical methods and the industrial character of the country render this smallness comparatively harmless. ${ }^{2}$ The number and size of the holdings have altered very much since the

${ }^{1} \mathrm{Ibid} ., \mathrm{p} .26$, note. If we find among the larger holdings more owners than holdings, this is owing to certain statistical double counts. [The figures for 1904 show 59r,224 holdings to 545,202 occupiers. Transl.]

${ }^{2}$ Agricultural Statistics, 1902, p. 34 . 
year I84I, the last census before the Irish famine. The number of farms was as follows :-

\begin{tabular}{|c|c|c|c|c|}
\hline $\begin{array}{l}\text { Year. } \\
\text { I } S_{4} \text { I }\end{array}$ & $\begin{array}{l}\text { I-5 Acres. } \\
310,43^{6}\end{array}$ & $\begin{array}{l}\text { Per cent. } \\
44^{\circ} 9\end{array}$ & $\begin{array}{c}5-15 \text { Acres. } \\
252,799\end{array}$ & $\begin{array}{l}\text { Per cent } \\
36 \cdot 6\end{array}$ \\
\hline $\mathrm{I} S_{5} \mathrm{I}$ & $88, \circ 8_{3}$ & I 5.5 & I9I, 854 & $33 \cdot 6$ \\
\hline$I 87 \mathrm{I}$ & 74,809 & 13.7 & I 7 I, $38_{3}$ & $3 I \cdot 5$ \\
\hline I $89 \mathrm{I}$ & 63,464 & I $2 \cdot 3$ & I $56,66 \tau$ & $30 \cdot 3$ \\
\hline I 901 & $62,8_{55}$ & I $2 \cdot 2$ & I 54,4 I 8 & 29.9 \\
\hline I 84 I & $\begin{array}{l}\text { 15-30 Acres. } \\
79,342\end{array}$ & I I 5 & $\begin{array}{c}30 \text { Acres \& upwards } \\
48,625\end{array}$ & $7^{\circ} \mathrm{C}$ \\
\hline I $85 \mathrm{I}$ & I 4 I, 3 I I & 24.8 & I 49,090 & $26 \cdot 1$ \\
\hline I 87 I & I 38,647 & $25^{\circ} 5$ & I $59,3 \circ 3$ & $29^{\circ} 3$ \\
\hline I 89 I & I 33,947 & $25^{\circ} 9$ & I 62,940 & $3 I^{\circ} 5$ \\
\hline I 901 & I $34,09 \mathrm{I}$ & $260^{\circ}$ & I $64,48_{3}$ & $3 I^{\circ} 9$ \\
\hline
\end{tabular}

Since I84I there has been a reduction in the holdings of -

$$
\begin{aligned}
& \text { I-5 acres of } \quad \ldots \quad \quad \ldots \quad \ldots \quad \ldots 247,58 \text { I } \\
& \begin{array}{llllll}
5^{-\mathrm{I}} 5 & , & \ldots & \ldots & \ldots & 9 S, 38 \text { I }
\end{array} \\
& \text { Therefore a total decrease of } 345,962
\end{aligned}
$$

There was, on the contrary, an increase in the holdings of-

$$
\begin{array}{rcrr}
\text { I5-30 acres of } \ldots & \ldots & \ldots & 54,749 \\
\text { 30 acres and upwards } & \ldots & \ldots & \text { I I } 5,8_{5}^{8} \\
\text { Therefore a total increase of } & & \text { I } 70,607
\end{array}
$$

If we take together the decrease in small holdings and the increase in large holdings, we get a total decrease of all holdings by 175,355 ; the total has fallen from 692,202 to 5 I 5,847 . In I $84 \mathrm{I}, 8 \mathrm{I}^{\circ} 5$ per cent. of all holdings were under 
I 5 acres; in I89I there were only 42.1 per cent. of these. There has, therefore, been a substantial diminution of small holdings and a substantial increase of large holdings. This movement was most pronounced in Connaught. There the farms of

Over 30 acres increased by ... $427 \% 7$ per cent.

But in Ulster only by $\quad \ldots \quad 36 \mathrm{r}^{\circ} 5$,

In Munster by

In Leinster by

‥ 245.3 ,

… II $94, "$

The great number of small holdings which is still maintained proves that the holdings which have disappeared were not utilised to raise small holdings to the dignity of middle-sized ones; they were rather welded into large farms. In this way the fact is explained that a large number of Irish farmers find themselves to-day in a far more prosperous condition than in the years before the famine; but that the circumstances of the owners of small holdings who still exist have not substantially improved.

Mere areas have a meaning only for those who have formed from personal observation an idea of Irish conditions. We can find in Connaught gigantic holdings, as far as area goes, on which, by reason of the poverty of the soil, a few miserable mountain sheep find a bare living. The following figures may serve as examples :- In the Poor Law Union of Belmullet

1 "Ireland, Agric. and Ind.," p. 3 I7. 
only 19.5 per cent. of the surface of the ground is occupied by agriculture and pasture:-

In Clifden

In Dunfanaghy

In Westport

$$
\begin{array}{llll}
\ldots & \ldots & 33.6 & \text { per cent. } \\
\ldots & \cdots & 30.8 & , \\
\ldots & \cdots & 3 I^{\circ} 9 &
\end{array}
$$

When we only regard extent, then Ulster seems to be the land of small holdings. Among I87,974 farmers there are 94,60I, that is to say just the half, whose holdings do not amount to more than I 5 acres, reckoning in both cases the holdings of less than one acre. But according to the taxation value there are out of 168,272 holdings only 35,370 of not more than $£ 4$. About one half of these, namely I4,9I2, fall to Donegal, the social structure of which resembles the western counties.

We therefore obtain a clearer general view if we group the holdings according to the value

\begin{tabular}{|c|c|c|c|}
\hline Valuation. & $\begin{array}{l}\text { Number of } \\
\text { Holdings. }\end{array}$ & $\begin{array}{c}\text { Percentage of } \\
\text { Holdings. }\end{array}$ & $\begin{array}{c}\text { Total Area. } \\
\text { Acres. }\end{array}$ \\
\hline$U_{p}$ to $E_{4}$ & I34, I 82 & $27^{\circ} 4$ & $1,360,000$ \\
\hline Over $t 4^{-1} 5$ & 201,309 & $4 I \cdot r$ & $4,760,000$ \\
\hline$" \operatorname{fI}{ }^{-30}$ & 78,044 & I 59 & $3,410,000$ \\
\hline,$E 30-50$ & 35,794 & 73 & $2,360,000$ \\
\hline,$£ 5^{\circ}$ & 40,972 & $8 \cdot 3$ & $6,8_{30,000}$ \\
\hline & 490 & 100 &,$\infty \circ$ \\
\hline
\end{tabular}
of their produce as it appears in the assessment of taxes:-

${ }^{1}$ Final Report on Local Taxation. Appendix, p. 34 . ${ }^{2}$ Census, i90 I. 
From this table it follows that 68.5 per cent. of all holdings which do not exceed the value of fI5 occupy 6.I2 million acres, or one-third of the total cultivated surface. 'Two-thirds of all the holdings occupy one-third of the land. I $5^{\circ} 6$ per cent. of all the holdings are valued at more than $£ 30$; they occupy 9.2 million acres or almost 50 per cent. of the total superficial area. The preponderance of holdings of small value is greatest in the IVest. In Connaught there were, out of Io9,359 holdings, 4I,439 of the value of $f 4$, and in Mayo 15,867 out of 32,732 . These I 5,867 holdings occupied 2 I4,000 acres of the Co. Mayo, which contains more than a million acres. The holdings of over $£ 50$, numbering about 700, alone covered an area of nearly 250,000 acres.

When we remember that the yearly valuation, as contained in the taxation assessment, was fixed on the basis of high prices for products, the picture of poverty shown by the number of small holdings is intensified. ${ }^{1}$ We may assume that all holdings under $£ 4$ and a large number of holdings up to $£$ I 5 are uneconomic holdings. If we combine the size of the holdings with their valuation, we may well conclude that 200,000 Irish farm holdings are uneconomic. That is to say, with the existing technical methods, the available capital and the prevailing market conditions, about 200,000 Irish farms

${ }^{1}$ Final Report on Local Taxation, p. I. 
are too small to support, even according to the low Irish standard of life, the families living on them, and to supply them with food, clothing, education and occupation. ${ }^{1}$

The worst of these deficit holdings, as I have called them in another place, are to be found in the so-called "congested districts." For the purposes of Local Government Ireland is divided into I 59 unions. These unions are sub-divided for election purposes into "electoral divisions," of which there are $375 \mathrm{I}$ in the whole of Ireland. By section 36 of the Land Act of I89 the Congested Districts Board was created, an authority whose duty it is to promote the lasting improvement of the backward districts in the West, and it received for this purpose an annual income of $€ 55,000 .^{2}$ The districts subject to it are selected according to the following rule: Where more than 20 per cent of the population of a county live in electoral divisions of which the rateable value gives a sum of less than 30 shillings per head of the population, these electoral divisions are deemed to be so-called "congested district counties." Such electoral divisions are to be found in the counties of Donegal, Sligo, Leitrim, Roscommon, Clare, Mayo, Galway, Cork (West Riding), and Kerry; altogether 9 counties with a total of $\mathrm{I}, 264$ electoral divisions. Of these 835 are not

${ }^{1}$ Journal Dept. Agric., December, 1903, p. 99.

2 "Ireland, Agric. and Ind.," p. 258. 
" congested " and 429 "congested." The total valuation of the 429 districts selected in $189 \mathrm{I}$ was, in I901, $£ 577,034$; the population 505,723 ; the rateable value per individual was therefore fI 2s. 9d.'

This designation of particular districts as congested districts is of course an arbitrary one. There may be electoral divisions the condition of which is much worse than in the congested districts, only these poor divisions do not form 20 per cent of the population of the county. There are in fact many such districts; the congested districts therefore contain only a particular section of the Irish population living on uneconomic holdings. The kernel of a deficit farm of this kind is always the potato patch, the dimensions of which vary according to the number of mouths in the family. It supplies the main article of diet; the surplus, if any, is used for pigs' food. The potatoes are grown in so-called "lazy beds," in broad drills separated from each other by deep trenches. In moist land these trenches serve at the same time for drainage purposes, especially where the potato field is situated on peaty soil. Formerly the tubers were simply laid on the bed and earth out of the trench shovelled over them ; They are now set in the ground. The work is frequently done with the spade, for the fields are

${ }^{1}$ Congested Districts Board Report, I903, Appendix 25 and 26 . 
often too small and too stony to admit of a plough being used; moreover, the farmer seldom has capital enough to possess a plough. The crop rotation is that oats generally follows potatoes, and in its turn makes way for potatoes again, a sequence which continues in tireless alternation so long as the plot continues to yield a crop. When the land is quite exhausted, another piece of pasture is broken up, which has hitherto been avoided for convenience' sake; the exhausted land is left alone and the grass grows on it of itself.

The land which is not used for potatoes and oats is pasture-sometimes lowland, sometimes mountain pasture-which is often used by a number of farmers in common. The bearing capacity of these pastures is established, and the unit of calculation is the "sum." A "sum " is the pasturage right of a certain number of stocl; ; whether these consist of cows, geese, sheep, or asses is at the option of the individual farmer, for there is a certain fixed standard of reduction between the various kinds of stock, so that every farmer can dispose his live stock according to these principles. There is not much dung produced on the farm, for no genuine stallfeeding exists. In addition to artificial manures sea sand, sea-weed, or peat soil are therefore made use of. At the seaside the chief manure used is sea-weed. The right to it is an essential part of most farms. Fuel material is obtained by cutting turf; the bogs of Ireland are so rich 
in turf that there is a lack of it only in a comparatively small number of badly situated places. The population lives from October to May for the most part on potatoes, milk, and tea. They sell calves and young cattle, pigs, and poultry. The cattle have often deteriorated, as the best animals are sold and the worst retained for breeding purposes. The pastures are frequently very poor, both from bad treatment and from being overstocked with animals; many of them serve to support nothing but the most easily satisfied Scottish mountain sheep. From May to October, when the old potato harvest is used up, the people live on American flour, or on maize meal, which is not only an article of diet, but also furnishes the principal fodder for the live stock on the farm. Oats are eaten ir the form of porridge, or given to the animals When the people supplement their scanty menu with bacon, it is of the worst American kind. The good Irish bacon made from their own pigs is much too expensive. The income from the sale of cattle and from other farming transactions is not sufficient to pay the rent, defray the taxes, make the usual offerings to the priest, and meet all necessary expenditure. Some additional source of profit is absolutely necessary. This is-(I) Work on neighbouring farms, for which, however, there is seldom a demand, as all the West is pasture land; there is a regular demand for labour only on the properties of the richest landlords. Much more 
important is (2) the work of the harvesters in England. According to Government statistics, I 7,566 labourers, or $3^{\circ} 9$ per thousand of the Irish population went in IgO3 to England; most of them came from Connaught, especially from Mayo. Amongst I3,530 Connaught men, 9,266 were from Mayo. About 80 per cent. of these migratory labourers are the sons and relations of land holders, but not themselves land holders; the other 20 per cent. are land holders. No less than 300 holders travelled from Connaught whose holdings averaged more than 20 acres. The railway statistics show a larger number of migratory labourers, namely 24,02I; but, as a number of double journeys made by persons who go twice in the year to England are here included, this statement is too high. Besides this migration to England there is an inland migration which is very hard to estimate from the more northerly counties to Ulster. If one goes in summer to one of the chief districts of these migratory labourers - for example, to Achill Island-there is scarcely an able-bodied man to be found in the large villages.

A third source of auxiliary profit is the fishing, which has above all things prospered considerably through the activity of the Congested Districts Board. Kelp burning may be mentioned as a fourth : this is the manufacture of iodine and soda from sea-weed, and was formerly a lucrative occupation on the west coast. It created the thickly scattered settlements which 
we still find along the west coast; but it is nowadays a declining industry, owing to developments in chemistry.

Domestic industries must be considered as a fifth kind of profit, especially the spinning and weaving of "homespuns," which flourishes principally in the mountain villages of Donegal. Stuffs to the value of $£ 700$ are often sold in the monthly markets of Ardara and Carrick. These homespuns are dyed (mostly with local vegetable products), and the patterns designed, by the people themselves, who often show remarkable taste and skill in this traditional industry.

The last and certainly not the least source of help which is at the service of the occupants of deficit farms, are the money contributions of their relatives who have emigrated to America. Without these various additions to the profits of farming they would always find themselves on the narrow border which separates a bare existence from famine. From time to time there is a famine, when the potatoes fail and the yearly income has to suffice not only for the months from May to October, but for the previous winter as well.

The type of deficit farm here described is not confined to the congested districts; there are frequently individual groups of such farms in other parts of the country which in other respects are quite flourishing. We may with

1 “Ireland, Agric. and Ind.," p. 395. 
certainty assume that there are from I 50,000 to 200,000 such and similar farms in Ireland. Ireland was originally covered with small farms; these are nowadays confined to from one-third to one-half the total number of Irish holdings. The occupants of these farms do not regard their holding as an agricultural business; they require turf, dwelling, potatoes and milk, and are willing to pay a rent for these, which cannot be met by the sale of farm produce. As long as this rent can be scraped together in some way by means of any occupation, it is all one to them where it comes from. Agriculture proper is beyond their ken. Two or three days in the spring are enough to get the fields into order; a little attention is necessary in the summer to keep the hungry sheep off; a couple of days are sufficient in the autumn to dig the potatoes and to harvest the oats. Though the ideal of these people is to increase their holdings they have no intention of running the plough across their fields. They hope rather to speculate in cattle as comparatively large cattle breeders.

It is scarcely possible to draw a definite line between uneconomic and economic holdings. It runs in general between 20 and 40 acres, hence the creation of such farms and the enlargement of small holdings to this area has become a political battle cry. The deficit farms are, economically, labourers' plots the owners of which have no opportunity for work, or they are in a technical sense grass farms whose owners 
possess neither cattle nor sufficient pasture. On other Irish holdings too the liernel of the farm consists in the potato patch; it is not very different from the deficit farms, only that the soil is better, that a more or less sufficient quantity of pasture is round about the potato patch, and that a certain amount of energy and technical skill are present. There is doubtless a certain tendency to increase the number of deficit farms. Just because the owners of the smallest holdings do not regard them as a farming concern, they are inclined to divide them up amongst their children or perhaps to sub-let them. The farm is expected to supply as many persons as possible with potatoes, milk and lodging, but not to afford facility for carrying on a proper farming business. Legislation has interposed great obstacles in the way of the sub-division of farms. On the large farms where farmers are by degrees beginning to work on economic principles this has not been completely in vain; on the deficit farms the tendency to sub-division will long continue. ${ }^{1}$

Agriculture then is the main industry of Ireland. To a great extent it is moving in wrong directions: the working system is 'extensive,' the technical method faulty. The farmer's money is in the bank and not in his farm. One who has an accurate knowledge of

${ }^{1}$ Fry Commission, Nos. $25,055,8,737,28,79$ I. 


\section{THE IRISH AGRARIAN PROBLEM.}

Irish agriculture has summarised his opinion in the following words :-

"A preponderance of uneconomic holdings, the want of working capital or of an inducement to invest in the improvement of land; the want of proper housing for the farmer and his family or for his stock; a large and steady increase in the area of second class pasture, which would yield four times more wealth if well tilled; the complacent satisfaction with the present system which relegates Ireland to the position of a ranch to supply store stock for British farmers to fatten; a too prevalent practice of selling the best and breeding from inferior stock; the almost complete loss in certain districts of the art of tillage; the want of a regular system of rotation; the aversion from doing more than the minimum to clean the land; the want of pride in the performance of farm work and in the arrangements about the homestead; the tendency to put off ploughing, sowing, and harvesting until the last moment; the small value that is put upon time; the want of recognition of the fact that the best and most productive manure that goes into the land is labour; all these and other causes combine to make and to keep Irish farming backward."

${ }^{1}$ Journal Dept. of Agric., December, 1903, p. I98. 


\section{CHAPTER VII.}

THE IRISH LANDLORD AND HIS ESTATE.

Even to-day Ireland is a country of large estates. The proprietory rights of the present owners go back in most cases to conquest. English conquerors overran Ireland at four different periods. First in May, II69, came a host of Norman-Welsh Conquistadors; then followed under Elizabeth the colonization of Munster, and of Ulster under James I, when the foundations of the present Anglo-Scottish colony in Ulster were laid. A further great outburst of colonizing activity took place under the government of Cromwell, which howvever came to a standstill under the Restoration. The fourth and last seizure of Irish land by conquest took place after the second or "glorious" revolution. In all these plantation schemes it was sought to establish not only large owners but also small peasants and labourers, an object which was partially attained, in Ulster only, by the "Plantation of Ulster." The present landowners of Ireland are to a large extent descendants of these colonists who were invested with the conquered land by King or Commonwealth. 
The great famine of the years I845-I85 I made bankrupt a number of landowners whose economic position had already been shattered. In the so-called "Encumbered Estates Court" and later in the "Landed Estates Court" a sort of liquidation court for the alienation of bankrupt estates was created. Io,034 estates to the value of $£ 54,000,000$ were sold through this court between I 849 and I 880, mostly at from 20 to 25 years' purchase. Many small Irish capitalists, such as shopkeepers and publicans, but also large insurance companies, were among the new purchasers to whom an absolute title of ownership was granted. ${ }^{1}$

It is not worth while to go in detail into the distribution of landed property in Ireland as set forth, though in a very imperfect manner, in the Irish 'Doomsday Book' of 1876 , for this arrangement of property is now passing away. I shall only point out that at that time about one half of the country was in the hands of about 700 persons.

The Irish estates of to-day may be divided into three classes. There are the large landowners who live on their English estates and merely draw an income from Ireland. These are of course absentees who only remain a few weels, if at all, in Ireland. As they are generally extremely wealthy and can afford to pay excellent agents, the condition of their property

2 "The Irish Landlord and his Accusers," p. 507. 
compares not unfavourably with that of the residents. The second class is that of large landowners resident in Ireland, who, with a large nominal income, are often anything but rich. To the third class belong local residents, small owners who by their bad economic position and the curtailment of their rents are obliged to remain continuously in Ireland. A fourth class of owners is formed by the 80,000 peasant proprietors created by the Land Acts, who will horvever have to be discussed in another connection.

Irish property has three important characteristics. It is divided property in many cases. The original feoffees set their land under agreements of the longest terms, often at a perpetual rent, to a middleman; they are therefore only rent receivers, whilst the actual rights and functions of the property belong to the middleman. Amongst others, Trinity College, the great Protestant University of Ireland, stands in this position.

The second essential point is that by far the greater number of Irish estates are bound by entails. Each occupier enjoys the property during life, but does not own it. That portion of the estate which goes beyond the usufruct bclongs to his sons, or. to such heirs as may be appointed by the family settlements. From this restriction formerly arose the inability to grant leases at long term. It was also impossible to sell the estates, for only the trustees of the heirs, 
and not the owner himself, could negotiate such a sale. "The "Settled Estates Act" of I 882 enables the owner to sell his estate, but he is obliged to invest the proceeds in the same restricted manner, in the form of securities tied-up for the wards. As trustee securities only yield from 3 to $3 \frac{1}{2}$ per cent. interest at most in England, a sale always means restriction to a rate of interest at $3 \frac{1}{2}$ per cent.

The third and most important point is the encumbered condition of many Irish estates. For decades the owners have lived beyond their means; they have carried forward as assets arrears of rent which could not be collected; and, as the law of primogeniture was in force, they have made settlements for life on other members of the family. The result was a heavy burdening of estates with mortgages. These mortgages are partly in the hands of members of the family; but also partly in possession of insurance companies, lawyers, \&c. The big Irish corporations, and especially ecclesiastical associations, have a considerable portion of their capital invested in mortgages of this kind. The first mortgages are generally excellent investments, for they are absolutely secure. As, however, a system of bonds and a mobilised mortgage system in general does not exist, there is no good market for such mortgages, and the rate of interest is very high -5 to 6 per cent. is by no means rare. The incumbrance of an income of $\hbar^{I}, 800$ with a settlement of $\hbar^{600}$ 
may be regarded as low. But if a fall in prices took place and rents fell by 33 per cent. the interest on mortgages would of course remain unreduced. If the total income dropped from

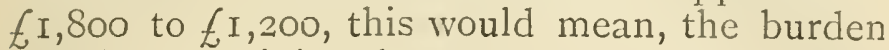
of debts remaining the same, a reduction of the net income by 50 per cent. The liquidation and conversion of debts was therefore often demanded by distressed Irish landowners. They have however never been able, till the Wyndham Land Act, to procure the creation of a financial organization for this purpose, although a reduction of the rate of interest from 5 per cent. to 3 per cent. would have reduced an obligation of $t 600$ to $\notin 360$.

The ancestors of the present Irish land owners were planted in Ireland with a view to civilizing the inhabitants, who laboured under truly primitive economic conditions. We cannot say that this task has been accomplished: The thousands of small farmers who were settled on Irish estates would have made the expenditure of immense sums of capital necessary, if the owner of the property had desired to give each of them a fully equipped farm. The owner seldom possessed the capital required for this object. Thus the burden of equipping his farm fell upon the farmer, who performed his task in a manner which was far from technically perfect. The landlord levied rent from the land; the farmer put all the capital into the land which was necessary to make it arable. 
64 THE IRISH AGRARIAN PROBLEM.

In this way arose a sort of divided property, "dual ownership," which gradually came to be recognized, first by custom, then by law.

On the whole, the ownership of large estates in Ireland is not carried on upon economic and businesslike lines. It is true that we may find almost everywhere large demesnes with park, garden, and home farm; but the landlord's house at the best was only an important centre of consumption, and very rarely the central point of a great scheme of management embracing the entire property. The administration of the estate is generally in the liands of an agent who carries on business with the farmers, collects the rents, and conducts the entire financial administration of the property, in which he is often controlled by the family lawyer. The business with the farmers is, in a great number of cases, a considerable task. On an estate recently purchased by the Congested Districts Board there are over 4,000 small farmers. The agent as a rule receives 5 per cent. of the rent receipts for his labour. As the majority of agents do not confine themselves to the administration of a single estate, an agent can be found for small properties as well as for large ones. The number of Irish agents must be about 400 .

The importance of the agent in Irish economics cannot be over-estimated. It depends upon his tact and business capacity whether the landlord lives in peace or in discord with his tenants, for Ireland is a land where nothing 
can be accomplished by principles, but where personal address means everything. The agent belongs to the gentry class. Beneath him, as his assistant, is the bailiff, whilst the home farm is managed by the stevard.

It is not my intention to give a detailed characterisation of the Irish landowner; this class is probably as much a mixture as in most other human occupations. But, more perhaps than other social groups, it has had to suffer for the sins of its useless members. It has distinguished itself in sport and in war; it has also showed its ability in the administration of England's colonies. It possesses, as far as the forms of social life are concerned, animation, grace, and natural talent to a high degree; but it has fulfilled its political and economic duties in Ireland ill enough, and during the great agrarian revolution which brought about its fall, it produced neither a policy nor a leader. 


\section{PART II.-IRISH AGRARIAN TENURE.}

\section{CHAPTER I.}

LEGISLATION FOR THE REFORM OF LANDLORDISM: THE LAND ACTS.

THERE are two principal forms of Irish land tenure in the nineteenth century. (I) Leases running for a fixed term of years; and (2) the more usual 'yearly tenancy,' terminable on six months' notice. In the year 1870 it was reckoned that out of 682,237 farms, 526,628 belonged to the class of yearly tenancies, while I 35,392 were leaseholds. ${ }^{\text {" }}$ The distinction does not arise, as one might have imagined, from a difference in the sizes of the holdings. Of the I55,609 leaseholds and fee farms, 82, I 45 were holdings of between one and fifteen acres; 63 , I54 were holdings between fifteen and thirty acres; and 9,310 were over thirty acres. ${ }^{2}$

As we have already mentioned, the capital of the farm is, speaking broadly, supplied by the tenant. Yet, as the Devon Commission had already pointed out, there are important excep-

"[There were 20,21 7 farms held in fee. Transl.]

2 "The Irish Landlord and his Accusers," p. 525 . 
tions to this rule. The Commission named twenty-two large estates on which the buildings and other standing equipment of the farm had been provided by the owners. ${ }^{1}$ Properties which were so equipped were named "English managed estates."

Where the whole capital of the farm was supplied by the tenant, the termination of the tenancy often meant the confiscation by the landlord of the capital invested by the tenant. The termination of a tenancy often took in Ireland the form of an eviction. During the years $1849-80,90,107$ families received eviction notices; of these, however, 2 I,340 were allowed to remain in their homes as caretakers, so that the number actually evicted was $68,967 .^{2}$ In the years I849-56 alone over 50,000 families were evicted. ${ }^{3}$ This was partly due to the famine, which led the landlords to consolidate holdings, while most of the later evictions took place in consequence of non-payment of rent long overdue; yet even in this period purely arbitrary evictions, whether on personal grounds or for the sake of consolidation of holdings, were not very uncommon. ${ }^{4}$

Even without any eviction it was possible for the landlord, if not to confiscate, at least to

${ }^{1}$ Lord Dufferin's "Irish Emigration and the Tenure of Land in Ireland," pp. 232-33.

" "Irish Landlord," p. 522 .

"Ibid, pp. 254 et seq.

"Cairnes, "Political Essays," p. 192. 
tax the capital of his tenant. This was done by raising the rent. In the case of every farm which is worked with a view to the market there is a more or less intimate connection between rent and the prices of produce. Thus the considerable rise of prices which took place between the years $1850-70$ occasioned a marked and in part justifiable increase in rents. The rich and aristocratic landlords seldom pushed to extremes the advantages offered them by the economic situation; on the other hand the smaller and poorer of the owners, as well as many of those who had newly acquired their property in the Landed Estates Court, demanded the highest obtainable rents. The competition for tenancies had always been keen. It is true that the conception of the net yield of a farm fixed for the purposes of taxation by Sir Richard Griffiths, the so-called "Griffiths" Valuation," lingered in the minds of the people as the true basis of all rents for all time. But the abstract sentiment did not translate itself into practice; on the contrary the sharpest competition prevailed almost everywhere. The population was indeed decreasing, but as the vacated holdings were amalgamated into large farms, so the number of holdings available for small tenants became fewer and fewer.

Ireland possessed $n 0$ system of town industries in which the population might have found employment, nor indeed had the people the training or the inclination for such industries. 
Moreover, the rural industries, such as kelpburning, home-rveaving and spinning, etc., while bringing, as an auxiliary employment, no inconsiderable return to those who practised them, increased their resources for paying a competition rent, and thus contributed to the general rise of rents. The agricultural labourers who do not form a strictly separate class in Ireland endeavoured always to get possession of small holdings or at least a patch of potato land. Their slowly rising wages helped to drive upwards the price of potato land and indirectly that of small farms. Finally, the remittances from America, which, between the years I 848 and I864, reached a sum of thirteen millions sterling, increased the effective demand for land and thus enhanced its price. ${ }^{1}$

The landlord was thus in a position to utilize the economic situation to the utmost and to demand a competition rent rendered especially high by the low standard of living of the Irish. In case the tenant declined to pay the increased rent he could be evicted, which meant for him the loss of all the improvements he had effected. Only in Ulster and on particular estates in the three other Provinces were matters otherwise. There the "Ulster Tenant Right" prevailed, the most important features of which were as follows :-

So long as the tenant paid his rent punctually

${ }^{1}$ Lord Dufferin, pp. 3 and 36. 


\section{TO THE IRISH AGRARIAN PROBLEM.}

he was not disturbed in his occupation. From time to time, however, there took place a revision of rents corresponding to the state of the market, but never utilising it to the full, so that the tenant never paid a pure competition rent (rack rent). It was permitted to the tenant to sell his interest in the holding, an interest made up by the improvements on the farm, and also no doubt by his 'goodwill.' In the case of such a sale, the landlord had, within reasonable limits, a right of veto. He had also a right of pre-emption, and when he desired to exercise it he paid his tenant a moderate price for his improvements. ${ }^{1}$

This system unquestionably promoted the economic life of Ulster. It led to a liberal expenditure of labour and capital on the side of the tenant, who was assured by it of the fruits of his industry; it did not, however, get rid of the unreasonable competition for land, which merely expressed itself in terms not of higher rents but of higher prices for the tenant right. Thus a great part of the capital at the disposal of the tenant could not be applied as working capital but had to be expended on the acquisition of the tenant right. Moreover the owner found the Ulster Tenant Right hampering him in the exercise of his proprietorial rights, inasmuch as it constituted a divided ownership; and cases were not uncommon in which progressively-

${ }^{1}$ Richey, "The Irish Land Laws," pp. 104-5. 
minded landlords bought out their tenants from their holdings. ${ }^{1}$

An enactment of the year I860 attempted to counteract the division of ownership by regarding the relations between tenant and landlord as pure matters of contract. In a further enactment it was sought to protect the tenant's interest by laying it down that improvements made with the consent of the landlord should give the tenant a right to compensation. ${ }^{2}$ Both Acts were failures, since a simplification of the law only led to a strengthening of the position of the landlords. The number of evictions increased. The following table gives the figures for 1866 and previous years :-

$\begin{array}{cccccccc}\text { Year. } & \ldots & 1860 & \text { I861 } & \text { I863 } & \text { I864 } & \text { 1865 } & 1866 \\ \text { Families evicted } \ldots & 63_{36} & \text { I,092 } & \text { 1,734 } & \text { I,924 } & 942 & 795^{3}\end{array}$

These evictions were largely necessary in the general interests of cultivation, for the enlargement of the holdings was urgently called for; but they always led to a great embitterment among the people, from which sprang agrarian

Lord Dufferin, p. 233.

2 Richey, pp. 47 et seq.; Bryce, "Two Centuries of Irish History," pp. 458-9; Barry O'Brien, "Parliamentary History of the Irish Land Question," pp. 103, et seq. I I3, II5; W. Neilson Hancock, "Two Reports for the Irish Government on the History of the Landlord and Tenant Question in Ireland."

s "Irish Landlord," p. 522. 


\section{THE IRISH AGRARIAN PROBLEM.}

crimes of the worst description. ${ }^{1}$ The number of these crimes was as follows :-

$\begin{array}{lllll}\text { I } 844-50 & \ldots & \ldots & \ldots & 7,95^{8} \\ 185 \mathrm{I}-60 & \ldots & \ldots & \ldots & 4,153 \\ 186 \mathrm{I}-70 & \ldots & \ldots & \ldots & 3,189\end{array}$

The decrease in number does not denote any real improvement, since the population had sunk from $6,900,000$ in $185^{\circ}$ to $5,400,000$ in 1870 . In the years I86I-70 there occurred no less than 294 agrarian crimes of violence, ${ }^{2}$ many of which were carried out with frightful brutality.

Meantime the era of the triumphant democracy had arrived in England, and it confronted the Irish landlord and his somewhat dubious contributions to civilization with extreme antipathy. The Manchester school agitated, above all things, against the rigidity of the system of ownership of the soil and the consequent monopolization of the land in the hands of a few proprietors; and through its leader, John Bright, it declared for the creation of a peasant proprietary. The wretched condition of Ireland, with its endless interchange of evictions and agrarian crimes, afforded ample material for the eloquence of the great tribune. There was at this time a political factor which inclined the public opinion of England towards

\footnotetext{
"Barry O'Brien, "Fifty Years of Concession to Ireland," II., p. 249 .

2 'Thom's Official Directory, I903, p. 705. 'The figures do not include those for the metropolitan police district.
} 
plans of reform for Ireland-it was the influence which the Irish who had emigrated to America had won in American politics, and which they now threw into the scales against England. In addition, numerous Irish colonies had settled during the famine years in manufacturing districts of England and formed there a dangerous proletariat. In America a national revolutionary movement had sprung up among the Irish immigrants, and an "Irish Revolutionary Brotherhood " was organised, which intended nothing less than an insurrection in Ireland accompanied by the landing of armed forces from America. Many of the Irish had obtained a military training in the American Civil War, so that the human material for the physical-force policy seemed to be ready to hand. The Fenians, as the revolutionaries were named, attempted various risings, of which the most notable was an outbreak in the year 1867 . Like all Irish insurrections in the Igth century, these ended in a few trifling skirmishes, which, nevertheless, were exciting enough to influence the public opinion of England. ${ }^{1}$ Thus it became possible for the English reformers to bring forward proposals for the prevention of fresh disturbances in Ireland. The road of agrarian reform which John Bright desired to travel led to the establishment of a peasant proprietary. Some tentative advance had already been made

'Morley's "Gladstone," II., pp. 28 I-297. 
on that road when, in the year r869, the Irish Church was disestablished. Bright still championed his old solution, but could not prevail against the many weighty arguments and prejudices on the other side; and it was decided to adopt a reform of the system of tenure based on the custom already described as the "Ulster Tenant Right."

The Act of Parliament of I870 by which this reform was carried out applied mainly to all yearly tenancies up to the value of $f$ IOo, though leaseholds under thirty-one years were also included. The Act contained four points of cardinal importance :-

(I.) It was settled once for all that a yearly tenant who was the subject of an arbitrary eviction should receive compensation for disturbance. He was excluded horrever from the benefits of the Act by any breach in the conditions of his tenancy, by non-payment of rent, and above all by sub-division or sub-letting of his holding without permission of the landlord.

(2.) A tenant on leaving was entitled to compensation for any improvements which he carried out.

(3.) The "Ulster Custom," "Ulster Tenant Right," was legally recognized.

(4.) Besides the above, the tenants on estates which came into the bankruptcy court received by the so-called "Bright clauses" facilities for the purchase of their holdings. It was the intention of the legislator to make arbitrary 
eviction so expensive a proceeding that no landlord would undertake it. He endeavoured indirectly to check the raising of rents by securing to the tenant who refused to consent to it the value of his improvements on giving up his holding. Moreover, he hoped, not only to diminish the number of evictions but also to promote the practice on the part of the landowners of giving longer leases.

But this Act, too, including the "Bright clauses," was a failure. Between the years I87I-I880 out of 6, I63 applications for compensation only $\mathrm{I}, 808$ were granted. The sum total of the compensations paid amounted to $f \mathrm{I} 47,304$, of which more than half $(£ 82,543)$ came to Ulster. ${ }^{1}$ The average sum paid in compensation was $£ 77$; but an evicted Irish tenant could not live on $£ 77$, since besides his farm he knew but one source of income-to put his money at interest in a bank. ${ }^{2}$ But apart from its technical defects what really impaired the efficacy of the Act was the economic situation at the time. The prices of the most important of Irish agricultural products rose steadily till I878; and this fact supplied the preliminary condition under which a rise in rent takes place. The farmer preferred to pay the increased rent rather than be evicted, and pocket the compensation. The rent-roll of the landlord rose and

1 " Irish Landlord," pp. 5 I0-5 2.

${ }^{2}$ O'Brien, "Parliamentary History," p. I 24. 
with it rose his outgoings. With splendid harvests and high prices the farmer did not feel the burden of the rent for a time. The Land Act had given him an interest in his farm which he used as a basis of credit. ${ }^{1}$ And so the good years brought landlord and tenant alike into a state of indebtedness which inevitably ended in bankruptcy.

The Act of I 870 protected the tenant only so long as he paid his rent. In 1878 there began a series of bad harvests, accompanied by a fall in prices caused by transatlantic competition. The harvest of I 879 was worth $f$ I0,000,000 less than that of 1878 -the potato harvest alone fell f6,000, $000 .^{2}$ The tenant could no longer pay the increased rent and the figures of the eviction statistics rose. There were evicted in

\begin{tabular}{cccccc} 
& & & & \multicolumn{2}{c}{ Families. } \\
$\mathrm{I} 877$ & $\ldots$ & $\ldots$ & $\ldots$ & $\ldots$ & 463 \\
$\mathrm{I} 878$ & $\ldots$ & $\ldots$ & $\ldots$ & $\ldots$ & 980 \\
$\mathrm{I} 879$ & $\ldots$ & $\ldots$ & $\ldots$ & $\ldots$ & 1,278 \\
$\mathrm{I} 880$ & $\ldots$ & $\ldots$ & $\ldots$ & $\ldots$ & $2, \mathrm{I} \mathrm{IO}^{3}$
\end{tabular}

As usual the evictions were followed by agrarian crime. The figures are:-

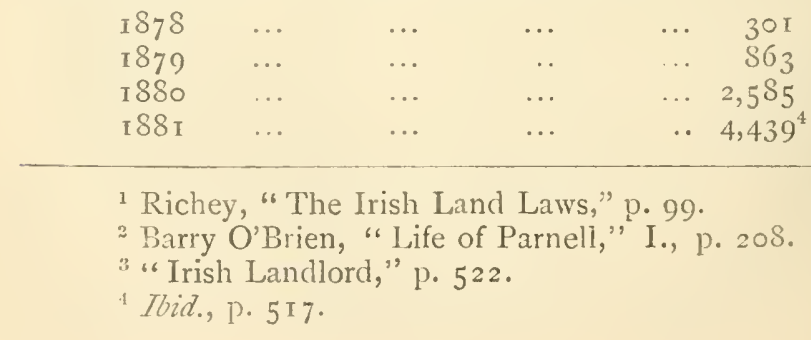


At the same time the Irish land question entered upon a new political phase. Until I870 tivo political movements ran side by sicle in Ireland. There was the constitutional movement under Butt, which sought by Parliamentary action to obtain a far-reaching measure of local government (Home Rule) and demanded above all things a reform in the system of agrarian tenure. This movement championed what are called " the three F's"-fixity of tenure, fair rents, and free sale. Over against this movement stood the revolutionary movement, which was guided from America, and which aimed at national independence, hardly thought of social reform, and preferred physical force to other methods of agitation. Under the influence of John Devoy and Michael Davitt these parties approached each other in $1878 .{ }^{\prime}$ The revolutionary party, whose backbone had hitherto been formed by a small circle of literary enthusiasts, took hold of the agrarian question in order to secure the interest of the masses. It hoped, through the destruction of the landlords, to drive out the English colonizing element from Ireland and to accomplish a nationalization of the land in which the primitive Celtic forms of land tenure should reappear. This amalgamation of the agrarian question with the national movement certainly gave the latter influence with the masses; but at the

'Barry O'Brien, "Life of Parnell," I., pp. 166.I69. 
same time it turned the national movement into a class question. The purely idealistic enthusiasm which in spite of their revolutionary methods had inspired many of the Fenians, now gave place to a more material passion. On the other side, the fight for agrarian reform was coloured by aims going far beyond that object. Land reform was demanded not in order to obtain it but to get possession of an inexhaustible material for agitation against English government. Out of this situation sprang that interplay in politics which must always be taken account of in the consideration of all Irish land questions. Agrarian reform for a large number of Irish politicians is not the ultimate aim; it is rather a means of keeping alive the claims of national independence. A final agrarian reform is therefore hardly desired, for if it were final the utility of the agrarian question as an engine of political agitation would be at an end. Thus it was alvays the policy of the Irish leaders to ask for more than they could get, to take what they could without making themselves responsible for it, and to direct the strength of the agitation with unabated intensity towards the objects still unattained. From time to time some leader, as for instance even Parnell, has yielded to the attraction of a positive and constructive policy, developed an inclination for reform, and sought to soften down the agitation; but immediately a storm has arisen against the advocate of compromise. This policy springs 
so obviously from the Irish national standpoint that one cannot but wonder again and again at the simplicity of the English politicians who with undiminished enthusiasm imagine that every new Irish Land Bill is to prove a 'final settlement.'

The movement of the year 1878 was ultimately organised as the Land League, founded by Michael Davitt. It found its leader in Charles Stewart Parnell. ${ }^{1}$ Its weapons were, in Parliament obstruction, in Ireland a fierce agitation. Agrarian agitation in Ireland had hitherto been generally accompanied by agrarian murders. The new movement did not favour this form of political persuasion, not exactly from sentiment, but because it had at its disposal a better method-that of the boycott. No landlord evicted any tenant in order to lose money by the transaction; the eviction took place in order that the land might be leased on better conditions to another and a solvent tenant. Now every man who ventured to take the land of an evicted tenant was boycotted at the instance of the League, i.e., he was cut off from all intercourse with his kind. The boycott was extended even into the church, for the clergy neither could nor would check it. ${ }^{2}$ The means

1 "Life of Michael Davitt," p. 2 I5.

2 "Life of Parnell," I., pp. 236 et seq. The term "boycott" comes from the name of its first victim, a Captain Boycott in Mayo, against whom this sentence of excommunication was first directed. 
for combating the boycott at the disposal of the State were then exceedingly feeble, for Irish juries in the ordinary process of law were accustomed to acquit all popular agitators. The proclamation of a kind of "state of siege" by bringing in a "Peace Preservation Act" is always difficult in England, more especially when a Liberal Government is in power. The Liberal Chief Secretary then in office, W. E. Forster, saw himself however compelled to resort to this step and thus immediately came into conflict with the Irish, with the Tories (who suddenly became possessed with a passion for freedom), and with the Radical wing of his own party. He held on his course in the policy he had begun and finally arrested the leaders of the League, a proceeding which was answered by the League with the proclamation of a general strike against rent (October I8th, I88I). The outbreak of this strike and the arrest of the leaders who had hitherto attempted to keep the movement within bounds led to an increase in agrarian crime, a fact which was hardly an unacceptable one to the imprisoned leaders, since it displayed admirably the futility of a policy of repression. English public opinion was systematically worlked up by Joseph Chamberlain-then head of the Radical party - against a policy of coercion, and since the crisis in Ireland did not pass away in a few months Forster's coercion policy was regarded as having failed. In May, I882, Chamberlain was in a position to bring about 
Forster's fall from office after he himself had effected with Parnell, then in Kilmainham prison, a sort of treaty of peace-the so-called Kilmainham Treaty. A few days afterwards, however, the new Chief Secretary, Lord Frederick Cavendish, and the Under-Secretary, Mr. Thomas Burke, were murdered by the "Invincibles" in the Phœnix Park. This crime showed more clearly than anything else how dangerous was the policy of the Irish leadersthat of inflaming by a fierce agitation an excitable people, and attempting at the same time to hold it back from deeds of violence. ${ }^{i}$

Yet the almost revolutionary agitation of the Land League made possible the continuance of agrarian reform. Clear-headed men had recognized that the simultaneous occurrence of falling prices and bad harvests had made the continued payment of the old rents impossible. Recognizing this, the Government attempted to check the increase of evictions. In I880 it had brought in a bill granting a postponement to tenants who were unable to pay their rents. When the Lords had thrown out this bill, Government appointed a Commission, the "Bessborough Commission," to go into the whole agrarian question with a view to further legislation.

${ }^{1}$ Compare on these points T. Wemyss Reid's "Life of W. E. Forster"; Morley's "Life of Gladstone," Vol. III., chap. 4 ; Barry O'Brien's "Life of Parnell," Vol. I. 
The Irish landlords however mistook the situation. They believed that the bad years would pass away, that the fall in prices hardly existed, that the whole land agitation was an artificial creation. Through their influence the Government proposals respecting arrears of rent were rejected by the Upper House and the poilitical crisis was thereby much intensified. It was not so much the ability shown by the League in conducting the agitation which rendered necessary the legislation of $I 88 \mathrm{I}$, as three bad harvests and the continuous fall in prices in the world-market combined with the lack of economic insight on the part of the owners of the soil.

The legislation which rested on the report of the Bessborough Commission followed that of the year I870 in so far as it addressed itself to a reform of the system of tenure, and only incidentally contemplated the creation of a peasant ownership. Its most important features are as follows :-

The Act empowers both landlord and yearly tenant to go before a Court and to demand to have a rent fixed by it. This Court may either be the County Court or the newly created Court of the Land Commission. It fixes a 'fair rent' which is to stand as the judicial rent for fifteen years. Landlord and tenant can also agree voluntarily on a fair rent and submit it to the Court, by which process it then becomes a judicial rent valid for fifteen 
years. Certain classes of yearly tenants, such as those of town parks, tenants of non-agricultural holdings, and graziers whose rent comes to more than $£ 50$ a year, were shut out from the benefits of the Act. ${ }^{1}$ Neither could the holders of long leases appeal to the Court to have their rents fixed; on the other hand future tenants were given facilities for enjoying the benefits of the Act. These regulations fulfilled the demand for two out of the three $F^{\prime}$ s, fair rent and fixity of tenure. Henceforth the tenant could only be evicted for non-payment of his rent or breach of the conditions of his tenancy. The Ulster Tenant Right was legally recognized throughout Ireland; the right of the tenant to sell his interest in his farm being allowed, albeit a certain right of veto was granted to the landlord. This involved the third $F$, the right of free sale. ${ }^{2}$

Besides this there were detailed regulations concerning the transformation of tenancies into proprietorial holdings. These we shall take account of in another place. The Land Act of 188I carried through the principle of dual ownership into its ultimate consequences; it was for the time however not available for all tenants, for many of them in consequence of the succession of bad years found themselves in arrears.

Section 59.

${ }^{2}$ This and the various subsequent Land Acts are printed by R. R. Cherry and Barton, "Irish Land Law and Land Purchase Acts." 


\section{THE IRISH AGRARIAN PROBLEM.}

Over I00,000 tenants were in such a position that in spite of the Land Act they could have been evicted. ${ }^{1}$ In order to open the benefits of the Act to them an Arrears Act was introduced, the effect of which was to wipe out all arrears for farmers paying less than $£ 30$ rent, who were willing but unable to pay, provided that they brought in one year's rent. The State provided another year; and the landlord, on receiving the two years' rent, renounced all further claims. The Irish landlord, who was usually so enthusiastic a champion of the rights of property, offered no resistance to this radical method of wiping out debts. It meant in fact that in place of so many years of unrealizable arrears he received two years' rent in hard cash. Of I35,977 claims for relief under the Act, I29,952 were admitted. The sacrifice made by the State amounted to $f 8$ I $2,32 \mathrm{I} .^{2}$

The Irish Party did not vote for the Land Act, for the majority of the Government was strong enough to ensure its adoption. They were thus in a position to reap the fruits of the reform legislation without undertaling any responsibility for it. ${ }^{3}$ They raised a number of justified objections to it. They urged that in view of the probability of a further fall of prices fifteen years was too long a term for a fixed

${ }^{1}$ O'Brien, "Life of Parnell," I., p. 340, note 2.

2 Shaw-Lefevre, "Agrarian Tenures," p. I 26.

3 O'Brien, "Ilife of Parnell," I., p. 294. 
rent; that town tenants and leaseholders should be included; that arrears (as it afterwards happened) should be wiped out. The working classes ought to obtain better dwellings, and the uneconomic holdings should be enlarged.'

The regular revolutionary party was altogether against the Land Act, for they realized the danger that the populace might be pacified. Parnell had found himself compelled to advise the tenantry to make only a slow and gradual use of the Act. In this way it was possible for him at the same time to bring some test cases before the new courts and to keep the national movement better in control and the revolutionary party in good humour.'

The Land Act of I88I was only the beginning of far-reaching reforms. The fall in prices of the chief agricultural products continued; it was particularly strong in the year 1885 ; the potato harvest failed in 1886 . On this the Nationalist Party demanded a revision of the already fixed judicial rents, a resettlement of the arrears question and the admission of leaseholders to the Act. The Conservative GovernmentGladstone had fallen on the Home Rule question-refused these demands. Immediately the agitation flamed up anew, and again the three factors were combined, the striving towards social reform, the desire to keep the national

1 Shaw-Lefevre, "Agrarian Tenures," p. I Ig.

2 O'Brien, "Life of Parnell," I., p. 302. 
movement going and the hope of forcing the Fenian party into the background." The outcome of this movement was the "Plan of Campaign." According to this plan the tenants offered to the landlord, as rent, whatever sum they thought good; if he rejected it they handed the sum over to a triumvirate who were to defray out of it the cost of the agitation. ${ }^{2}$ The whole affair was forced by William O'Brien against the will of Parnell.

Meantime the Government had appointed a new Commission, the 'Cowper Commission,' which had recommended a revision of rents and alterations in the existing tenure. When the Protestant farmers of Ulster, who were against Home Rule, became restless, the Government brought in new legislative proposals. These permitted the judicial rents already fixed by the Land Commission to be altered during the next three years in accordance with the fall in prices. $^{3} \quad$ Further, the leaseholders were admitted to the benefit of the Act of I88I and thus I50,000 new tenants were brought under its operation." The same thing took place in the

1 Morley's "Gladstone," III., p. 373.

2 Morley's "Gladstone," III., pp. 369-370.

${ }^{3}$ [A fall of prices takes place not only in consequence of foreign competition, but also of abundant harvests at home. The prosperity of the farmer, therefore, might sometimes constitute a claim to reduction of rent. The circumstance is one of these which display most vividly the economic absurdity of the dual system of land tenure as conceived at Westminster. -Transl.]

${ }^{4}$ Montgomery, "Land Tenure in Ireland," p. 179. 
case of owners of the so-called town parks. The ranks of those entitled to make use of the Act were still further increased in ISgI, when even tenants with perpetuity tenures were enabled to have fair rents fixed, provided the landlord refused his consent to a redemption of the rent-charge.

In the year I896 the first judicial term of fifteen years came to an end. A resettlement of the whole system was called for. It was effected by means of the Act of I8g6, which, while leaving the principles of the foregoing legislation unaltered, brought in numerous new features and technical amendments. On the basis of these measures-the Acts of I88I, I887, I89I, and I8g6-the greater part of the soil of Ireland is held at the present day, that is to say, by laws providing for fair rents, fifteen year terms, and free sale of the tenants' improvements and interests.

Of the 540,000 tenants in Ireland there were, from August 22nd, I88I, to March 3Ist, I902, 338,843 who had had first term rents judicially fixed. Of these, I96,377 rents were settled by process of law, I 42,428 by judicial agreement, 38 by arbitration. ${ }^{1} \quad 26,77 \mathrm{I}$ of these rents were of long term leaseholds. There are 20,000,000 acres in Ireland; judicial rents obtain over IO, I40,000. The original yearly rental of all these holdings amounted to $£ 6,900,000$. It was

${ }^{1}$ Land Commission Report, 1902, p. 69. 
reduced to $f 5,440,000$, or by 20.8 per cent. Thus more than half the surface of Ireland has been subjected to a first term judicial rent.' Moreover, many tenants who never went before the courts have felt the benefit of their decisions; the possibility of applying for a reduction has brought down the rents in corresponding proportion. ${ }^{2}$

In 1896 , after expiry of the first fifteen years term, the revision of the judicial rents began. The result was that by March 3 Ist, I903, second term judicial rents were fixed for $90, \$ 39$ tenants. The original rents, which had been reduced by the first decisions from $£$ I, 859, 000 to $£$ I, 5 I 2, , o were now brought down to $\ell_{I}, I 92,000$. The majority of the Irish tenants enjoy to-day, directly or indirectly, fair rents for fifteen year terms with the right of free sale of their interest.

Even to-day however the following classes are shut out from the benefits of this legislation :--

I. Tenants living on demesne lands, occupiers of grazing farms of over $£ I O O$ rental and those of non-agricultural or wholly urban districts. ${ }^{3}$

${ }^{1}$ [It must be remembered that of the 20 million acres in Ireland, 5 millions are reckoned as water, waste land, bog, etc. There are only about I 5 millions of productive land.-Transl.]

${ }^{2}$ By March 31st, 1903, the number of tenants whose rents had been fixed for a first term had risen to 343,370 . (Land Commission Report, 1903.)

${ }^{3}$ Act of 1896 , sections 5 and 6. 
2. The various classes of tenants who have been evicted by process of law but who were left on their holdings as 'caretakers.' The number of these is by no means inconsiderable. In 1888 there were I 2,387 persons evicted, but only I, I99 entirely turned out; in I896 4,806 were evicted and $66_{5}$ turned out.

3. The labourers. According to the last Census (IgOI) the number of male agricultural labourers came to I35,349, of the female to 4,967 , to whom must be added a large number of those reckoned as "general labourers." The labourer frequently receives a dwelling and piece of land as part of his wages; naturally, he has the use of the cottage and potato garden only during the continuance of his agreement. When the labourer rents a cottage and land from his employer who is himself a tenant enjoying the advantages of a judicial rent, it is open to the Land Commission to fix a fair rent for the labourer. In all 4, I44 such rents have been fixed. Frequently however the labourer has no land from his employer. In such cases the Poor Law Union is authorised to let a cottage and potato garden to the labourer under cost price and at a weekly rent. ${ }^{2}$ In I903,

${ }^{1}$ Report of the Fry Commission, p. 24.

2 Cf. various so-called 'Labourers Acts.' 
I5,090 of these labourers' dwellings had been erected, chiefly in Munster and Leinster. In many cases the labourer also rents land as 'con-acre,' i.e., he receives permission to take one harvest from a certain piece of land, for which he pays a very high rent; his methods of cultivation are generally very primitive and the land is deteriorated by them. When the same individual has the same piece of con-acre land year after year, his economic position is not very different from that of the labourer who rents a cottage and garden. It is difficult to ascertain the exact amount of land which is rented in this manner; we may, however, assume that a great part of the 74,607 holdings under one acre are labourers' land, to which the Land Acts do not apply.

4. The last class of tenants who do not enjoy the benefits of the agrarian reformand who indeed seldom need them-are the eleven months tenants. Section 58 of the Land Act of I88I laid it down explicitly that a temporary letting for purposes of grazing does not come under the Land Act. Therefore, if the grazing-letting is for less than one year, e.g., eleven months, a situation is created to which the Land Act is not applicable. The consequence is that the landowner has an interest in adopting this particular manner of letting any lands over 
which he has free control, as he can thus enjoy the benefits of free competition. The best grazing tracts of Ireland are let in this way at competition rents, frequently by auction. There is here no divided ownership, the lord of the soil is the sole owner. The tenant is often a capitalist stock-farmer on a large scale. In the West, these grazing tracts are frequently rented by residents in the towns, such as lawyers, doctors, hotel keepers, publicans, \&c., who carry on a little speculation in cattle as a subsidiary industry. 


\section{CHAPTER II.}

\section{LEGISLATION FOR THE ABOLITION OF LAND- LORDISM : THE LAND PURCHASE ACTS, I 869- I 896 .}

After the tenants who hold under judicial rents the most important class consists of those former tenants who, by having taken advantage of some one or other of the Land Purchase Acts, are in process of becoming owners of their holdings. The creation of peasant proprietorships was first practically attempted at the instance of John Bright, who in the year 1866 had proposed that five millions should be voted for the purchase of Irish estates in the open market. The State was to lend the money to the tenants at $3 \frac{1}{2}$ per cent. The tenants were to pay 6 per cent. on the loan, so that there would be a sinking fund of $2 \frac{1}{2}$ per cent. yearly.

When the Protestant Church was disestablished in the year 1869 , Bright obtained that tenants upon glebe lands should be offered their holdings for purchase, the State advancing three-quarters of the purchase money. In this way 6,057 tenants acquired property to the value

${ }^{3}$ Speeches of John Bright, Nov. 2, 1866. 
of $£^{1}, 674,000$. Later on, Bright again procured the insertion in the Land Act of 1870 of clauses by which two-thirds of the purchase money could be advanced to the purchasing tenant, while in the Act of I88I an advance of threefourths was authorised. These Acts had no great success.

The following table shows the number of tenants who purchased under the above Acts :-

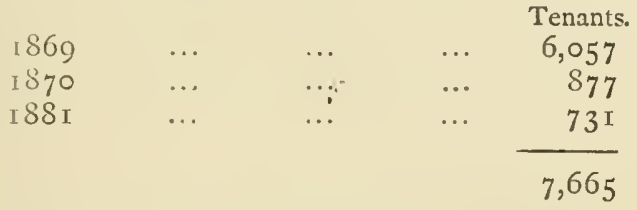

Apart from technical defects, the success of this legislation was mainly impaired by the following circumstances:-

The owner of the property had usually only a life interest in it, and could only sell if the interests of his successors were secured. As at that time there was no system of land registration in Ireland the owner was obliged before any sale could take place to prove his title with great particularity; deeds of grant and similar documents had to be hunted up in the archives, and subjected to an examination which cost much time and money. Moreover, the tenant was seldom in a position to produce the quarter of the purchase money which he was under all circumstances obliged to provide. In the year I882 a Committee of the Upper House, which 
criticised the Act of I88 I in a sense hostile to the Government of the day, proposed on these grounds that the Government should in future lend the whole of the purchase money. The interest was to be 3 per cent., and thus the amortization of the whole sum could be carried through in sixty-six years, if the tenant paid $3 \frac{1}{2}$ per cent. per annum, or in forty-six years if he paid 4 per cent. ' When a proposal so very advantageous came from the Upper House, it naturally did not tend to promote the success of the less advantageous proposals of the Act of I88 I.

The Irish Nationalist Party, speaking broadly, set up a peasant proprietary as their aim. The idea originally championed by Davitt of a nationalization of the land found little response in the party. In England on the other hand opinion was very much divided as to the desirability of setting up a peasant proprietary. When the Conservative Party, whose members controlled the above-named Committee of the Upper House, stood forward on behalf of such a policy, it was mainly with the idea of discrediting the land tenure policy of the Liberal Government. It did not mean that the prejudice against establishing small holdings had died out in England. It was feared, and not indeed without reason, that the Irish peasant proprietors whom it was proposed to create would

\footnotetext{
'Shaw-Lefevre, "Agrarian Tenures," pp. r 27-9.
} 
fall deeply into debt and would practise an extensive sub-division of their lands. It was also considered that the existing system of local administration which was largely committed to the great landowners vould prove irreconcilable with the creation of numerous small peasant ownerships. And there was the fear that large sums of money could not safely be lent to Ireland. A country which had just set on foot a great strike against rent might, not without justice, be regarded as an unreliable debtor. In spite of all, however, the idea of land purchase made way. In I884 the Liberal Chief Secretary, Sir George Trevelyan, brought in a measure according to which a sum of $f_{20}, 000,000$ was to be advanced for the purposes of land purchase, at the rate of not more than $£ 5,000$, o00 a year. Tenants who brought in one-fourth of the sum themselves were to pay off the other threefourths in forty years, their yearly instalments not exceeding the amount of their existing rent. Tenants who received the whole sum from the State were to discharge principal and interest by paying 5 per cent. per annum. This measure never became law. On the other hand, the new Conservative Government, which with Parnell's support had a majority, carried next year a Land Purchase Bill, the so-called Ashbourne Act. By this Act, which was passed in 1885 , a sum of $£ 5,000,000$ was voted for land purchase. The Act laid it down that owner and tenant should come to an agreement about the price; 
then the Land Commission had to sanction the transaction after investigation of the security of the holding for the sum proposed, and of the owner's title. If the Land Commission was satisfied on these points, the sum was advanced. The interest payable was 3 per cent. with I per cent. sinking fund, and the tenant became owner after forty-nine years. The landlord got hard cash, but one-fifth of the purchase money was held back as a guarantee.

Shortly afterwards the Conservative Ministry went out of office. Gladstone, who had meanwhile become converted to Home Rule, came back to power for a short period with the support of the Irish. With the Home Rule Bill which he now proceeded to bring in a land purchase bill was bound up, by which the landlord was enabled to dispose of his land at twenty years' purchase, and with this compensation to quit the inhospitable soil of Ireland. The sum which Gladstone held to be necessary for the execution of his scheme of general land purchase

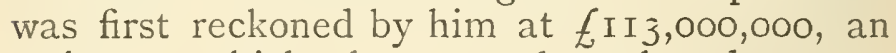
estimate which he soon brought down to f50,000,000.' Howvever, the whole Home Rule affair was a mere episode which came to an end with the return of the Conservatives to power. The $£ 5,000,000$ which had been granted by the Act of 1885 was soon used up. Another $£ 5,000,000$ was voted in 1888 , after an Act

${ }^{1}$ Shaw-Lefevre, "Agrarian Tenures," pp. I32-3. 
passed in 1887 had introduced some modifications into the system. This money too was quickly absorbed. The success of the Ashbourne Acts led at last to the great Land Act of I89I. Under this Act, a sum of $£ 33,000,000$ was to be advanced. The reason for choosing this sum was that the grants made by the central Government to the Irish Unions amounted to the thirtieth part of it; and therefore, by holding back these grants, the Government could compensate itself in case the sums payable for interest and sinking fund did not come in in due course. The maximum of $£ 33,000,000$ was an elastic figure, inasmuch as each payment which was received under the Act made possible a new advance of a corresponding sum. ${ }^{1}$ The reserve of one-fifth of the purchase money, a feature introduced by the Ashbourne Act, was retained. A further reserve against nonpayment of the instalments was created by holding back for five years certain new grants of the Imperial Government to local bodies, amounting to $£ 40,000$ a year. Furthermore, it was settled that the tenant should pay at least 80 per cent. of his existing rent in the form of interest and sinking fund. If his instalments came to more, the difference was retained by Government for five years. Four per cent. was to be paid for a term of forty-nine years, of which $2 \frac{3}{4}$ were supposed to be interest and the rest sinking fund; $\frac{1}{4}$ per cent. however was allotted

${ }^{1}$ Shaw-Lefevre, p. 143 . 
to form a fund for erecting labourers' cottages. The landlord was henceforth to be paid not in cash but in scrip, which ranked with Consols, and was called 'land stock.'

So complicated was this Act that for many causes, some of them being of a political nature, it was not a success. ${ }^{1}$ It was amended in the Act of 1896 . According to this the landlord, as before, was paid in scrip. The instalments amounted to 4 per cent.; $2 \frac{3}{4}$ interest, and $\mathrm{I} \frac{1}{4}$ sinking fund; the term for paying off the debt being shortened to forty-two years. Every ten years however there was a reduction in the instalments, the sum already paid being withdrawn from the capital and the 4 per cent. for the next ten years being only payable on the reduced capital. This was the so-called "decadal reduction "which it must be added had the effect of prolonging the period of the repayment from forty-two to seventy years. ${ }^{2}$

The results of all this legislation up to March 3I, IgO2, are shown in the following table:-

Under the Ashbourne Act-

No. of Loans. Amount of Loans. Acreage sold. Years' Purchase. $25,3^{6} 7 £ 9,993,000 \quad 943,000 \quad 17 \%$

Acts of 189 I and $x 8_{96}$

$$
\frac{3^{6,994}}{62,362} \quad \frac{10,809,000}{£ 20,802,000} \quad \frac{1,185,000}{2,028,000^{3}} \quad \underline{17.5}
$$

${ }^{1}$ Fottrell, "The Irish I and Act of $x 903$ Lxplained," pp. 4-6.

2 Fottreil, pp. 7, 8.

${ }^{3}$ Land Commission Report, p. $x \mathrm{x} 6$. The figures refer to loans issued, that is, advances actually made. In 1903 the number of purchasers under the Acts of $189 x$ and 1896 had risen to 42,436 , and the amount of the loans to $\mathrm{Ir}_{2}, 366,000$. 
Up to the date mentioned therefore over tivo million acres have been allotted to become in the nearer or more distant future the property of about 70,000 tenants for a sum of over $£ 20,000,000$. The total number of peasant ownerships thus created in Ireland is as follows :-

$\begin{array}{llllr}\text { Under the Acts of I869-188 I } & \ldots & \ldots & 7,663 \\ \text { Under the Ashbourne Acts } & \ldots & \ldots & 25,367 \\ \text { Under other Acts } & \ldots & \ldots & & \ldots \\ & & & & 42,436 \\ & & & & 75,466\end{array}$

In all these cases the State holds a kind of mortgage on the farm of the tenant, who becomes owner when this is paid off. This constitutes a material change in the economic position of the tenant.

Let us take a case in which a tenant has been paying a rent of $t$ Ioo a year. He redeems it, let us say, at eighteen years' purchase. The purchase-money is therefore $E^{\mathrm{I} 800}$. On this sum the tenant pays 4 per cent. for forty-nine years, i.e. $£ 72$. In other words, by the use of English credit he gets a reduction on his existing fair rent of 28 per cent. An Irish peasant therefore becomes an owner by the process of paying for forty-nine years a rent 28 per cent. less than that of his neighbour who is under a judicially fixed rent. The only advantage of the neighbour is that he can have his rent revised every fifteen years and is thus in a position to profit by a fall in prices. Such a fall would have to be a very 
considerable one for the non-purchasing tenant to come best out of the transaction.

Let us assume that of two tenants whose judicial rent has still ten years to run, one purchases his holding. He gets thereupon a reduction of 28 per cent. If his rent was $£$ Ioo he will have saved in ten years (not reckoning compound interest) a sum of $f^{280}$. If after this term a period of fifteen bad years should succeed, then the tenant who did not buy would have to get a reduction not only of 28 per cent. but another of I 8 per cent. in order to be on even terms with the other. The purchaser will have paid $£ 72$ a year for twenty-five years, or $f_{\text {, }} 800$ altogether, a good quarter of which belongs to sinking fund. The non-purchaser has paid fIOO a year for ten years, or $f$ Iooo in all. If for the next fifteen years he is to pay no more than a total sum of $£ 800$, then his rent must be reduced to $t 52$ a year.

Moreover under the system of decadal reductions there was the option of altering the instalments every ten years so as to correspond with possibly falling prices. When the purchaser paid $2 \frac{3}{4}$ per cent. interest and $I_{4}^{\frac{1}{4}}$ per cent. to the sinking fund he would have paid off his debt in $42 \frac{1}{2}$ years. If he paid $\delta 72$ in the first year he would in the case of the decadal reductions be paying at the end of 20 years a sum of $£ 52$ I 7 s. $6 d$. a year, so that he would then be as well off as the tenant under rent if the latter got a reduction of 47 per cent. Of course, as already re- 
marked, a tenant who took advantage of the decadal reductions had to pay his instalments for a longer term. ${ }^{1}$

However it must not be overlooked that land purchase has certain dravbacks. The tenant becomes a debtor to the Government which requires under all circumstances punctual payment and which proceeds with uncompromising severity against all the little devices and pretexts which were usual in dealing with the landlord. It grants none of the assistance which a benevolent landlord will from time to time afford to his tenant, nor does it take a particularly bad harvest into consideration. But the original rents which were capitalized by the tenants who acquired their farms since 1885 amounted to about $I \cdot 2$ millions sterling; the amount advanced was 2 I millions; 4 per cent. on these 2 I millions amounts to $£ 840,000$. The tenants have thus saved $£ 360,000$ a year; nor must it be forgotten that more than one-third of each yearly instalment is to be credited to sinking fund.

Under these circumstances the purchase policy became naturally an extremely popular one. This popularity however does not imply that the Irish tenant felt within himself the irresistible impulse to become a proprietor-it only proves that he found himself moved by a keen aspiration towards paying 30 per cent. less rent

1 House of Commons Papers, 1902, No. I86. 
than he did before. Naturally the purchase policy created what were felt to be severe hardships. On the one side there stands the tenant who by reducing his yearly obligations by 30 per cent. becomes an owner in from $42 \frac{1}{2}$ to 70 years-on the other side is the tenant whose rent is fixed by the court every i 5 years and who pays a great deal more in rent than the purchaser does in instalments. This danger was foreseen in the year I89I, when, as we have seen, a clause in the Purchase Act prescribed that a tenant's reduction on purchasing was not to exceed 20 per cent. for the first five years. Yet on the other hand it was desired to make the purchase policy popular and attractive. The hunger for property is not so keen with the Irish peasant as has been asserted; if that were really the case he would gladly go on paying his existing rents if he could thereby arrive at ownership in 49 years and be secured against any very excessive fall in prices by a Io-yearly or I5-yearly revision of rent. But it was necessary to offer him more attractive conditions; the difference between the judicial rent and the purchase-instalment had to be large.

A landowner whose rents amount to $£ \mathrm{I}, 000$ receives on sale of his property $t \mathrm{I} 7, \mathrm{OOO}$ or $E^{I 8,000}$ of capital-not reckoning here the costliness and technical difficulties of the sale. He had formerly to set off about $€$ Ioo against arrears, costs of collecting rent, etc., so that his net income was about $£ 900$. If he could invest 
his $\ell_{17}, 000$ in Argentine or Chinese bonds he would receive nearly $£ 900$ a year on security not much worse than that of Irish property and not involving its owner in the peril of being boycotted or murdered. But the landlord has only a life interest; he must invest the proceeds of the sale in trustee securities, i.e., in investments which will only bring in a return of 3 to $3 \frac{1}{2}$ per cent. $^{1}$ Now, $f$ I7,000 at $3 \frac{1}{2}$ per cent. will yield only $£ 559$; the landlord loses therefore nearly $£ 300$ a year. If the property is encumbered he is somewhat better off. If he has to pay $£ 5,000$ of the purchase money to his creditor, there remains to him $£ \mathrm{I} 2,000$; his income will then be £20. But if he has been paying 5 per cent. interest on the debt his former net income was only $f_{650}$ - his loss of income is therefore only $£ 230$. In consequence of the high rate of mortgage interest in Ireland, it is precisely the encumbered landlord who is least injuriously affected by a sale. In any case however a sale nearly always means a greater or less loss to the owner. Many a landlord who would gladly have sold has seen himself obliged on these grounds to retain possession of his property. Few owners sold except the very rich, who were not seriously affected by a reduction in their income, and those who were over the ears in debt. This financial effect of the

${ }^{1}$ Fottrell, pp. $5^{2-6}$, where also a list of trust securities is given. 
land purchase legislation was for a while somewhat neutralized by the fact that since I8g I the landlord was paid off in Land Stock. This payment in State bonds implied a bonus not visible on the surface of the arrangement. The vendor received nominally $f_{\mathrm{I}} \mathrm{Oo}$, while the prices on Exchange gave him $f_{107}, f_{108}$, or even $f_{1}$ I 4 . In days when stock was at I 4 the vendor obtained in this way a bonus of I4 per cent. The fall of Consols (to 85) of course transformed this premium into a loss and was one of the main reasons why land purchase came to a standstill in recent years. To this must however be added a multitude of bureaucratic obstacles originating with the Land Commission.

Thus Ireland, taken broadly, exhibits to-day two main types of tillers of the soil-those who pay a judicial fair rent for fifteen year terms and those who through the operation of the Purchase Acts are on the way to become owners of their farms. As the first Ashbourne Act became law in 1885 , it follows that the first proprietors will have paid off all their instalments in from twenty to thirty years. These prospective owners are paying, according to the varying terms of their purchase, instalments of interest and sinking fund less by 20 per cent. and over than the rents of their less favoured fellows, who console themselves with the silent hope that the time will some day come when the Irish tenant will have his land for nothing. 


\section{PART III-THE AGRARIAN REFORM OF 1903.}

\section{CHAPTER I.}

INSUFFICIENCY OF THE LAND ACTS.

THE creation of courts for fixing rents was in its time regarded as a socialistic experiment, for which different parties predicted the most different consequences.

Did the experiment succeed? Were the judicial rents really adjusted to the fall in prices?

The average rent-reduction in the years I88I--I 897 may be taken at 28.5 per cent. ${ }^{1}$ The fall in prices varied from 32.2 per cent. for flax, $20^{\circ} 8$ (oats), I7. I (butter) to I2.I for two-years old and $5^{\circ} 2$ for one-year old cattle; there was no decline in hay. ${ }^{2}$ Now in order to arrange for an automatic connexion between prices and rents one would have to ascertain how much of each product came from each farm. But even if we knew this, we should not yet be in a position to say whether a rent-reduction was fair or not. Say that the gross product of a farm is

${ }^{3}$ Fry Conmission Report, p. 23.

${ }^{2}$ Ib., App. A, p. I ; App. G, pp. 353-359. 
worth $f$ IOO, and that the cost of production is f40. There is then a surplus of $f^{6} 60$. If we divide it equally between landlord and tenant each will get $£ 30$. Now suppose that the cost of production remains the same, but that the gross value of the products sinks by 20 per cent., i.e. to $f^{80}$. There is now $f^{40}$ instead of $f^{60}$ to divide. The owner takes $\mathrm{f}_{2} \mathrm{O}$ - the half, as before-while he formerly got $£ 30$. His rent is therefore reduced by $£_{1}$ o, or $33 \frac{1}{3}$ per cent., while the fall in prices was only 20 per cent. ${ }^{1}$. Does the rent-reduction in this case stand in true proportion to the fall in prices?

Rent, in Ireland, is the sum which the owner of land receives for the use of it from the tenant. If this rent is to be fixed as a fair one by a court of justice, then that court must furnish a definition, showing what it regards as 'fair,' and it must indicate the methods by which a 'fair rent' is arrived at.

The Fry Commission pronounced such a definition. According to it, a "fair rent" is "the yearly sum for which the farm in the landlord's hands could be reasonably let from year to year, taking into consideration all the circumstances of the case in connexion with the farm as well as with the whole district; and assuming that the farm is let to a solvent and sensible tenant who hopes to make a profit by cultivating and not by selling the holding." 2

\footnotetext{
${ }^{1}$ Fry Commission, p. 33.

${ }^{2}$ To., p. 21 ; Evidence, 19,990 sqq.
} 
One must therefore know the productive power of the farm, one must estimate the value of the products, taking the state of the market, etc., into consideration, and from this one must deduct the cost of production. The surplus is to be divided, according to a formula which has yet to be ascertained, into the profit of the tenant and the rent of the landlord.

In Ireland this method is frequently very hard to apply. Of 486,865 holdings (I 892 ) there were only $\pm 27,098$ over 64 valuation. ${ }^{1}$ Most of these little holdings are not to be regarded as agricultural. If the occupier pays no taxes and takes no account of his labour the holding does not produce enough to support him. There is therefore no surplus to divide-the rent which is paid comes from some subsidiary industry. But does this mean that the land produces no surplus over the cost of production? Let us take the case of a farm rented at $£ 50$. The farmer can live comfortably on this and have another $£ 5^{\circ}$ as profit. Now let this farm be divided into ten, each of which pays $£ 5$ a year rent, the rents amounting in all to $£ 50$ as before. The ten tenants cannot live decently on these holdings, not to speak of making a profit. There is no surplus. They pay the rent-which their mutual competition probably sets higher than that of the single $t_{50}$ holding-out of other industries. It is the price which they are ready to pay for

${ }^{I}$ Fry Commission p. I9. 


\section{IOS THE IRISH AGRARIAN PROBLEM.}

their dwelling, their potatoes and their milk; and they earn it as migratory labourers, etc. This price, their rent, stands in no close relation to the products of the holding, the market prices of which have hardly any greater connexion with it, and very little of them is ever sold. The rentable capacity of these holdings, in fact, depends only to a slight extent on their products; it is rather an affair of the rentable capacity of migratory labour, of fishing and of spinning. But inasmuch as these subsidiary industries raise the rentable capacity of a deficit holding, they indirectly produce a rise of rent for the whole country.

A 'fair rent,' therefore, upon a deficit holding must be fixed upon other considerations than those which obtain in the case of true agricultural holdings. The deficit farms are to be found upon the worst soil, and, so far as markets are concerned, in the worst situation. Nevertheless when we take all the factors for an estimate into consideration, we find that a fair rent upon these farms must be exceptionally high. The competition rents before I88I were in fact arrived at on these considerations. Therefore according to a strictly logical definition of a fair rent the Courts would have to give the least reductions precisely in the places where the situation of the tenants was most pitiable.

The Courts, however, have neither set up an exact definition nor have they adhered consistently to one practice. Originally indeed in 
estimating the value of a farm they took more account of factors not strictly agricultural than was the case later on, when they were disposed to fix fair rents on the basis of the agricultural productivity of the holding. ${ }^{1}$ In the main it may be said that they did not solve the economic problems which the legislature had set them, and they even ignored certain regulations about which there was no doubt. Thus, the Commissioners frequently took account of an 'Occupation Interest,' i.e. the right of an existing tenant to hold at a lower rent than could be accorded to a new tenant. This occupation interest, which had no foundation in law, was allowed for up to 15 per cent. of the rent. $^{2}$ Thus no really just division of surplus took place between landlord and tenant. The capital value of an Irish farm is represented by the land, which is the property of the landlord, and the improvements, which belong to the tenant. In reckoning the net profits, the sum taken to start with was the amount realizable by the sale of the products. This gross profit was naturally diminished by the fall in prices. The whole loss of this fall was frequently laid upon the landlord. The interest on that part of the capital represented by the soil was lowered; the interest on the improvements remained the same. The first judicial reduction brought down the

${ }^{1}$ Fry Commission, p. I 8 .

2 Tb., p. 2 I. 
landlord's interest over all Ireland by a sum of E.5 millions. The income of the tenant remained, so far as one can see, the same as before. The standard of comfort has everywhere risen, bank deposits have increased, one never hears of abandoned farms. ${ }^{1}$

The sales of the tenants' interest in their farms-the so-called "tenant-right"-have in general shown no fall corresporiding to the fall in prices. In many cases the capital value of the tenant's interest has risen. It often happens that this rise stands in inverse proportion to the movements of the rent; so that we are led to suspect that the capital value of the rent-reductions caused by the fall in prices has not disappeared, but has been transferred from landlord to tenant. In any case the height of the prices for tenant-right, even where they have fallen, shows that the depreciation of the tenant's capital stands in no relation to that which has to be written off from the landlord's. In many places, especially in the West, the price of tenant-right goes to a dizzy height. While the value of the landlord's interest did not commonly go to more than 18 to 20 years' purchase of the rent, that of the tenant-right moved, e.g. in Gweedore, between 60 and 428 years' purchase. ${ }^{2}$ In the many thousands of cases which were brought before the Fry Com-

1 Fry Commission, pp. 26, 28.

2 Ib., App. C, p. 269. 
mission, prices of 20 to 30 years' purchase were very frequent. ${ }^{1}$ Of course the particular features of individual farms have their part in these results. Very large farms, for which there are not many farmers with large capital to compete, sell in Limerick for example for $4 \frac{1}{2}$ years' purchase, while medium-sized farms in the same district fetch 9 - I I $\frac{1}{2}$ years'.2

Cases in which the same farm has been several times sold, before and after the rentreduction, show frequently a marked increase in the number of years' purchase as well as in the sums actually paid-an increase which cannot always be explained by fresh expenditure of capital on the part of the tenant. ${ }^{3}$ It cannot be said that the rent-reductions have on the average brought down Irish rents too much, nor that they have transferred the landlord's interest to the tenant in the form of an increased tenantright; it is, however, tolerably clear that the rent-reductions have fallen almost exclusively on the capital of the landlord, and that the tenant's interest has not been diminished in like proportion. The effect of the blind competition for the land has been abolished in the case of the landlord, but the tenant can still profit by it in the appreciation of his tenant-right. When the

${ }^{1}$ App. C contains over 5,000 cases, mostly from the North. Among these are of course a number of exceptional cases of unusually high or unusually low prices.

${ }^{2}$ Fry Commission, App. C, p. 256.

${ }^{3}$ Ib., App. D, p. 326-343. 
tenant's interest in a farm is sod for $f, \mathrm{I}$, oo it matters nothing whether the purchaser pays f, 700 for the landlord's share and f, 300 for the tenant's, or $\notin 500$ for each.'

This unequal apportionment of the fall of prices, which bore unequally against the share of the landlord and that of the tenant, has had unfortunate consequences. The stimulus to combat the fall in prices by reducing the cost of production has been wanting; taling Ireland as a whole the cost of production, according to the Fry Commission, has remained unchanged. ${ }^{2}$ The Act of I88I took away from the sleeping partner the possibility of influencing production, while it took from the active partner the interest in increasing it, since his partner would share in the profit. ${ }^{3}$ When the co-operative movement began, some of the leaders of the Nationalist party, especially John Dillon, offered it the bitterest opposition. Higher returns were not

${ }^{1}$ Fry Commission, App. E, pp. 345-47. That the competition for land has not become exhausted is also clear from the prices which are paid for grazing lands, which are still in the landlord's hands, under the eleven months' system; as well as from the rents obtained by sub-letting to labourers, etc.

$216 .$, p. 24 .

${ }^{3}$ [One might add, would share to an extent which the tenant could never foresee and reckon on-there being no definite principle in the manner in which the profits of the farm were to be divided. The tenant, therefore, never knew how much of the fruits of his labour or enterprise he would reap himself, and how much would be allotted (at the next revision) to the other partner.-Transi.] 
wanted when the landlord, through future revisions of rent, might have some share in them. Indeed cases are not uncommon where the tenant has gone further still, and in order to secure himself the largest possible share in the returns of the farm has let the land-the landlord's part of the capital-run to waste before the fixing of a new rent. In cases where a wilful deterioration of the holding has taken place before an application to have a fair rent fixed, the application can be rejected by the court. But this power is not utilized. On the contrary, deteriorated farms are rented lower than well-cultivated ones. Two brothers divided a farm into two shares of equal value-the good husbandman got a rent-reduction from the courts of $7 \frac{1}{2}$ per cent., the bad one got I $7 \frac{1}{2}$ per cent. ${ }^{1}$

One cannot therefore say that the Land Commission has solved the problem of fixing a really fair rent. Properly speaking, it would have had to investigate, in the case of each holding, what part of the total capital was furnished by the landlord and what by the tenant. It would have had to inquire whether the landlord had not already by high rents appropriated a part of the tenant's property, or whether the tenant had not already been compensated by specially low rents for his expenditure of capital. A complicated balance must have been struck-a thing impossible, if only for the one reason, that the

1 Fry Commission, p. 22. 


\section{II4 THE IRISH AGRARIAN PROBLEM.}

parties rarely lept any proper accounts. In general it may be said that high and low rents were treated pretty much alike, so that a just landlord who had compensated his tenants for their improvements by low rents was much harder hit than the proverbial Irish landlord. The Land Commissioners have not been a success as administrators of a practical Socialism. They had at their disposal for purposes of comparison all the data of an economic system resting on free competition-data which they could gain by observation of neighbouring properties not subject to their operations, and by looking up the history of the rental of each farm they dealt with. These were the basis of their decisions. What they would have done without these data to go on is a question which baffles conjecture. $^{1}$

Yet the land legislation has contributed not a little to the attainment of a kind of social peace.

${ }^{1}$ Many of the imperfections of the Land Commission are explained by defective organization, and this in part was conditioned by the irregular rush of the tenants to have their cases settled. Thus in $1882-3$ there were $68,53 \mathrm{~S}$ cases to dispose of ; in $\mathrm{J} 886-7$ there were 7,020 ; in $\mathrm{I} 888-9$ they rose again to 28,767 ; in IS95-6 they sank to 4,077 (Land Com. Report, p. 69). Many details might have been altered by better organization. One must, however, agree with the judgment of the Fry Commission, that no improvement could leave the existing system "other than a complicated one, or free the fixing of fair rents and true value from the uncertainty which must attach to all figures arrived at by the estimate of an individual, and not by a scientific method of computation" (Fry Com., 1. 40). 
It has broken the domination of the landlords, and made arbitrary evictions practically impossible. The evictions which even in 1887 numbered 3,869 sank in 1893 to 1,018 and in I 896 to 695 ; the records of agrarian crime sank simultaneously from 883 to 380 and 25 I. $^{1}$

An enduring peace was, however, not to be looked for. Every fifteen years at least the parties meet each other before the courts, and there strive with all the means in their power over the division of an ever-diminishing surplus. The judge who has to decide between them produces, it may be, a correct average result; but even where thousands of errors, by mutual compensation, bring about a true average result, this abstract equity does not bring much comfort to the individual victims. If ever a Commissioner ventures to raise a rent, a storm of indignation arises. It has become perfectly clear that the land courts may work away so long as all idea of a general raising of rents is barred out, but should anything of this kind ever take place, it would bring about an agrarian revolution against the State and its courts.

As land legislation has reduced the landowner almost to the position of a mortgagee, so it has brought the relations of the tenant to his landlord into a condition which is neither one of vassalage nor of a true co-partnership, but that of a debtor. The law has protected him

${ }^{1}$ Fry Commission, App. 


\section{II6 THE IRISH AGRARIAN PROBLEM.}

from arbitrary eviction and from increase of rent, but has not freed him from the obligation of paying rent, and if he cannot pay it he loses all his rights as a tenant. He need not be evicted, for the Act of 1887 makes it possible to retain a tenant who has not paid his rent as a lind of manager or caretaker; but his holding goes back into full possession of the landlord, who lets it to him for eleven months at most. In I 889 the tenants who lost their holdings in this way numbered 7,238 ; in 1897 there were 4,019 ; in I 902 there were 2,694 . Very few of them were really evicted ${ }^{1}$ - but all of them lost the privileges which it was the purpose of the land legislation to secure to them.

Thus the working of this legislation must be pronounced to have been in many respects unjust, ineffective, and incomplete.?

1 See above, p. 67 .

2 In Ulster the landlords have in many places sought to utilize the Act for the object of getting rid of the Ulster Tenant Right. Russell, "Ireland and the Empire," p. I60. 


\section{CHAPTER II.}

INSUFFICIENCY OF THE LAND PURCHASE ACTS.

UPON the legislation relating to the sale and purchase of land, a much more favourable judgment must be pronounced. None of the gloomy prophecies about the working of a system of peasant proprietorship have been fulfilled. The purchasing tenants have punctually discharged their yearly instalments. Nothing in the nature of a strike against the payment of these instalments has ever been heard of. In I 897 there were only about roo tenants in arrears. ${ }^{1}$ The purchasers have not shown themselves to be irresponsible and careless managers, they are not more heavily in debt, nor are they worse cultivators than the non-purchasers; politically they may probably be reckoned among the more conservative elements of Irish life. ${ }^{2}$ They have unquestionably shown the practicability of establishing a peasant proprietary in Ireland. They have cut the ground not only from under the

${ }^{1}$ Fry Commission, App., pp. 6 and 7 .

2 Report by Mr. IV. F. Bailey, Legal Assistant Commissioner, of an Inquiry into the present conditions of Tenant-purchasers under the Land Purchase Act, I903. 
prejudices of the English, but also from under the Irish agrarian Socialists, represented by Michael Davitt, who wished to link on the new system of land-tenure to early Celtic institutions. For a moment, the ideas of Henry George stood, as watchwords of a policy directed against peasant proprietorship, in the foreground of public interest. The politico-economic realism of Parnell's mind repressed them at the time; the success of land-purchase in Ireland makes their revival for the next few decades improbable. ${ }^{1}$

It might be objected on the other side that the peasant owners already created are not typical of the class. The greater number of the holdings investigated by Bailey (10,076 out of 14,813 ) were situated in Ulster where rather exceptional conditions prevailed. Only the tenants of the wealthiest or of the most encumbered landlords have, as yet, been made owners. The former class have bought under excellent conditions; the latter have never had the duties of a landlord fulfilled towards them, so that they are economically strengthened by his abolition. At the bottom of this argument lies the not unjustified view that many of the Irish tenantry are not fitted to be owners, and that the number of such is greater than present experience would lead us

${ }^{1}$ One might draw an interesting parallel between those Irish Nationalists who champion the communal clan-system of the Celts, as the ideal system of land tenure, and the Russian Sklavophils or Pan Slavs, who have idealized the Mir. 
to suppose. It also includes the truth that the success of the peasant proprietors is not to be ascribed to some magical powers evoked by the possession of property, but to the very sober fact that the purchaser pays every year some 25 per cent. less than the non-purchasing tenant. On the popular side, this factor is regarded as the grand advantage of the land-purchase policy: it is the true policy because it has reduced the obligations of the tenants by 25 per cent. But in any purely scientific consideration of the subject it is precisely this which raises a doubt as to whether the creation of a peasant ownership is really answerable for the remarkable results which are witnessed.

On this account also the continuance of the system of rent-fixing has become impossible. There is not the slightest reason, in principle, why the tenants on the Dillon estate should become owners of their holdings by paying 20 per cent. less rent than their neighbours on the property of Lord de Freyne, who refused to sell. ${ }^{1}$ That also was the opinion of Lord de Freyne's tenants, who asked for a reduction of rent to the

1 The Dillon estate of 93,000 acres gross, with 4,500 cottier tenants, was purchased in 1899 by the Government (Congested Districts Board) to re-sell to the tenants. While the extensive improvements which, as usual, preceded the apportionment of the holdings, were being carried out, the tenants were employed as hired labourers; so that their condition contrasted with that of their neighbours, not only by reduced rents but by inconings of hard cash. 
same figure, and met the refusal of the demand by a strike against rent.

The United Irish League seized upon this contradiction between the two systems of agrarian reform. This organization was formed by IVilliam O'Brien in the year I898, and, like the Land League and the National League, spread itself over the whole country. Its practical object was, in the first place the revival of the land agitation, and afterwards the reunion of all the Irish patriots, among whom, since Parnell's fall, bitter contentions had prevailed. The principal aim of the agitation was to obtain the partitioning of the great grazing farms among the cottiers occupying the small and uneconomic holdings which bordered on them. The agitation was directed in the first instance against the graziers. But since these offered the landlord higher rents than the courts would probably have sanctioned, it was not to be expected that he would surrender the grazing lands over which he had still full control, and allow them to be partitioned. The boycott was first tried; it was sought to put a stop to the business of cattle-dealing. But as the results attained were not adequate and a new judicial decision made agitation and boycotting dangerous a movement was set on foot for the partitionment of the grazing ranches by compulsory expropriation.

This cry for the compulsory expropriation of the large stock-farmers gradually swelled into one for the compulsory expropriation of all landed 
proprietors. Almost all the estates whose owners were, under the existing conditions, inclined to sell, had by this time changed hands. The remaining landlords declined to sell, and thereby condemned their tenants, who desired to buy, to the payment of some 25 per cent. a year more than their neighbours. ${ }^{1} \quad$ Those who resented this state of things most bitterly were the Protestant farmers of Ulster, the very men whose qualities were best calculated to ensure their success as peasant owners. But, because they had never taken part in the agrarian agitation against their landlords, and because the latter were mostly in solvent and easy circumstances, it was just in these quarters that the outlook for further transactions in land purchase seemed particularly slight. The political leaders of the Ulster farmers, especially T. W. Russell, therefore, caught up the cry for compulsory expropriation with enthusiasm, a proceeding which powerfully influenced public opinion, for Ulster, Unionist in sentiment, had always demanded agrarian reform for its own sake and not with any object of stirring up the slackening agitation for the national independence of Ireland.

${ }^{1}$ [To put this quite accurately, it should be said that they declined to sell at any prices which the existing Land Courts would sanction, or which the existing purchase-system would enable the tenant to pay off at any appreciable reduction on his rent. The Courts demanded an extravagant margin of security for advances.-Transi.] 


\section{CHAPTER III.}

A NEW DEPARTURE.

Since 1885-6, the English Liberal Party has been in alliance with the Irish on the policy of Home Rule, i.e., of the granting of a system of parliamentary self-government. The Conservatives, on the other hand, held fast to the Union with England, and had as a Unionist Party gained their greatest triumphs. They refused the political demands of the Irish Nationalists; but recognizing justly that a purely negative policy is in the long run no policy, they had sought with a good will to comply with Ireland's desires in the economic sphere. Moreover, it is always well to be on good terms with a party eighty strong; no one can tell how the next elections may fall out.

This policy was called "Killing Home Rule with Kindness." 1 The principal champion of it was Mr. Gerald Balfour, whose brother, Arthur Balfour, had already inaugurated it. With the

${ }^{1}$ [Not of course by its adherents, who always described it as a policy of sympathy and justice towards Ireland, called for by the social and historical circumstances to which they attributed the Home Rule demand.-Transl.] 
former it was much more than a move in the game of party-politics. It was the outcome of a genuine conception of social reform. The Irish took his gifts with thanks; but the very earnestness which he carried into his work contributed to make him unpopular. It was seen that he had set his mind on real reforms, and that he inwardly despised the parliamentary manœuvrings of his opponents, for whom the political movement was an end in itself, just as reform was to Balfour. His work will therefore endure, but it will not be recognized until two or three of his successors have been likewise greeted as leaders of reform, and likewise held up as heartless tyrants to the hatred of the Irish people.

His successor, George Wyndham, continued the policy of conciliation. A brilliant causeur, one whose charm is liard to resist, an artistic nature, to whom form appears the main attraction-one, however, whose intellect, notwithstanding its spontaneity, coolly takes men's measure amid the surge of personal and social forces-Wyndham lnew how to champion the conciliation policy as if it were a matter of heartfelt personal concern, and the Irish blood which flows in his veins makes his line of action all the more intelligible.

He began his work under auspicious circumstances. On the throne sat a King whose heart was set on the contentment of Ireland. The Premier was Arthur Balfour who possessed a 


\section{I24 THE IRISH AGRARIAN PROBLEM.}

thorough knowledge of the country. As Chan cellor of the Exchequer Ritchie had succeeded the energetic but parsimonious Hicks-Beach. Chamberlain had, as yet unnoticed by the public, begun to transform the commercial attitude of the Unionist party - a circumstance which might easily weaken it, and in the case of new elections render it dependent on the votes of the Irish, who had already come forward as a prop of the Conservative party in the case of the Education Act. The Irish, it is true, had lately formed a new organization for themselves in the United Irish League; but agrarian burdens were no longer oppressive enough to raise the popular feeling to fever-heat, nor was agitation so dangerous as it had been some years before. ${ }^{1}$

${ }^{1}$ In rgor the House of Lords, through its decision in the Taff Vale case, had made it possible to hold the Trade Unions legally responsible for the acts of their officials. The Irish organizations for agrarian agitation were modelled, in principle, on the Trade Unions, and were defended by the same arguments as those which were used in their time to defend the Unions. There are, however, certain differences between an industrial strike and a strike against rent. The workingman who strikes gives no labour and receives no pay; the Irish peasant, however, refuses to pay rent for the land which he has already tilled, and regards his eviction for nonpayment of rent as an act of the bitterest injustice. Since the decision in the so-called Tallow case, the practice of boycotting has involved serious legal consequences. The defendant was condemned to pay to the plaintiff, whom he had injured by causing him to be boycotted, damages to the extent of $£ 5,500$ (March, r903). 
Moreover, the United States did not take the same interest as formerly in Irish affairs; their relations to England had grown much friendlier; their contributions to the Irish Parliamentary Fund could not, in spite of the collectionmissions vigorously undertaken by Irish politicians, be raised to the old figure. The breach which Parnell's fall had made in the Irish party had never been fully healed, loudly though the unity of the party was now proclaimed. Personal bitterness between the various fractions had increased in proportion as the differences on matters of principle grew more insignificant. The great opportunity, longed for by generation after generation, when England should be entangled in a dangerous foreign crisis, had passed away unutilized. The deeds of the Irish Brigade in the Transvaal war had done no serious harm to the position of England, while the Irish regiments in the British army had done more than their duty, and the leaders of the Celtic people had been wise enough to give to the cause of the Boers a purely moral support.

The Irish landlord too had become a wiser man. He saw that his rôle as a feudal magnate had been played to the end. He shuddered to think of the moment when, at the end of another fifteen years' term, the Land Court would again reduce his rent. That Ireland must become a peasant-land has long been clear to all eyes. Already, in the year I 898 , Gerald Balfour had drawn the necessary administrative conclusions, 
and created a system of local government resting on the peasant and tenant classes, so that in this sphere too the landlord party was spoiled of its traditional authority. The resident proprietor was thus deprived of his last remaining opportunity for active work in his district, since he could only sit in the local Council by the votes of the tenantry, and he can only be elected if he subscribes to the nationalist programme of legislative independence for Ireland. So far he has not done this, because Home Rule meant danger to his property. When this danger has passed away by the sale of his lands, he will be free to take part in at least the local life of his country; and then a national sentiment may easily arise in his mind. In the past he was always national in feeling, so long as he did not see his interests threatened by the masses of the Catholic and Celtic democracy. But he could not sell his estates unless he received a higher price than that heretofore offered, and this higher price the tenant, who is inclined towards land purchase only in so far as it means a reduction in rent, was not inclined to pay.

By the downfall of the Liberal Party in $\mathbf{I} 895$ Home Rule was, for the immediate future, put out of the range of practical politics. The Conservative Government was ready to make all kinds of economic concessions, but friend and foe alike knew that for the time being Home Rule was out of the question.

This pause in the great, decisive battle was 
utilized by Horace Plunkett, ${ }^{1}$ then a Member of Parliament, in order to focus public discussion on a policy which he had hitherto been pursuing on a smaller scale. For a long time he had been endeavouring to introduce into Irish agriculture the various forms of co-operative organization. Though he was not acquainted with the systems of agricultural co-operation on the Continent, he had been led to follow this path by his familiarity with the needs of Ireland, and by the practical experience of business which he had gained in America. He lacked both of the qualities with which Irishmen, whether of the opposition or the government party, are generally endowed-the fiery rhetoric of the popular tribune, and the ambition of the place-hunter who seeks to make some lucrative little post his own. On all sides, therefore, he was met with the justified mistrust of those on whose accustomed orbits of motion he began to exercise an incalculable and a disturbing influence. He had however got together a little company of enthusiasts from both camps, and had at last, by sheer persuasiveness, formed a committee composed of leaders of the landlord interest, of the tenants, and of the industrialists of Ulster. This body was called the Recess Committee, and its business was to formulate an economic policy for Ireland. ${ }^{2}$ Its next aim was

${ }^{1}$ Now Sir Horace Plunkett, K.c.v.o., and Vice-President of the Irish Department of Agriculture.

2 Sir Horace Plunkett, "Ireland in the New Century," Part II. 
the formation of a Ministry of Agriculture and Industries for Ireland, which should create and spread through the country the agricultural instruction urgently needed both by individuals and associations.

Plunkett's policy had shown once for all that a combination of all the political factions in Ireland is possible. ${ }^{1}$ He was cried down from all sides because he wished to be a practical Irish patriot, without favour for any particular class or religion. He had survived this opposition, and had called into life a movement supported by all circles in the country. He had also shownand he was the first to show-that a war of classes is not necessarily the sole meaning of all politics in Ireland, and that it is not, in truth, a national policy at all. But he did more than this. He showed that the popular policy, which demands new legislation every five years in order to divide up the surplus of agricultural profits according to some new arrangement, is not sufficient to make the country prosper. Ireland

${ }^{1}$ A combination of all parties had previously taken place in connection with the Financial Relations question. A Royal Commission had found that the indirect taxation of beer, spirits, tea, and tobacco weighed more heavily on Ireland, per head of the population, than on England and Scotland. Thereupon there arose a short-lived but clamorous agitation which demanded a repayment of the capital robbed from Ireland, and which taught its adherents to believe that the excessive taxation of alcohol, tobacco, and tea was the cause of the economic backwardness of the country. 
must rather aim at producing more than she does, and producing it more cheaply. Through her lack of capital and of technical training this can only be done by means of co-operative associations. Only by co-operation can the methods of modern production be made available for farmers who, at best, are only just above the rank of cottiers. The Irish peasant must raise the productivity of his holding by means of cooperative organization, and must give up trusting solely to the gains, in the way of land legislation, which can be won for him at the game of politics. In a country so undeveloped as Ireland it was surely the duty of the State to promote production, but it could only fulfil this duty with success when the producers also bestirred themselves.

In 1899 this policy had led to the creation of the Irish Department of Agriculture, and on the other side had by 1903 brought about the establishment of over 800 co-operative associations with a membership of 80,000 and a turn-over of two millions sterling. But it had also put the Irish problem in a new light before the English people. Here for the first time was an Irish movement which was ready to embrace all classes, and which had no essential hostility to any person-for the complaints of the small Irish shopkeepers naturally went unheeded in a country where co-operative institutions were so highly developed as in England. Here was a movement which demanded from Parliament no new division of the yearly surplus, but simply aimed 
at increasing that surplus by one's own exertions. Ireland, for the first time, seemed to wish to set to work, and to wait no longer for the legislative miracles which every new Government promises, and which, if it is in need of Irish votes, it must endeavour to conjure up. After so many 'final' land reforms, a movement for self-help had at last arisen in Ireland.

The Irish Chief Secretary knew well how to make use of all these tendencies. Like others, he had recognized that all future Irish landreform must take the shape of the promotion of land-purchase, and in the year I 902 he brought in a new land-purchase bill which however was soon withdrawn in favour of a better one.

Before the new Bill came into being, a surprising event occurred. At the instance of Captain Shawe-Taylor, a Conference of representatives of the landlords and the tenants had met in the Mansion House in Dublin, in order to discuss the foundations of a new agrarian law. ${ }^{1}$ The astonishment grew still greater when on the 3 rd of January, I903, the representatives of both

1 The representatives of the landlords were-Lord Dunraven, Lord Mayo, Col. IV. H. Hutcheson Poë, and Col. Nugent T. Everard; those of the tenants were the M.P.'s John Redmond, William O'Brien, T. W. Russell (for Ulster), and T. E. Harrington. Later on Captain Shawe-Taylor summoned, but unsuccessfully, a second Conference to solve the Irish University question. One may feel assured that he was in both cases merely an instrument of other powers, for the representatives of large groups of interests are not commonly 
parties signed a joint report to serve as the basis for the new Bill. The Report declared the purchase policy to be the only one possible. It was to be carried out in such a fashion that the yearly payments of the purchasing tenants should be 15 per cent. to 25 per cent. lower than second term rents. Also, evicted tenants who, as such, had no right to have judicial rents fixed, were to be permitted to purchase. The petty holdings were to be enlarged by dividing up the grazing lands. The landlords were to receive as their purchase money a sum which at 3 per cent. to $3 \frac{1}{4}$ per cent. interest would yield them as much as second-term rents, less not more than Io per cent. representing the difference between the gross rental and the net receipts. 'If the payments of the tenants were to be reduced by I 5 per cent. to 25 per cent., and the gross income of the landlord to be reduced by only io per cent. on the basis of 3 per cent. investments, it is clear that there must be a gap to be filled up. This gap was to be filled by the Treasury of the United Kingdom, by means of a bonus to be

ready to go into conference with their opponents on the initiative of well-meaning outsiders. It is supposed in many quarters that this institution of the extra-parliamentary, unofficial conference was brought by Sir Antony MacDonnell from India, where no Parliament exists.

[It may be commented on the above that the first of the extra-parliamentary conferences, the Recess Committee, took place before Sir Antony MacDonnell's Irish appointment.Transl.] 
accorded to the landlord in the interests of the pacification of Ireland. ${ }^{1}$

The Bill brought in by Wyndham in 1903 contained in point of fact all the provisions demanded by the Land Conference. It must not however be concluded from this that an impressionable statesman had simply waited on and complied with the public opinion of Ireland. It is far more probable that Mr. Wyndham had found ways and means to suggest to those who took part in the Conference both the necessity for that transaction and the results which it was desired to produce.

In any case, the Report made a deep impression in England. The Irish landlord and the Irish tenant were here for the first time at one, and they indicated a method whereby England could not fail to solve the Irish agrarian problem, if only she were magnanimous enough to pay the price of the reconciliation.

This price was the rock on which the Report, now embodied in a Bill, might have been wrecked; for $n o$ exception in point of principle could be taken to the other details of the measure, the parties immediately concerned appearing to be in full agreement about them. There remained, indeed, some hidden sources of friction. Neither the landlords in the Conference nor the repre-

1 "Report of a Conference held at the Mansion House, Dublin, I902-3;" "The Land Conference and its Critics," by W'm. O'Brien, M.P., 1904. 
sentatives of the tenants had had any official mandate. ${ }^{1}$ The Irish Parliamentary Party and the official association of the Irish landlords felt themselves, in a certain sense, set in the background; and in both organizations there were extreme elements who, on the one side, were not favourable to a continuance of the land-purchase policy, and on the other, hated all idea of a peaceful settlement, on the ground that it would make it more difficult to carry on the national agitation. Wyndham succeeded, with rare tact, in overcoming these difficulties. Even in Parliament he was able to commit Redmond and O'Brien so deeply to his Bill that the Irish Party can never rid themselves of their responsibility for the Act of $1903 .^{2}$

${ }^{1}[\mathrm{It}$ is true that the recognized Landlords' Convention refused to approve the project of the Conference, but a plebiscite taken among the Irish landlords in general accorded this approval by a sweeping majority. On the other side, an extraordinary proof of the completeness of the ascendency of the political over all other interests in Nationalist Ireland was given in the fact that in this Conference, where the fate of the Irish tenant farmers was to be decided, not a single tenant farmer had a voice.-Transl.]

${ }^{2}$ O'Brien has had to pay for his championship of the Conference programme by suffering a sort of political excommunication, pronounced against him by the Freeman's Journal, the chief organ of the Nationalist party. The indignation of the Freeman is quite intelligible. O'Brien was imprudent enough to declare his satisfaction with a measure of reform. For proposals relating to Ireland, it is regarded as axiomatic that beneficia obtruduntur. 
On the other hand, the members representing non-Irish constituencies, whose electors really had to meet the expenses, offered no opposition worth mentioning. Quite apart from the question of party discipline many of the Conservatives saw in the Irish colleagues who were likeminded with them on tariff questions, and whose help might be valuable if Chamberlain should compel the free trade Conservatives to withdraw. The Liberals had no interest in thwarting the Irish. As soon as a Conservative Government had carried through the dispossession of the landlords, then the weightiest argument against Home Rule-the avowed Liberal policy-would fall to the ground.

Thus the rôle of opposition to the scheme fell into the hands of certain purists in finance, whose objections the Chief Secretary met by pointing out that one could not pay too much for the reconciliation of Ireland: the financial sacrifices would soon be made good by the considerably reduced cost of the police employed by the Irish administration. The dream of an Irish millennium, by which most Irish administrations are at one time or another deluded, wrought its spell anew. In Dublin Castle sat a young Viceroy, full of sympathy with Ireland, whose guest King Edward was to be on his first royal visit to that country. Could one lay before a king, whose friendly inclinations towards Ireland were well known, a better offering than the acceptance of a bill which seemed at last 


\section{THE AGRARIAN REFORM OF 1903. I35}

to promise to Ireland the blessing of social peace?

Enough: the Act passed through both Houses of Parliament, and on the I4th of August, rgo3. received the royal assent. 


\section{CHAPTER IV.}

THE IVYNDHANI LAND ACT: ITS PROVISIONS.

The Wyndham Land Act was intended to bring about a voluntary transference of all the Irish land still in the hands of the landlords. For this purpose the Treasury may advance up to 100 millions sterling at $2 \frac{3}{4}$ per cent. interest with an additional $\frac{1}{2}$ per cent. sinking fund. The payment of the interest is secured upon the annual grants-in-aid given by the Imperial Treasury to the Irish County funds. These can be held back if payment is not made. The advances given to the tenants for the purpose of purchasing are made in cash. The tenants receive the advances from the Land Commission, within which a body consisting of three persons and named the Estates Commissioners has been formed for the purpose of carrying out the Act. The advance to any individual tenant is limited to $\ell_{5}, 000$, or in exceptional cases, $\ell_{7}, 000 .^{1}$

The Treasury procures the necessary funds by means of a loan at $2 \frac{3}{4}$ per cent. In order to guard against demoralizing the money market it bound itself not to issue more than five millions

${ }^{1}$ Formerly $£_{3}, 000$. 
a year for the first three years. If the issue is under par, then the Treasury must pay more than $2 \frac{3}{4}$ per cent. and there is therefore a deficit in the interest paid by the tenants, as this amounts to only $2 \frac{3}{4}$ per cent. This deficit is made up out of a fund of $£_{1} 85,000$ yearly, which is earmarked for Irish purposes. ${ }^{1}$

Repayment is made by the tenants by a yearly contribution to sinking fund, amounting to $\frac{1}{2}$ per cent. The tenant's total yearly payments therefore amount to $3 \frac{1}{4}$ per cent. By this low rate of sinking-fund payments the period of repayment

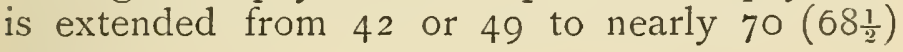
years.

The Estates Commissioners are bound to make an advance in all cases in which the total yearly payments of the tenant come to ro-40 per cent. less than his rent. If the rent is a first-term one, then the reduction on purchase must be at least

1 Of course this is only a form of words. In reality, the higher interest is made up out of Imperial funds, since this EI 85,000 is not separately raised from the Irish taxpayer. We have here the almost incredible fact that the credit of the Irish tenant is better than that of the English Government. When the $2 \frac{3}{4}$ per cent. loan stands at 90, the Treasury pays $\frac{1}{4}$ per cent. more than the tenant. At this quotation, the State must raise $£$ III, 000,000 in order to make its advance of $E_{100,000,000}$. The interest of the $\oint_{111,000,000}$ is, indeed, paid out of Irish funds, but the State is responsible for repayment of the capital. In January, 1905, moreover, the undertaking not to issue more than $£_{5}, 000,000$ sterling was modified on account of the low quotation, and $£ 6,000,000$ was issued. 
20 per cent., and cannot exceed 40 per cent. In the case of a second-term rent, the reduction must be between Io and 30 per cent.' The 'Zones' have made it possible to do away with a tedious investigation into the security offered by the holding for the advance and for safe-guarding the interests of the next heir. ${ }^{2}$ They have been vehemently attacked by the Irish Radicals as they form a limit to possible reductions. If a second-term rent amounts to $f \mathrm{Ioo}$, then the yearly payments of the purchasing tenant must be at least $f 70$, and cannot be more than 690 ; this on the basis of $3 \frac{1}{4}$ per cent. interest amounts to a maximum purchase price of $\$ 27694 \mathrm{~s} .7 \mathrm{~d}$., and a minimum of $£ 215317 \mathrm{~s}^{3} \mathrm{~A}$ landlord therefore cannot receive more than $27^{\circ} 7$, nor less than $2 \mathrm{I} \cdot 5$ times his second-term judicial rent. The capital value of a first-term rent varies between $24^{\circ} 5$ and 18.5 times the rent. ${ }^{4}$

A transaction in land-purchase is carried out by the whole body of the tenants on an estate agreeing with the landlord as to a purchase price,

${ }^{1}$ In the case of tenants who are not judicial tenants, a corresponding arrangement of rent has first to be undertaken.

${ }^{2}$ See pp. 93, 96.

3 Johnson, "Handbook of Land Purchase in Ireland," p. I5.

4 This would seem to make the new provisions much harder for the tenant than those of the Ashbourne Act, under which he usually paid only eighteen times the rent. But the rents under the Ashbourne Act were frequently not reduced rents, while a second term judicial rent represents a reduction of about 40 per cent. In order to pay $£ \mathbf{I}, 600$ under the 
and then applying to the Land Commission for an advance. It is not desirable that individual tenants should purchase separately; on the other hand an estate can under certain circumstances be sold piecemeal, since the Land Commission has the right to treat any part of an estate as an 'estate,' and to make an advance on it. It may also make an advance on untenanted land which is in the landlord's own hands and which is often the most valuable part of the property. Without this provision it would be difficult to get holdings for farmers who were outside the Land Acts, as, for instance, evicted tenants, or to enlarge petty holdings, two points on which the Land Conference laid much stress. Where the landlord and the tenant cannot agree on a purchase price, then the Land Commission is empowered to acquire the property, provided that three-fourths of the tenants (counting both by numbers and by value of holdings) have undertaken to purchase from the Commission on the terms approved by the latter. This provision makes it possible to carry out a sale even

Ashbourne Act the tenant had to pay $£ 64$ a year for 49 years. In order to pay $£ \mathrm{I}, 525$ under the Wyndham Act he pays $£ 49$ ris. 3d. for $68 \frac{1}{2}$ years. From the standpoint of the tenant the latter proceeding is the cheaper, although it becomes dearer by the prolonged hypothecation of the tenant's credit. In the first case, his total yearly instalments amount to $£_{3}, \mathrm{I}_{3} 6$; in the other, to $£_{3,733}$, without reckoning compound interest. Cp. also Fottrell, "The Irish Land Act. 1903, Explained," p. $3^{6 .}$ 
though a minority of the tenants is against it. The value of unsold land in the hands of the Commission must never exceed $f_{5}, 000,000$. The transaction is to be carried out without loss, except in the case of congested estates, where resale at a loss is permitted. ${ }^{1}$

Thus for the tenant the new Act implies a lessening of his obligations by 10 to 40 per cent., or to speak in his own language, a reduction of rent by from $2 \mathrm{~s}$. to $8 \mathrm{~s}$. in the $f$. The Act amounts simply and solely to this, that the Irish tenant can become owner of his holding by paying for $68 \frac{1}{2}$ years on an average 5 per cent. less than a present-day (I905) judicial rent would amount to. ${ }^{2}$

But whether the Irish tenant can take this bait or not depends partly on what inducements are offered to his landlord. The landlord receives for every $\delta$ Ioo of rent a principal sum of $\delta_{\mathrm{I}} \mathrm{S}_{5} \mathrm{O}-$ 2460 , or $f^{2}$ I $50-2770$, according to whether the rent is a first- or second-term one. Let us assume that he gets $£ 2,000$. That gives in trustee securities at $3 \frac{1}{4}$ per cent. an income of $£ 65$. He is

${ }^{1}$ It is possible to effect a sale outside the zones, but then come in all the arrangements involving delay, which the zone system was devised to get rid of.

2 A present-day rent would be a second-term rent, and the reduction on it would therefore be 10 to 30 , or say 15 per cent. $A$ rent of $f_{1}$ ioo therefore falls to $\mathcal{E}_{8}$. This $\mathcal{E} 8_{5}$ contains interest and sinking fund, about $\frac{2}{13}$, or say $\mathcal{E} \mathrm{r}_{3}$, being reckoned to sinking fund. The actual rent therefore is reduced from $£$ roo to $£ 72$, or by $2 S$ per cent. 
therefore poorer by $€ 35$ a year, a circumstance which is not an inducement to sell ; but for every $£ 100$ of rent he may count off about ro percent. for costs of collection; his net rent was therefore $£ 90$ and his loss is $£ 25$. Moreover he is once for all freed from the danger of further reductions in rent. If he sells at the present day he has even a considerable chance of gaining by a rise in the securities in which he invests. He has, moreover, yet other advantages. Parliament has devoted a sum of $£$ I 2,000,000 as a free gift for the Irish landlord. Upon every $£$ I oo of principal he gets f, 2 bonus. This bonus goes to the person in whose hands the estate is at the moment-it is his own private property and need not be invested in trustee securities. If the whole estate is sold for $£ 20,000$ the bonus will amount to $£ 2,400$, which at 4 per cent. will bring in $£ 96$ a year. On the $£ 2$, 000 estate the bonus will yield interest of $£ 9$ I 2 s., and the whole return from the proceeds of the sale will be $£ 74$ I2s. There will still be a loss of $£$ I $58 \mathrm{~s}$.

The landlord however is permitted to sell his residence and demesne, not to the tenants but to the Land Commission. He can afterwards buy them back from the Commission by means of an advance which they will make him, but which it must be observed may not exceed one-third of the total value of the estate. The landlord has never drawn rent from this demesne. But on an estate of the value of say $£ 20,000$ he has perhaps encumbrances amounting to some 
flo,ooo, for which he is paying interest at 5 per cent. For every $f \mathrm{I}, 000$ of net rental he therefore received only $£ 500$. Now let us suppose that he sells his residence with the estate and receives $£ 5,000$ for it. With this 65,000 he pays a part of his old debt and contracts a new one at $2 \frac{3}{4}$ per cent. interest; that is to say, instead of paying $£ 250$ interest he pays only $f 140$, thus saving $f$ I ro. If he uses another $f 5,000$ to clear off the remainder of his encumbrances, then his position is as follows:- He has now a capital of $\ell_{15}, 000$ and a debt of $£_{5}, 000$. The capital at $3 \frac{1}{4}$ per cent. will yield him an interest of

\begin{tabular}{|c|c|c|}
\hline Less & $\begin{array}{r}t_{4} 8_{7} \\
137\end{array}$ & $\begin{array}{l}\text { Io } \\
\text { I0 }\end{array}$ \\
\hline us the bo & $\begin{array}{r}35^{\circ} \\
96\end{array}$ & $\circ$ \\
\hline & $\succsim 446$ & \\
\hline
\end{tabular}

As against this, he had formerly,

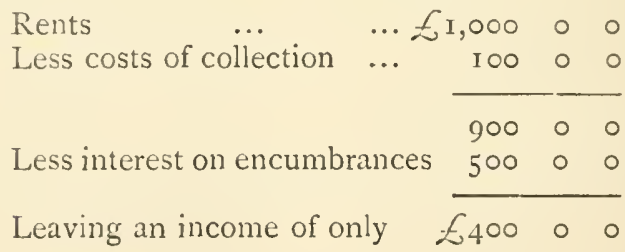

Thus, in the case of an estate encumbered to half its value, the new Act leads to a direct increase in the landlord's income. It is only the estates 
with no encumbrances, which are probably extremely rare, that will not bring any increase when sold. But under the new Act, the owner, if he wishes to sell, can by sale and repurchase of his demesne procure himself capital repayable in $68 \frac{1}{2}$ years at $2 \frac{3}{4}$ per cent. interest and $\frac{1}{2}$ per cent. sinking fund, available for any purpose he may desire.

In order to give efficacy to these attractions to sell, the modus operandi of purchase has been simplified. Anyone who has for six years enjoyed the rents of an estate has the right to sell it. ${ }^{1}$ In order to interest the existing possessor of the property-the tenant-for-life (for the Act makes no difference in the manner in which landed property is tied up)-in the sale, he receives the bonus as a free personal gift; it does not go into the family property. ${ }^{2}$ In the same way he also gets the arrears of rent up to one full year, or at most $5^{\circ} 4$ per cent. of the purchase money. ${ }^{3}$ The tenant-for-life thus receives 12 per cent. +5.4 per cent., or in all 17.4 per cent. of the purchase money, to do

1 That is to say, he need not, before negotiating, rummage anıng ancient archives in order to establish his ownership. These documents are only necessary in order to establish his claim to dispose of the purchase money, the interest of which he continues to receive as he formerly did the rents.

${ }^{2}$ This point was not made clear in the Act of 1903 , so that an amending Act became necessary (1904).

${ }^{3}$ If the purchase price amounts to 8.5 times the rent, then the arrears will be $\frac{1}{1} \overline{8}$, i.e., $5^{\circ} 4$ per cent. 
what he likes with. He can invest this sum as he chooses, and is therefore in a position to provide for his younger children. Thus he obtains a personal premium on selling. $\mathrm{He}$ is offered every inducement to seli, even though the process should result in a diminished income for the next heir.

From the standpoint of the landowner, the sale of his property takes the form of a great extinguishing of encumbrances, the possibility being offered to him of contracting a new mortgage at $2 \frac{3}{4}$ per cent., provided that it does not exceed, as we have seen, one-third of the total value of the estate. ${ }^{1}$ Thus, in the sale of a hundred millions worth of property the landowners who sell can mortgage thirty-three millions worth to the State at $2 \frac{3}{4}$ per cent.

In a country where interest at 5 per cent. is by no means uncommon, we are thus suddenly confronted with the introduction by the State of a mortgage interest of $2 \frac{3}{4}$ per cent. The mortgages owned by private persons are repaid; new investments of the kind are impossible, since the large estates will no longer exist; the rate of interest is artificially reduced. The advantages of this situation, in a country where the scope for placing capital is so narrow as in Ireland, seem to me doubtful. ${ }^{2}$

${ }^{1}$ Or $£ 20,000$ as a maximum in exceptional cases.

2 The mortgagees are in part institutions disposing of large capital, as, for instance, Insurance Societies. Ecclesiastical 
The Wyndham Act makes special provision for the solution of the problem of the enlargement of petty holdings. Where these holdings are merely converted into peasant proprietorships, the position of the occupier would be scarcely improved.

Hitherto the Congested Districts Board has occupied itself with the enlargement of holdings by the purchase of estates (containing untenanted as well as tenanted land) and their resale to the tenants. In future it can pursue this work more actively, since the Land Commission is to finance it. The Board however is confined to certain districts, even though similar conditions may prevail outside them. Here the Land Commission may come in. It may purchase "congested estates" and resell them to the tenants, even at a loss. Congested estates are defined to be those at least half of which is taken up by holdings of $\delta 5$ valuation or under, or which consists half of mountain or bog, or where $\frac{1}{4}$ or more is held in rundale.

The Land Commission may sell these estates to the tenants at a loss, but the total loss, taking into account both the cost price and the expenses of improvements, must not exceed ro per cent. of the sales carried out in that year.

bodies, too, have invested much of their funds in mortgages. The Protestant Church of Ireland, for example, is at the present moment collecting a fund of $£ 250,000$ simply to cover the worst of the loss that may arise through repayment of mortgages. For the man of small savings, the fall in the rate of interest is a very serious matter. 


\section{I46 THE IRISH AGRARIAN PROBLEM.}

Both the Land Commission and the Congested Districts Board may purchase untenanted land in order to use it for enlargement of holdings; and on these purchases too a bonus may be paid. By its power of deciding what is and what is not an estate the Commission can prevent a landlord from getting rid of his petty holdings and keeping the untenanted land. It will only sanction an advance where enough land can be obtained for the enlargement of any uneconomic holdings which may be included in the estate. 


\section{CHAPTER V.}

THE WYNDHAM LAND ACT IN OPERATION.

The Wyndham Act came into force on November Ist, I903.

Up to April 30th, 1904, there were sold under this Act I 22 estates, containing I,565 holdings, and having a total area of 74,884 acres. The purchase money amounted to $£ \mathrm{r}, \mathrm{r} 35,635$. The former rents came to $£ 48,297$. The average reduction is 25.8 per cent. The purchase price amounted to 22.9 times the rent.

Applications were received but not yet sanctioned for a further I45 estates, with 5, I93 holdings, at a purchase price of $£ 2,052,910$.

Of the farms sold, there were-

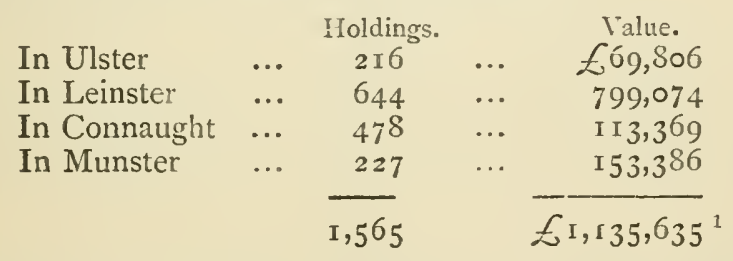

These figures show clearly that the Act is capable of bringing about purchases on a very extensive

[ ${ }^{1}$ On Jan. 31, 1906, the sales had amounted to $£ 7,207,548$. Transl.] 


\section{I4S THE IRISH AGRARIAN PROBLEM.}

scale. It worked best in Leinster, and worst in Ulster where the most competent farmers are, and in Connaught, where the worst poverty exists. This ratio is less distinctly but still perceptibly marked in the pending cases. ${ }^{1}$ Above all, we find that, in the Congested Districts, very few sales have taken place.

As yet, the Estates Commissioners have purchased no estate. Twenty-eight have been offered to them, and negotiations are proceeding in the case of twenty-six of these. They have bought 450 acres of untenanted land and established twenty-four evicted tenants on it. They are negotiating as to the purchase of 15,000 acres more.

It is already possible to conclude from these figures that a great part of the soil of Ireland will really change hands through the operation of the Wyndham Act. But even to-day it is also possible to affirm that the Wyndham Act will not be the last Irish Land Act. From various sides difficulties have been placed in the way of its success. The Ultras among the landlords have attempted to hold back their colleagues from selling, in order that higher prices may be obtained. So, too, the Radical section of the

${ }^{1}$ Applications :-

\begin{tabular}{|c|c|c|c|c|}
\hline Uls & & $\begin{array}{l}\text { Holdings } \\
\mathrm{I}, 520\end{array}$ & $\ldots$ & $\begin{array}{c}\text { Value. } \\
£_{441,480}\end{array}$ \\
\hline Le & $\ldots$ & 2,320 & $\ldots$ & $\mathrm{J}, \mathrm{I} S_{3,72}$ \\
\hline ght & & 721 & $\ldots$ & IOS, I 6 \\
\hline nster & & 632 & $\ldots$ & \\
\hline
\end{tabular}


Nationalists have warned the tenants against haste, in the first instance in order to get lower terms for them, but also from the old tactical ground, to hinder the solution of the land question. ${ }^{1}$

These difficulties are not insuperable. There will, however, always be a number of properties whose owners will decline to sell. These will be precisely those estates whose tenants pay their rents regularly and are not to be led into acts of disorder-that is to say, practically the Ulster tenantry. It may also be said that wherever there is an expectation of the rise of price in agricultural products, and where, therefore, the fear of further rent-reductions has disappeared, there the owner will have no monetary inducement to sell. All owners who are followers of the Chamberlain policy and who expect a golden age to dawn as a consequence of its success, would be fools to sell on a basis of reduced rents on the very eve of better times.

There are also many owners who are by no means inclined to sell their grazing pastures, which bring very high rents, at a price so low as to make it possible under reasonable conditions to

They even compelled William O'Brien to resign his seat; he was, however, re-elected. The policy of this Radical section amounts to this, that the price which the tenant is to pay is to be reduced by the amount of the bonus, which would thus be paid, not to the landlord but to the tenant. A very pretty arrangement-but it will not hasten the progress of land purchase. 
utilize them for the enlargement of holdings. Both the Congested Districts Board and the Estates Commissioners may indeed buy to sell again at a loss; but the amount of this loss is limited. Unless cottier tenants who are unable to make a living from the land are to be turned into peasant proprietors, the outlook for sales in the IVest is a narrow one.

There exist therefore large districts where the Act in spite of all the inducements it offers will not bring about voluntary sales. There the tenant must go on paying 25 per cent. more than his more fortunate neighbour; there also the old elements of agitation will continue to exist. We shall soon see the rise of a new agitation, whose watchword will be Compulsory Expropriation.

Where further difficulties of a more serious nature have not yet shown themselves, we must not conclude that they do not exist. Before the indebtedness of the tenants to the Government

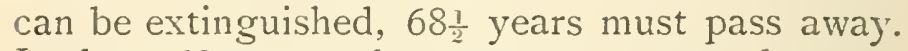
In these $68 \frac{1}{2}$ years the tenant must year by year pay the same rent, whether the times be good or bad. The danger attending this situation might very well have been diminished if the sinking fund had been fixed at a higher rate and the system of decadal reductions had been retained in order to make possible the reduction of the burden in the later stages.

It would then have been possible in years of distress to give appreciable remissions without entirely giving up the sinking fund. Of course. 
it would not in that case have been possible to effect sales at from $2 \mathrm{~s}$. to $8 \mathrm{~s}$. reduction in rent. Probably the rush to purchase on the part of the tenants would then have been less than it is. There is only the question whether this might not have been the more desirable result. In Ireland, the magic of property consists in the fact that it is cheaper by 25 per cent. to get it than not to get it. It is not the acquisition of property but the refusal of it that is associated with sacrifices. There are therefore a number of individuals who are forced into peasant proprietorship, a way of life in which they cannot get on, because they do not possess and cannot possess the qualifications, material or moral, which would fit them for it. The State will lose nothing by them, for their holdings are security for the advances. It is, however, a thoughtless application of the credit of the State when those who ought to benefit by it have to end in the bankruptcy court. Already under the Ashbourne Act cases of this unfittedness came to light not very unfrequently. ${ }^{1}$ Under the Wyndham Act, they will naturally be far more numerous.

The Irish tenant often has not sufficient capital to work his holding. The reduction in his rent will, indeed, make it easier for him to obtain working capital, especially as we have seen that the legislation which gave him a part ownership in his farm has facilitated this object, and

${ }^{1}$ Bailey's Report, pp. 8-I r. 
has substituted the bank as a source of capital for the usurer. Credit in Ireland has formerly been very dear -20 to 40 per cent. being not unusual. ${ }^{1}$

The Congested Districts Board, the Board of Public Works, and above all, in recent times, the Raiffeisen banks, have made personal credit cheaper. The new Act creates a broader basis for real credit, though not indeed an unlimited one, the farm being allowed to be mortgaged only to ten times the amount of the annual payment.

But the Irish farmer has no desire to borrow capital. He does not wish to increase his obligations. He will put more work into his farm, and will keep his standard of living as low as it was before. He is quite right to avoid new obligations, for they would narrow for him the margin between solvency and bankruptcy. The borrowing of working capital would endanger his existence, yet without it his success is impossible. There is nothing left for him then but to let his lands for grazing to wealthier neighbours. That has already happened under the Ashbourne Act, and it will happen in greater measure under the Wyndham Act. ${ }^{2}$ The very Act which was intended to divide up the grazing farms will create, in many cases, a class of peasantry whose existence can only be prolonged for a time by continuance of these grazing farms.

There is no possibility of excluding these

1 Bailey's Report, pp. I I, 24-26.

${ }^{2}$ Tb., pp. I, I 8, 19, 25. 
elements of weakness, for it is just these who most need the rent-reduction in the shape of which land purchase presents itself to them. One can assert with confidence that the Wyndham Act will at great expense create numerous peasant owners who will afterwards have to vacate their farms as independent proprietors. Yet no one in Ireland will declare openly for a system of economic differentiation in Irish life. A feeling for equality, albeit a very superficial kind of equality, comes into play in all agitation and is destined to bring many other dangers for the new agrarian order. The reductions of rent are different on different estates. The peasants who bought under the Ashbourne Acts are under different conditions from those who bought under the Wyndham Act. The obligations of the one will cease before those of the others. Second-term rents have been reduced by 2 I per cent., firstterm by 26 per cent. On one estate the rents are reduced by $2 \mathrm{~s}$. in the $f \mathrm{I}$, on another by $8 \mathrm{~s}$. Why these inequalities? Of course there are reasons which experts will recognize as decisive; but they will not console those who are on the unfavourable side of the difference. I do not believe that the English Government will ever have to meet anything like a great national strike against rent-it has only to withhold the grants in aid, and thus to starve out the local bodies-but local difficulties will always be occurring in Ireland so long as success and failure remain factors in the agricultural situation. 
It is just the creation by the Wyndham Act of weak elements in the social structure which will add to this danger. Already the agitator is asking with indignation why the starvation plots on the West of Ireland are to be capitalized at the same number of years' purchase as the large grazing farms of Leinster. From time to time local epidemics of bankruptcy will break out, and then to allay the local disturbances new agrarian legislation will be necessary.

Already a new agitation is making itself felt in the West, and is turning to account the failure of the potato crop in certain Western districts. Its cry is for partition of the grazing farms and enlargement of holdings. The Congested Districts Board has attempted to carry out this policy on some 44 estates and has done so with gratifying results, ${ }^{1}$ but in most of these cases it has had but a few holdings to deal with-only in the case of the Dillon estate of 4,500 holdings did it operate on a large scale. The experience of the Board goes to show that this enlargement of holdings is rarely practicable except when carried out at a loss; it is only practicable where untenanted land in sufficient quantities is available in the immediate neighbourhood, since all tenants object to being transplanted, and the inhabitants of the new district to which it is proposed to transplant them resist the proposal with all their might. Where the Board has succeeded they

${ }^{1}$ Twelfth Report, App. XXX. 
have to thank in part the tact of their officials, and in part, not the effect of the enlargement of holdings, but the remuneration which the tenants received for works of improvement carried out on their farms. ${ }^{1}$

Even if the Government were to pay down as a free gift from Imperial funds the whole cost of the enlargement of holdings, the difficulties would not then be at an end. The pasture-lands necessary for the purpose do not exist in overabundant measure. If one were to divide up among the farmers of the district all the cultivable land in the Union of Westport, each man would have only a I6-acre farm; in Belmullet, I5.5 acres; in Swinford, I4.5; in Dunfanaghy, I3.2. Every enlargement of a farm is a benefit to the owner of it, but as a social reform the process is of no value unless at least 20-acre farms can be provided. If such were to be formed in the above-mentioned districts, then transplantations to other counties and provinces would be necessary, and would assuredly call forth a fiercer resistance than Cromwell's transplantation of the Irish landowners to Connaught. If the enlargement process were to be carried

${ }^{1}$ The income of the C. D. B. for all purposes now amounts to $£ 86,000$ a year, but only a portion of this is available for the enlargement of holdings, the administration costs of which are very considerable. The loss of the Land Commission on the purchase and re-sale of congested estates must not by law be higher than to per cent. of the purchase price. 
out over all Ireland, and if all the large farms and demesnes were to be absorbed, then the Irish holdings as they exist to-day would only be brought up to just 30 acres. ${ }^{1}$

${ }^{1}$ No human being dreams, however, of the abolition of all the large farms. The average size of the farms so far purchased under the Wyndham Act is 47 acres. This Act permits the advance of $£ 5,000$, or even of $£ 7,000$, for the purchase of a single farm. That certainly does not point to the abolition of the large farms. Yet if these are to be retained, there is not much land left over in Ireland for the enlargement of the petty holdings, - all the less, as the evicted tenants hare to be provided for. 


\section{CHAPTER VI.}

\section{A PEASANT PROPRIETARY, AND AFTER.}

THE Wyndham Act will therefore on the one hand transform a great portion of Irish soil into peasant proprietorship; on the other, it will fail to abolish the petty farms and to create a class of purely economic holdings.

The Irish agrarian laws contain very strict regulations against the sub-division of the newly created holdings. Since the Act of 1881 , subletting and sub-division have been forbidden. ${ }^{1}$ In the case of a holding which would naturally be divided up in process of inheritance, the Land Commission can now have it sold for the benefit of the heirs, or can nominate an heir. ${ }^{2}$ Sub-letting is also forbidden, only a letting for a short term (con-acre) being permitted. Indebtedness is also provided against. Without permission from the Land Commission no tenant may mortgage his holding for more than ten times the amount of

${ }^{1}$ When a farm which is under a judicial rent has to be divided in the lifetime of the occupier, the Land Commission can order it to be sold.

${ }^{2}$ Section 54 ( $\left.\mathrm{r}\right)$. When an heir is nominated, the property is of course charged for the other parties interested. 


\section{I58 THE IRISH AGRARIAN PROBLEM.}

his annual payment. ${ }^{1}$ In principle, no exception can be taken to such provisions in Ireland. Since public money has been advanced for the artificial creation of a peasant proprietorship, it is also in the public interest to keep control over the execution of the measure. It is another question whether these regulations can really be carried out, and whether they are not treating symptoms rather than causes. Subdivision of farms in Ireland is not so much the consequence of laws of equal inheritance-it sprang rather from the fact that but for the soil a father had nothing which he could leave to his children.

This situation remains no better to-day. On the contrary, through the abolition of the great landed properties there will be lessened demand for labour. The demand for industrial labour, except in certain districts, has grown but little. When the younger children cannot get land they will migrate from the rural districts. This process is already going on. It has indeed gone so far that in many districts the large farmers suffer from want of labour. The labourer will not engage himself for the wages which they offer, particularly as the Irishman does not willingly take service with those of his own class. Thus lack of demand for labour and lack of supply run along on parallel lines. The result is an emigration from the country which robs it

${ }^{1}$ Section 54 (3) and (4). 
yearly of $35-40,000$ inhabitants. The more that the sub-division of farms (in its concealed ${ }^{1}$ as well as in its open forms) is checked, the more this emigration will be promoted. Now, if the farmer wishes to give assistance to those of his children who are emigrating, he must limit himself in the application of capital to his farm. The Irish peasant has never been accustomed to put his savings into the land-he has preferred the old stocking, or at best the bank. He has often in fact borrowed money at 5 per cent. from the bank when he had in it a deposit yielding at most I per cent. The causes of this attitude lay partly in the state of the agrarian laws, partly also in a well-grounded mistrust in his own capacity. In addition there was the need of providing for the younger children. The farmer will incur no new debts. He can, therefore, only do something for them by hoarding up his money in the bank, and giving it out to his children when they leave home. Thus he is compelled to continue his low standard of living -for his savings do not arise from a surplus of profits but from a deficiency of nourishment-and his want of capital becomes a chronic disease. Afterwards, as before, the whole family lives on the land, only that the departing children get their share in cash. No legislation can deal with

${ }^{1}$ As, for instance, when two small families dwell in one house, or a son builds on an addition to the house. 
this problem; at the bottom of it lies the fact that a farm which is burdened with interest on purchase money, and whose owner has neither working capital nor technical knowledge, can only show a surplus of profit under rarely favourable circumstances. Were the Irishman not capable of reducing his standard of living to the lowest possible point, the continued existence of numerous farmsteads in the country would be incomprehensible. But even this tenacity will prove inadequate to protect many of the newlyestablished farms against serious dangers. A rise in prices will of course afford some relief, just as the reductions in rent did. But the future of Ireland does not lie in agricultural tariffsit lies far more in the co-operative movement. Even if agricultural tariffs could effect in Ireland all that their champions claim for them, and effect it without any accompanying drawbacks, they would yet remain only one more link in the chain of legislative measures which are expected to bring about Ireland's welfare, without the active assistance of the Irishman himself.

For centuries the agrarian system of Ireland was indeed so regulated that the abandonment of all energetic effort seemed to be justified. The possibilities of success which are now open have not as yet set free the forces of the Irish people. The co-operative movement was the first attempt to organize these forces. This movement has in Ireland other problems to solve than it has elsewhere. In other countries, the 
State has banded together individuals in village communities of the most varying kinds, and these working in the framework of institutions of historic antiquity have undertaken the administration of matters of common interest-the communal forests, the pastures, the peat-bogs. In Ireland, all this organization was an affair of the estate, of the landlord or his agent. Now the landlord has disappeared. The Wyndham Act does indeed contain certain paragraphs, inserted at the instance of the co-operative leaders, which provide for the formation of grazing and turbary committees; but it has not substituted for the estate any system of communal agricultural organization. Thus none of the forms of agricultural organization are in existence, except what rest on voluntary cooperative enterprise. The significance of the cooperative movement for Ireland therefore does not lie in the fact that it cheapens production and improves quality. It lies in the fact that through it the erstwhile tenant, now left to himself as a peasant proprietor, gets a backing and an agricultural education-that it opens a way in which the now slowly beginning educational activity of the State can reach him. On the success of this work of agricultural education will depend the measure of success to be achieved by the Irish agrarian reform of the past ten years.

This reform, in spite of the criticisms which I have applied to it, has been an absolutely 
necessary one. As a product of the fierce political strife which followed upon the neglect of centuries-a strife in which political power and not social reform was the main object-it has been now hurried, now belated in its execution. The vanity of the statesman who would see Ireland pacified in his four years' term of office, and the calculations of the tactician who feared to drop from his hand the weapon of agrarian agitation, have had more influence on it than has the zeal of the true reformer. Irish nationalism has utilized the agrarian war of classes to win the Irish people for the national idea. It has succeeded. It has defeated and finally expropriated the most influential section of the former English colonists of Ireland-the landed gentry. The Wyndham Act has essentially rounded off this process. Through this agrarian war the national question became for a time a class question. Now, when the Irish tenants have had conditions assured to them more favourable than any other tenantry in the world enjoy, the national question must lose this colouring. The bought-out landlord remains in his residence which he has mortgaged to the State at $2 \frac{3}{4}$ per cent. He has no further cause of friction with his former tenants, who now pay him no rent. He no longer regards himself as part of an English garrison. He will again become an Irish patriot. He no longer talks of the unity of the Empire-for Home Rule has few terrors for him now. He talks of 'Devolution'-of 
the concession of a kind of self-government for Ireland. He will struggle for a while against the designation 'Home Rule,' because not so long ago he was declaring that he would die in the last ditch for the union of the three kingdoms; but he will soon be reconciled to it. It will not be very long till all the former landlords whose chief interests lie in Ireland have become enthusiastic nationalists. ${ }^{1}$ It is indeed possible that the agrarian peace now beginning-a peace which, however, will still for a time be broken by occasional combats-may be rendered fruitless by sectarian dissensions. In any case it may still be said that the most serious obstacle to the granting of Home Rule to Ireland has been removed.

When the Irish people, who have during the past thirty years seen so many of their wishes fulfilled, have seen also the realization of this last dream, then they will gradually come to

${ }^{1}$ It is very significant that Lord Dunraven, the strongest personality among the participants in the Land Conference, should last autumn have developed a scheme of Devolution. It is also not without interest that he has at the same time taken a strong interest in the agitation for Fiscal Reform insti tuted by Chamberlain. Irish politicians are always instinctively Protectionists. If at the present time certain protective proposals came to the benefit of the peasantry, and they let themselves be won over by Chamberlainism, that would mean the winning of 80 votes for Protection. However, as long as the Conservatives refuse Home Rule to Ireland, and the Liberals are for granting it, Irish sentiment will incline to the Liberal and Free-Trade side. 
I64 THE IRISH AGRARIAN PROBLEM.

understand that injurious legislation and governmental oppression may indeed be a check to progress; but that the mere removal of bad laws is not enough to make a people great and strong. 


\section{N D E X.}

Achill Island, 54.

Act (Land) of 1870,74 sqq.

Act (Land) of $188 \mathbf{1}, 82$ sqq., 8\%, 157.

Act (Land) of I 891,86 sqq.

Act (Land Purchase) of 1885 , 94 sqq.

Act (Land Purchase) of 1887 and 1888, 96, 97 .

Act (Land Purchase) of I89I, 97 sqq.

Act (Land Purchase) of 1896,98 $s q q$., how far successful, I 7 sqq.

Act (Land Purchase) of 1903, I32 $s q q$. (see 'Wyndham Act').

Act (Local Government), 9, 125, 126.

Administration of justice, cost of, Io.

Ages of population in Ireland, 17.

Agrarian crimes, $11,72,76,80$.

Agriculture in Ireland, $32 \mathrm{sqq}$.; 'extensive' technique, 38, 44; industries subsidiary to, 53,54 ; defects of, 38, 58, 69 .

America, money remittances from, 55,69 ; Irish movement in, 73 , 77 ; competition from, 76 ; growing friendliness to England, 125. Archiv fïr Sozialwissenschaft, $2 n$. Ardara, 55 .

Area of Ireland, 32 .

Armagh, 45 .

Arrears Act, 84.

Arrears of purchase money for holdings, I 7 .

Ashbourne Acts, 94-97.

Balfour, Arthur, I22, 123.

Balfour, Gerald, 122,125 .

Barley, 42.

Belfast, 8, 29, 30.

Belmullet, 47,48 , 155 .

Bessborough Commission, 81, 82.

Birth statistics, 17 .

Board of Works, 152.
Bonn, M. J., I sqq.

Boycotting, 79, $124 n$.

Brewing industry, 29.

Bright, John, 72, 73, 74, 92, 93.

Burke, Thomas, $8 \mathbf{I}$.

Butt, Isaac, 77 .

Buttermaking, 39 .

Capital, not put into land, $57,159$.

Carrick (Donegal), 55 .

Castle, the, 9.

Cattle in Ireland, 32, 33, 38, 39, $40,4 I, 56,91$.

Cavendish, Lord F., 8I.

Chamberlain, J., 80, I24, I34, I49, $163 n$.

Clifden, 48 .

Clothing industry, 28.

Compensation for improvements, etc., 7 I, 74, 75 .

Compulsory expropriation, I 20 , I5O.

'Con-acre,' 90, 157.

Conference of landlords and tenants, 130 sqq.

Congested Districts and C. D. Board, $50 \mathrm{sqq}$.; food of people in, 53 ; estates purchased for re-salc by Board, 64, I $45,150,154$, I $55 \mathrm{n}$.; influence of Board on agricultural credit, 152 .

Conquest of Ireland, 59 .

Co-operative movement in Ireland, 4 ; its foundation, 129 sqq.; future of Ireland lies in, 160 ; its significance for Ireland, I6 I.

Cork Industrial Conference, 28.

Corn duties, effect of, 37 .

Cowper Commission, 86.

Coyne, IV. P., $27 n$., $36 n$.

Credit, agricultural, I52, I59.

Crime in Ireland (see 'Agrarian crimes').

Cromwell, colonization under, 59 .

Crops in Ireland, 32 sqq.; doubtful statistics of, $35 n$.; fodder, $3^{8}$. 
Dairying, co-operative, etc., 39 .

Davitt, Michael, 77, 79, I 8 .

Death statistics of Ireland, $\mathbf{I} 7$.

Deficit farms, Pt. I., ch. vi., passim.

De Freyne estate, I I9.

Department of Agriculture, $\mathbf{1} 29$.

Devolution, 163 .

Devon Commission, 66.

Devoy, John, 77.

Dillon estate, 64, I19, 154.

Distillery industry, 29.

Donegal, 48, 55 .

Dual ownership, $64,8_{3}$.

Dudley, Lord (Viceroy), 134.

Dunfanaghy, 48 , I 55 .

Dumaven, Lord, $163 n$.

H. M. Edward VII., I23, 134.

'Eleven montlus system,' 4I, 90, 9 I.

Emigration from Ireland, 16, 17, $158,159$.

Encumbered Estates Court, 60.

English Boards in Ireland, 10.

Englished-managed estates, 67 .

Enlargement of holdings, 47, I 54-6.

Estates Commissioners, 136.

Evictions, 7 I, 76, 8I, 89, I 16.

Fair rent, 82, 106.

Farmers in Ireland, defective methods among, $38,5^{8}$; low standard of living, 23, 160 (see 'A griculture' and 'Peasant Proprietors.'

Farms in Ireland, varieties of, 35-43; size of, $44 s q q$. ; household farms, 43 ; consolidation of, 47 ; valuation, 48; un-economic below 615,49 ; deficit farms, 55, 56; sub-division of, 57 ; equipment of farms, how provided, 63 ; modes of tenure, 66 sqq. ; want of capital for, I 59 .

Fenianism in Ireland, $73,78,86$.

Financial Relations Commission, I $28 n$.

Fisheries, 29, 54.

Forster, W. E., 80.

Fry Commission, $106 \mathrm{sqq.}$
Gaelic League, I4.

George, Henry, il 8.

Giffen, Sir R., I9.

Gladstone, IV. E., 85, 96.

Grazing-farms, 36, 38, 39, 40, 83 , $120,152,154$.

Griffith's Valuation, 68.

Guinness's Brewery, 29.

Gweedore, I 10.

Hicks-Beach, M. E., I24.

Holdings, see 'Farms.'

Home Rule movement, 77, 96, 122, I 26, I34 ; probable effect of Land Acts on, 162 sqq.

Homespun weaving, 55 .

Household farms, 43 .

Housing conditions in Ireland, 2I $s q q$.

Illegitimacy in Ireland, I 8.

Illiteracy in Ireland, 15.

Imperialism, meaning of, 15 .

Improvements, tenants', compensation for, $71,74,75$.

Incomes in Ireland, 19, 20.

Intransigeant party, I I, I2.

Invincibles, the, $8 \mathrm{I}$.

Ireland, not reconciled to England, $\vec{j}, 8$; but probably not irreconcilable, 9; how administered, 9, 10; agrarian crimes in, II, 72, 76, 80; Volunteer system not extended to, I2 ; England's economic failure in, I3 sqq. ; religions in, I3, 23 ; language, 14 ; percentage of illiteracy, I5; population statistics, $16 s q q$.; a poor country, 19 $s q q$.; housing conditions $\mathrm{in,} \mathbf{2} \mathbf{1}$, 23; social life in small towns, 24,25 ; occupations of the people, 26 sqq.; an agrarian country, 3 I, 57 ; area of, 32 ; nature of agriculture in, $32 \mathrm{sqq}$. ; climate, 37; growth of pasture in, 37 ; tillage 'extensive,' $3^{8}$; classification of farms, 39 sqq.; a land or small farms, 44 sqq.; recent prosperity affecting limited class, 47 ; 
congested districts in, 50 sqq.; land of large estates, 59 ; classification of estates, 60,61 ; modern forms of temure in, 66 sqq. ; new plan of land question in, 77 sqq. ; beginning of reform, 85 ; peasant proprietary declared for, 94 ; two main types of farmers in, IO4; policy of conciliation adopted by Conservatives, I22; Plunkett's policy of self-help, I27; temporary union of classes, I30; IVyndham Act passed, I 35 ; drawbacks to full success of Act, 148 sqq.; insuperable obstacles to enlargement of holdings, 154 , 155,156 ; co-operation the only solution of economic problem, 160,161 ; legislative reforms not alone sufficient for prosperity, 164.

Irish language, I 4 .

Irish Church, 74, 92.

Irish Parliamentary Party, 8, 84 ; I22, 133 .

Judges in Ireland, 10, I I.

Juries in Ireland, I I.

Kelp-burning, 55 .

"Killing Home Rule with kindness," 122.

' Kilmainham Treaty,' $8 \mathbf{I}$.

Labourers, position of, under Act of 1881, 89 ; under Purchase Acts, 158 .

Land Acts (see ' Acts ').

Land Agents, 64, 65 .

Land Courts, effect on agrarian situation, $105 \mathrm{~s} q q$.

Landed Estates Court, 6o, 68.

Landed property, its tenure, 6 I sqq. ; mortgages on, 62 .

Land League, 79 sqq.

Landlords in Ireland, origin of their estates, 59, 63; effects of famine on, 60 ; absentee and others, 60 ; mortgages on property of, 63 ; residence a centre of consumption not administration, 64 ; characteristics of the class, 65 ; commanding position of, prior to 1881, 69 ; mistalies of, 82 ; position under Land Acts, pt. III., ch. i., passim; position under Lanel Purchase Acts, 102 sqq. ; 'a wiser man,' I25, 126 ; conference with tenants' representatives, 130; position under IVyudhan Act, I $40 s q q$. ; in the future Ireland, I $62 s q q$.

Land Stock, 98, 104.

Land tenure in Ireland, forms of, $66 s q q$.

'Lazy-beds,' 38, 5 I .

Licences, publicans', jo.

Limited liability companies, 2 I.

MacDonnell, Sir A., I3 1 .

'Magic of property' in Ireland, I 19, I 5 I.

Manchester School, ;2.

Marriage statistics, I8.

Mayo, 54.

Migratory labour, 54 .

Milk production, 33 .

Mining industry, 29.

Moore, George, 18.

Mortgages on land, 62, 157.

Munster, colonization of, 59 .

Nationalization of land, championed by Davitt, 77 ; opposed by Nationalist party, 94, I I 8.

O'Brien, William, 86, I33, $149 n$.

Occupations of Irish people, 26, sqq. ; 35 .

Parliament, scenes in, 9 .

Parnell, C., 78, 79,85, 95, 118,125 .

I'asture farming in Ireland, $36-41$.

Patterson, Sir R. L., 28.

Peasant proprietors, 6o, 73 sqq. $8_{3}$; Acts for establishing, 92 sqq., I 36 sqq.; social character of, 117 ; persons unqualified to be, 151 ; often aided by wages, I I $n$., 155 ; results of want of capital and education, I59, I60. 
'Plan of Cainpaign,' 86.

Plantations of Ireland, 59 .

Plunkett, Sir IIorace, his policy of co-operation, $\mathrm{I} 2 \%$; forms committee from all classes, 127 ; shows combination practicable, 128; co-operative movement, and Department of Agriculture, 129: ' a movement of self-help,' 130.

I'opulation statistics, $16 \mathrm{sqq}$.

Potatocs, $34,35^{12}, 43,5^{1}$ : failure of, in 1886,85 .

'Poteen,' 30.

Prices of agricultural producc, 75, $76,85,86$.

Protection policy, $163 n$.

Protestantism in Ireland, 13; in towns, $23,24$.

Purcliase clauses in Act of 18\%0, 74,75 .

Raifleisen bauks, I52.

Railways in Ireland, 27, 28.

Recess Committec, 127 .

Redmond, John, 133 .

Rent, 43, 68, 69, 75, 88; experiment of judicial, $105 \mathrm{sqq}$.

Revolutionary movement, $11,77,85$.

Ritchie, C. T., 124.

Roman Catholics in Ireland, number of, I3; edncational statistics, 15 , I6; in towns, 23.

Roscommon, sheep in, 42 .

Royal Irish Constabulary, 10.

Rural industries, 53, 54, 69.

Russell, T. W., $12 \mathrm{I}$.

Savings Banks, 20.

Scaweed as manure, 52.

Settled Estates Act, 62.

Shawe-Taylor, Captain, 130.

Slieep in Ireland, 42.

Ship-building industry, 29, 30 .

Soils of Ireland, 36 .

Sondan, the, 8.

Sovcreign, British, the, 9.

Stall-fecding, 39 .

Standard of living in Ircland, 23 , I60.

Sub-division of farms, 57, I57-I 59 .
Sul-letting, 157 .

'Suin,' the, 52 .

Swine in Ireland, 33, $+2,43$.

Swinford, 155.

Taff Vale case, $12+n$.

Tallow case, $120,124 n$.

Tariffs, $163 n$.; future of Ireland not in, 160 .

Tenant-Riglit, 69, 70, 74, 110,116 2 .

Textilc industry, 28 .

'Three F's,' the, 泣, 82, 83 .

Towns in Ireland, 19, 23, 24, 68 .

Transvaal IVar, II, 125.

Trevelyan, Sir G., 95.

Trustee securities, interest on, 62 .

Tumip question, the Irish question a, 5,35 .

Ulster, a colonial scttlement, 7,8 , 59 ; towns in, 24 ; lincn industry, 28 ; agriculture, 42 ; land of small holdings, 48; agrarian movement in, 86,121 ; peasant owners in, I1 8 .

Ulster Tenant-Right, ${ }_{0}$, $7 \mathrm{O}, 74$, I I 6 n.

Underlinen industry, 29.

United Irish League, 1 20, 124.

University Question, $130 n$.

Valuation of holdings, $48 \mathrm{sqq}$.

Volunteer system, not extended to Ireland, 12.

Westport, 48, 155 .

Woollen industry, 28.

Wyndham, George, I23, 132, 133.

Wyndham Act, 130; Irish Party responsible for, J33; adopted, 135 ; provisions of, 136 sqq.; its meaning to the tenant, 140 ; to the landlord, 140 sqq.; results, 147 sqq. ; not the last Irish Land Act, 148, 154; compared with the Ashbourne Acts, 153; limited formation of communal organization under, 161; an absolutely necessary reform, I61, I62 ; rounds of process of abolition of landlordism, I62. 

UNIVERSITY OF CALIFORNIA LIBRARY

Los Angeles

This book is DUE on the last date stamped below.

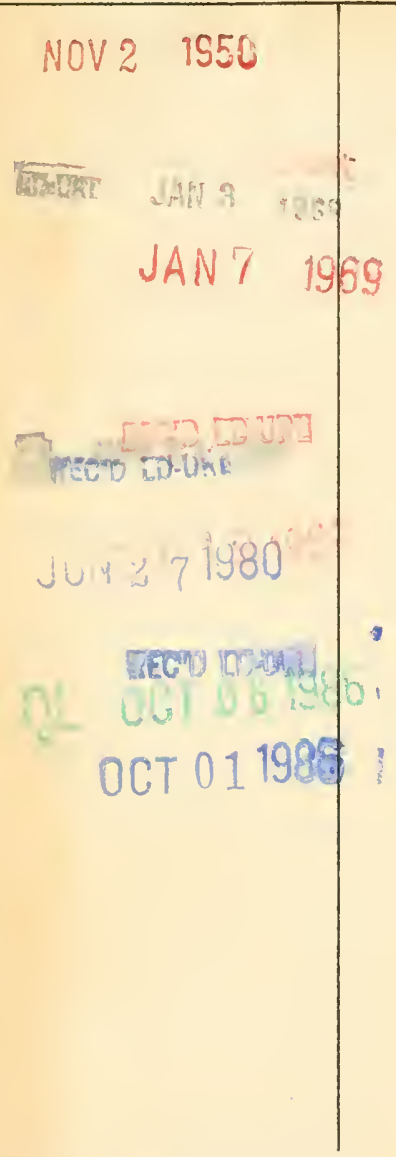

Form L9-25m-9,'47(A5618)444

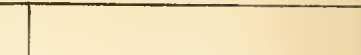




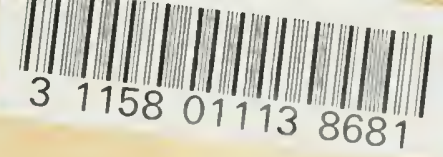

UC SOUTHERN REGIONAL LIBRARY FACILITY

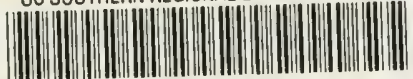
AA $001108096 \quad 7$ 


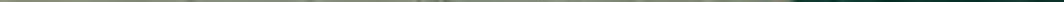

